UNIVERSIDADE DE SÃO PAULO

FACULDADE DE FILOSOFIA, LETRAS E CIÊNCIAS HUMANAS

DEPARTAMENTO DE HISTORIA

PROGRAMA DE PÓS-GRADUAÇÃO EM HISTÓRIA SOCIAL

ROGER DOMENECH COLACIOS

A produção científica em energias alternativas no Estado de São Paulo - o caso do PIPGE/USP (1992 a 2002)

São Paulo

2009 
ROGER DOMENECH COLACIOS

\section{A produção científica em energias alternativas no Estado de São Paulo - o caso do PIPGE/USP (1992 a 2002)}

Dissertação apresentada ao Programa de Pós-Graduação em História Social do Departamento de História da Faculdade de Filosofia, Letras e Ciências Humanas da Universidade de São Paulo para a obtenção do título de Mestre em História.

Área de Concentração: História Social

Orientadora: Profa. Dra. Maria Amélia Mascarenhas Dantes

São Paulo

2009 
ROGER DOMENECH COLACIOS

\section{A produção científica em energias alternativas no Estado de São Paulo - o caso do PIPGE/USP (1992 a 2002)}

Dissertação apresentada ao Programa de Pós-Graduação em História Social do Departamento de História da Faculdade de Filosofia, Letras e Ciências Humanas da Universidade de São Paulo para a obtenção do título de Mestre em História.

Aprovado em:

Banca Examinadora

Prof. Dr.

Instituição: Assinatura:

Prof. Dr.

Instituição: Assinatura:

Prof. Dr.

Instituição: Assinatura: 
Para a pequena $G i$. 


\section{AGRADECIMENTOS}

Meus sinceros agradecimentos à Professora Maria Amélia Mascarenhas Dantes pela orientação, conselhos, observações, correções, críticas, incentivos, puxadas de orelhas, oportunidades e questionamentos, me guiando por entre os labirintos que formam a pesquisa e a própria vida.

Ao longo da pesquisa pude contar também com a participação de mestres que sempre estiveram dispostos a me aconselhar, debater idéias, colocar nos eixos minhas confusões e problemas, especialmente Cláudia Eliane Parreiras Marques Martinez, pelo instinto organizador que nunca consegui copiar, Paulo Henrique Martinez, por não deixar o "boteco fechar", e a Jozimar Paes de Almeida, por ensinar a caçar carne humana na história. À Márcia Regina de Barros Silva pelos conselhos e que por várias vezes em simpósios sempre colocava uma dúvida e dava esclarecimentos para os meus problemas e interpretações. Ao Francisco de Assis Queiróz, que por tantas vezes sentou comigo e me ouviu falar da pesquisa. À Miriam Hermeto, nas nossas andanças pelos museus de São Paulo e nas conversas sobre os hábitos paulistanos. Também ao Janes Jorge pelas opiniões e sugestões sobre o tema desta dissertação.

Ao auxílio das bibliotecárias da Biblioteca Prof. Afonso Telles do Instituto de Eletrotécnica e Energia (IEE/USP) e também à Coordenação de Aperfeiçoamento de Pessoal de Nível Superior (CAPES) e ao Departamento de História da FFLCH/USP pela bolsa de estudos, sem a qual não teria sido possível a realização desta pesquisa.

Dizem que mesmo quando se está só sempre irá encontrar amigos para dividir a solidão, ainda mais numa pesquisa de pós-graduação, quando você se vê em meio a pilhas de documentos, textos, livros, poeira e silêncio. Encontrei estes amigos e eles dividiram comigo opiniões, perspectivas, angústias e com isto formando grandes laços 
de amizade e barulho. Agradeço a Pablo Spíndola, Mariana Dantas, Carla Berto, Vitor Henriques, Guillaume de Saes, Lidiane Soares Rodrigues e Fabíula Sevilha. Todos sem exceções me provocaram e foram por mim provocados...

Não posso me esquecer daqueles que sempre me apoiaram. Minha família, com a dedicação que me permitiu trilhar este caminho árduo e difícil. Meu pai Joaquin Domenech Colacios, espanhol teimoso; minha vó Dona Maria e meu tio Zé Luis, que sempre me carregaram quando eu precisava. A Gislaine Gomédi, futura esposa, pelo carinho, atenção e compreensão, por tudo que passamos. E as minhas duas "anjas" da guarda que sempre olham por mim. 
"O historiador não é aquele que sabe. É aquele que busca. E que portanto questiona as soluções prontas, que revê, quando necessário, os velhos processos. Quando necessário? - não equivale isto a dizer sempre?" (Lucien Febvre)

"A energia é algo necessário para que uma coisa viva possa ser capaz de 'fazer um esfôrço', mas ela também tem um significado mais amplo." (Isaac Asimov) 


\section{RESUMO}

O mote desta pesquisa é a análise da produção científica sobre energias alternativas no Estado de São Paulo entre os anos de 1992 a 2002. Especificamente, realizou-se o estudo de caso do Programa Interunidades de Pós-graduação em Energia (PIPGE) da Universidade de São Paulo, que desenvolveu estudos em energia solar e biomassa da cana-de-açúcar. A pesquisa utiliza como fontes históricas a literatura científica produzida pelos pesquisadores do Programa, tais como as teses e dissertações, artigos e "papers" e a documentação institucional referente à estrutura e objetivos do PIPGE. No período recortado para análise ocorre uma série de eventos sobre meio ambiente e desenvolvimento que levam em conta a questão das energias alternativas, criando cenários políticos e científicos para a pesquisa e desenvolvimento dessas tecnologias. Já a opção pelo Estado de São Paulo se justifica por ter sido o maior consumidor e produtor de energia do país na década de 1990, representando um espaço que necessitava aumentar o parque gerador de energia para poder suprir a demanda de seus habitantes.

Palavras-chave: Energias Alternativas, História da Ciência, Literatura Científica, Programa de Pesquisas, Estado de São Paulo. 


\begin{abstract}
This research aims at analyzing the scientific literature on alternative power resources in São Paulo State from 1992 to 2002. A case study of the Interdisciplinary PostGraduation Program in Energy of São Paulo State University (PIPGE/USP) was accomplished since the Program developed studies on solar energy and sugar cane biomass during the period under study. Historical sources comprise the scientific literature produced by the researchers of the Program such as theses, dissertations, articles and papers, and the institutional documentation of the Program with respect to its structure and objectives. In the period under study, a series of events on environment and development occurred that considered the issue of alternative power resources, producing political and scientific settings for research and development of such technologies. São Paulo State was chosen because it was both the largest energy consumer and producer of the country in the $90 \mathrm{~s}$, thus representing the need for augmenting energy generation in order to supply the inhabitants' demands.
\end{abstract}

Key words: Alternative Power Resources; History of Science, Scientific Literature, Scientific Program, São Paulo State. 


\section{SUMÁRIO}

\section{Dedicatória}

\section{Agradecimentos}

\section{Resumo}

\section{Abstract}

Introdução

Capítulo 1 - O conceito de energia: ciências e sociedade 33

Energias: cotidiano e trabalho 34

Formação da matriz energética mundial e brasileira 42

Conferências da ONU e as energias alternativas pós-1973 57

Capítulo 2 - Produção, criação e argumentação: construindo 82 enunciados no PIPGE

O PIPGE: uma proposta interdisciplinar $\quad 83$

Discurso científico no PIPGE: autores, leitores, direções, $\quad 94$ tecnologia e política

1. Autores e autorias: estabelecendo hierarquias cientificas 96 no PIPGE

2. Em busca de leitores e informações 99

3. Larga e pequena escala: diferentes objetivos no PIPGE 112 para as fontes alternativas

4. As tecnologias em energias alternativas: energia solar e 125 biomassa de cana

Capítulo 3 - Cornucópia energética: história, progresso e desenvolvimento sustentável

História e progresso: o passado da biomassa e o

Fontes 


\section{INTRODUÇÃO}

Procurei compreender a pesquisa e desenvolvimento de energias alternativas no Estado de São Paulo, no período de 1992 a 2002. Uma proposta que apresentava enquanto problemática a análise da produção literária dos cientistas em comparação com o contexto político estadual e nacional nestes anos. Também procurei estabelecer uma relação entre argumentação e aplicação social, dos enunciados que os cientistas pretendiam inserir na sociedade, definindo, dessa maneira, as redes que envolvem o caráter político e científico dos atores e objetos envolvidos na temática.

A energia, enquanto um conceito de amplo entendimento, limitada à temática, fontes alternativas, necessitava de um recorte espacial e temporal que me permitisse ser possível realizar a síntese das informações, fatos e dados, sem perder de vista a história em suas escalas diferenciadas, a macro e a micro-análise. Neste sentido, o conceito de energias alternativas foi analisado em diversas dimensões respeitando, contudo, certos limites para não extrapolar a tênue linha que divide quantidade e qualidade, daquele, que ao abordar tudo, acaba não alcançando nada.

Para o recorte espacial, o Estado de São Paulo se encaixou na proposta por ter sido (e ainda é) significativo ao contexto nacional na utilização de fontes energéticas durante o período recortado. Este espaço também é simbólico da importância que as formas alternativas de energia adquiriram nas discussões estratégicas das nações ao redor do mundo, e não menos no Brasil. Pois o Estado de São Paulo foi o maior consumidor de energia durante a década de 1990 e também um dos maiores produtores de energia do Brasil. Portanto, demonstrou que poderia ser o recorte espacial no âmbito 
da micro-escala, o que possibilitaria a compreensão da pesquisa e do desenvolvimento de fontes alternativas dentro daquilo que era pretendido na problemática do mestrado.

O tema me permitiu analisar uma quantidade imensa de fontes documentais, livros e artigo, que jorravam aos borbotões por todos os lados em que adentrava na investigação. As fontes propiciaram a compreensão de maneira satisfatória da temática escolhida. Mais além, a documentação e a bibliografia permitiram a escolha de diversos caminhos, diversos sentidos, diversos métodos e diversos olhares.

Com o enfoque a produção científica, busquei grupos de pesquisa que atuassem na área de energias alternativas no Estado de São Paulo, que deveriam ter sido criados dentro dos anos recortados, 1992 a 2002 . Este levantamento de informações também se revelou profícuo, com aproximadamente 16 grupos enquadrados dentro da problemática da pesquisa. Novamente, as fontes jorraram, pois os cientistas se mostraram bastante produtivos, com uma literatura substancial que não permitiria a análise num período de tempo viável para a conclusão do trabalho. A solução foi a busca por um grupo que servisse de síntese e de exemplo para a atuação dos cientistas de São Paulo na pesquisa das fontes alternativas.

Um estudo de caso foi a resposta para conseguir delimitar a documentação e qualificar a análise. O Programa Interunidades de Pós-graduação em Energia da Universidade de São Paulo (PIPGE/USP) foi o grupo escolhido para tal finalidade. As exigências da seleção deste foram: Representatividade, enquanto um grupo que fosse significativo para o Estado de São Paulo e também nacionalmente; o PIPGE inclusive mostrou uma abrangência internacional; Produtividade, procurando neste quesito uma quantidade documental que permitisse compreender as estruturas e o conjunto de atuação destes cientistas; Atividade, devendo ser cientistas que estivessem em constante trabalho, tanto nos "laboratórios" quanto em "campo"; Qualidade, apesar de ser um 
quesito subjetivo, é o resultado dos outros; quer dizer, foi determinado pela abrangência de atuação, inserido neste a sua produção; Relevância, não somente quanto à temática, mas como grupo que tivesse a pretensão de contribuir com o setor energético estadual ou nacional, posicionando-se politicamente na sua literatura, fazendo do jogo político e científico conceitos presentes no cotidiano de suas atividades. O PIPGE atendia a estes quesitos, e mais, o acesso às fontes (teses, dissertações, artigos, papers e documentação do Programa) não se apresentou enquanto um problema e estas fontes respondiam às questões levantadas com riqueza de informações e significados.

O Programa Interunidades de Pós-graduação em Energia, criado em 1989, na Universidade de São Paulo, procurava unificar quatro áreas de pesquisa: a eletrotécnica/energia, a engenharia, a economia e a física. Concentrava-se em quatro linhas de pesquisa: 1) Análise Econômica Institucional de Sistemas Energéticos; 2) Energia, Meio Ambiente e Sociedade; 3) Fontes Renováveis e não Convencionais de Energia; 4) Planejamento Integrado de Recursos ${ }^{1}$. Atualmente conta com mais uma área de investigação: Redes Elétricas, Equipamentos e Qualidade de Energia. ${ }^{2}$ Dessa forma, contempla em vários aspectos um dos setores fundamentais na área estrutural e estratégica para a soberania de um país, o energético.

O PIPGE, fundado pelo então reitor José Goldemberg (físico que tem uma atuação em pesquisas sobre energia e foi Secretário Estadual desta pasta), procurava participar nos processos decisórios sobre o tema, principalmente no que se refere ao planejamento energético, além de desenvolver pesquisas tecnológicas. O Programa alcançou renome internacional, trazendo pesquisadores e financiamentos estrangeiros para seus laboratórios e salas de aula e acompanhou, inclusive, as mudanças durante a reestruturação do setor energético nacional entre os anos de 1990 e 1997, quando se deu

\footnotetext{
${ }^{1}$ CAPES. Relatório INTERUNIDADES EM ENERGIA / USP (NRD6) - 1998.

${ }^{2}$ CAPES. Relatório INTERUNIDADES EM ENERGIA / USP (NRD6) - 2005.
} 
a venda da maioria das empresas estatais para o capital privado, provocando a abertura do mercado energético para a livre concorrência e possíveis investimentos na expansão do parque gerador de eletricidade, de interesse direto de alguns pesquisadores do Programa, principalmente aqueles que procuravam introduzir as fontes alternativas de energia. Além disso, conta na área de alternativas energéticas, com o Centro Nacional de Referência em Biomassa (CENBIO), criado em 1996, e o Laboratório de Energia Fotovoltaica (LSF), do ano de 1995.

A pesquisa do mestrado se desenvolveu com a análise dos materiais disponíveis sobre o PIPGE na Biblioteca Prof. Fonseca Telles do Instituto de Eletrotécnica e Energia da Universidade de São Paulo (IEE/USP). Tal espaço conta com um amplo acervo de teses e dissertações defendidas, além de conter de maneira sistemática as produções literárias dos docentes e discentes que compunham os quadros do Programa. Na biblioteca também foi possível o acesso a documentos governamentais, tais como as matrizes e balanços energéticos estaduais e nacionais, além de bibliografias, manuais técnicos, revistas e periódicos sobre o tema.

Busquei também informações e documentação na secretaria do Programa, obtendo resoluções, quadro de disciplinas oferecidas, relações de palestras e eventos promovidos. Pretendi realizar entrevistas com os docentes e pesquisadores do PIPGE, afim de conseguir informações sobre a criação do Programa, motivações e objetivos que os levavam a trabalhar com fontes alternativas de energias. Entretanto, houve um silêncio vindo de um lugar de onde não esperava que pudesse vir. Calados ficaram, de certa maneira, já que seus trabalhos falaram por eles em determinados momentos, os cientistas, cujas entrevistas poderiam ter somado ao processo de análise da temática, ressalva feita ao Professor Dr. Murilo Fagá, que se dispôs a conversar e esclarecer alguns pontos obscuros da pesquisa. 
Em sequência, a pesquisa procurou na bibliografia os marcos temporais em relação aos estudos e discussões sobre energias alternativas no Brasil e exterior, como também sobre a formação da matriz energética nacional na década de 1970. Estes marcos são considerados fundamentais aqui para a compreensão dos rumos tomados e diretrizes legadas à temática proposta. Somente com tais pontos definidos, as fontes do PIPGE foram analisadas, pois assim poderiam ser enxergadas a partir de um contexto histórico estabelecido.

Com base no levantamento das fontes e da bibliografia, defini a periodização, sendo os séculos XIX e XX os marcos temporais amplos, pois englobam os processos de modificação social, econômica e política do conceito de energia, caracterizando quando esta se torna uma mercadoria fundamental para as sociedades modernas. Especificamente, determinei os anos de 1992 a 2002 como balizas cronológicas principais para a dissertação, pois nesse período teremos eventos que foram significativos para a temática, sendo eles de três ordens: 1) Internacional: ocorreram em 1992 e 2002 as duas principais Conferências da ONU que ressaltavam os cenários científicos para a pesquisa em energias alternativas; 2) Política: entre o início dos anos 1990 e 1997 aconteceu a reestruturação energética do Brasil e entre 1998 e 2002 teremos as consequências imediatas dessas mudanças institucionais para a geração elétrica no país; 3) Discursiva: nos textos dos pesquisadores do PIPGE, houve mudanças estruturais e argumentativas ao adaptarem o discurso, sobre as energias alternativas que pesquisavam, ao contexto que se apresentava.

Quanto à discussão historiográfica, percebo haver uma lacuna na historiografia sobre o tema energia. Poucos autores se dedicaram a pesquisar esta área, seja política, científica ou economicamente, apenas fazendo referências à forma com ela foi utilizada no meio social. Teremos, comumente, estudos históricos que se referem ao tema, 
inserindo-o dentro de um contexto de análise maior, tal como os trabalhos de Eric J. Hobsbawm "A era do capital" e "A era dos extremos", em que retrata as fontes energéticas em uso nesses períodos ou então acontecimentos relacionados a elas no século XVIII/XIX e o XX, respectivamente, não focando o tema como protagonista da análise. ${ }^{3} \mathrm{O}$ mesmo ocorre com Fernand Braudel em "Civilização Material, Economia e Capitalismo".

Lacuna maior pode ser verificada na historiografia em relação às energias alternativas, sobre cujo tema teremos um número reduzido de trabalhos. Ressalvas são as obras de Jozimar Paes de Almeida, "A extinção do arco-íris", de 1988, e mais recentemente, em 2008, "O óleo filosofal", enquanto trabalhos historiográficos que buscam analisar as energias alternativas. O primeiro livro tem como objeto a produção de álcool no Estado de São Paulo durante a década de 1980; já o segundo se refere ao biodiesel no contexto do desenvolvimento sustentável do século XXI.

Além destas referências, utilizei autores que dão enfoques diferenciados ao tema energia, constituindo-se em sua maioria de especialistas na área, sendo que uns estão voltados para a economia, outros para a política energética.

A metodologia de trabalho baseou-se em três pontos: historicidade dos conceitos, análise dos discursos e argumentos da produção científica e, por fim, o exame sobre o conjunto de idéias presentes nos estudos sobre energias alternativas. Tais pontos foram abordados em todos os capítulos da dissertação, servindo de apoio à interpretação das fontes documentais e da bibliografia sobre a temática.

\section{Historicidade dos Conceitos}

\footnotetext{
${ }^{3}$ Cf. HOBSBAWM, Eric J. A era do capital. Rio de Janeiro: Paz e Terra, 1996; HOBSBAWM, Eric J. A era das revoluções: 1789 - 1848. São Paulo: Ed. Paz e Terra, 2000.

${ }^{4}$ Cf. BRAUDEL, Fernand. Civilização material, economia e capitalismo, séculos XV-XVIII. São Paulo: Martins Fontes. (3 volumes), 1995.
} 
A energia apresenta funções sociais específicas, que ultrapassam os limites da propriedade exclusivamente econômica e interferem em questões de lazer e no cotidiano das pessoas. Um conceito que se tornava mais amplo que o até então compreendido pela ciência. Como veremos, o desenvolvimento de uma conceituação tanto social quanto científica para o termo energia serve de base para a compreensão do processo de materialização da mesma no seio das sociedades ocidentais. A historicidade dos conceitos, considerada importante por Koselleck para a História Social, permite que sejam mapeadas as implicações que levaram determinado termo a ter um significado específico.

[...] O método da história dos conceitos é uma condição sine qua non para as questões da história social exatamente porque os termos que mantiveram significado estável não são, por si mesmos, um indício suficiente da manutenção do mesmo estado de coisas do ponto de vista da história dos fatos; por outro lado, fatos cuja alteração se dá lentamente, a longo prazo, podem ser compreendidos por meio de expressões bastante variadas [...]. ${ }^{5}$

Assim como, para Koselleck, a historicidade de um conceito está ligada às possibilidades de entendimento em vários âmbitos da realidade histórica:

[...] A identificação do nível de generalização sobre o qual se está trabalhando - e isso diz respeito a toda história social que investigue duração, tendências e prazos - só pode ser conseguida com a reflexão sobre os conceitos ali empregados, que por sua vez auxiliam a identificar, do ponto de vista teórico, a relação cronológica entre o acontecimento e a estrutura, ou a justaposição de permanência e alteração. ${ }^{6}$

As diversas características que compõem um conceito o tornam passível de ser estudado por historiadores. É certo que Koselleck chega a propor que seja criada uma disciplina histórica somente para que se dê conta desse tipo de pesquisa, uma disciplina que seria somada à História Social. Não pretendo seguir à risca o que propõe o autor,

\footnotetext{
${ }^{5}$ KOSELLECK, Reinhart. Futuro passado: contribuição à semântica dos tempos históricos. Rio de Janeiro: Contraponto/PUC Rio, 2006. p. 114.

${ }^{6}$ Idem. p. 117.
} 
mas apenas traçar as mudanças e permanências sociais do conceito de energia, extrapolando as temporalidades definidas para este estudo quando necessário.

Dessa maneira, podemos compreender quais ações contribuíram para mudanças do conceito de energia ao longo do século XIX e do XX. Períodos históricos marcados pela busca por novas fontes energéticas e pelo desenvolvimento de técnicas que mais bem utilizassem a energia em processos industriais e sociais. Um contexto em que o petróleo inseria-se gradualmente na vida européia e do ocidente em vias de industrialização, e a eletricidade aparecia de forma lenta nas grandes cidades, acontecimentos que simbolizavam o progresso e a vida moderna, como força propulsora dos novos tempos que viriam com o século $\mathrm{XX}$.

Este levantamento, baseado nas propostas de Koselleck, serve como apoio para a compreensão dos demais capítulos. A diferença no trato do conceito de energia terá influência nas pesquisas científicas do Programa Interunidades de Pós-Graduação em Energia da Universidade de São Paulo (PIPGE/USP), assim como nas questões políticas envolvidas, como as propostas governamentais para o setor energético, tanto do Estado de São Paulo, quanto do Governo Federal brasileiro.

\section{A Produção de Discursos Científicos}

A literatura científica é um espaço de criação, argumentação e concretização, em que os cientistas abordam o mundo a sua volta e buscam interpretá-lo, reconhecê-lo e projetar sua imaginação. Neste sentido, as ciências se constroem como fruto da criação, pensamento e inquietações dos cientistas. Suas verdades, enunciados e discursos produzem uma literatura sui generis, mas que, segundo Isabelle Stengers, é baseada nos mesmos objetivos da ficção científica: cativar seus leitores.

A invenção primeira das ciências modernas, aquela das ciências experimentais, exigiu um estilo de paixão que fez do autor científico um híbrido singular, entre juiz e poeta. O cientista-poeta "cria" seu objeto, "fabrica" uma realidade que não existia tal e qual no mundo, 
mas que pertence antes à ordem da ficção. O cientista-juiz deve conseguir que se admita que a realidade que ele produziu é capaz de prestar um testemunho fidedigno, isto é, que sua fabricação pode aspirar à condição de simples depuração, eliminação de parasitas, encenação prática das categorias segundo as quais convém interrogar o objeto $[\ldots]^{7}$

Estabelecer um fato, publicar uma verdade, é uma prática que possibilita aos cientistas fecharem sobre um enunciado o ciclo de trabalho, a que, às vezes por anos ou até mesmo décadas, se dedicaram ao analisar um determinado objeto. Um trabalho de observação, compreensão e criação sobre os dados obtidos. Momento em que é estabelecido um juízo sobre a própria pesquisa, ao determinar seus dados e definir suas conclusões.

A construção de um enunciado torna-se um detalhe a mais na constituição das ciências modernas, representando a abordagem política do cientista, que até então estaria obscurecida pelo laboratório, e que neste momento emerge aos olhos da sociedade. Realça também uma questão fundamental: a presença de uma dicotomia entre o lado de dentro e o de fora dos laboratórios. Enquanto nestes ocorreriam as atividades puras da ciência, do outro lado das paredes, no mundo real, tais práticas seriam dadas de outra forma, criando-se toda uma "alegoria" a respeito do que se passa nestes espaços. Bruno Latour considera esta divisão menos uma questão mística e mais mundana de se compreender

[...] A maioria das dificuldades associadas à ciência e tecnologia vem da Idéia de que existe um tempo em que inovações estão nos laboratórios, e outro tempo quando estes tentam um novo conjunto de condições que irão invalidar ou autenticar a eficiência dessas inovações. Este é o "adequatio rei et intellectus" que tanto fascina os epistemologistas $[\ldots] .^{8}$

\footnotetext{
${ }^{7}$ STENGERS, Isabelle. A invenção das ciências modernas. São Paulo: Editora 34, 2002. p. 201.

8 “"...] Most of the difficulties associated with science and technology come from the Idea that there is a time when innovations are in laboratories, and another time when they tried out in a new set of conditions which invalidate or verify the efficacy of these innovations. This is the 'adequatio rei et intellectus' that fascinates epistemologists so much [...]." LATOUR, Bruno. Give me a laboratory and I will raise the world. IN: KNORR-CETINA, Karin D. \& MULKAY, Michael. Science Observed: perspectives on the social study of science. London: Sage Publications, s/d. p. 155 (SIC).
} 
Definindo as ciências e cientistas enquanto enredados por fios e linhas que os ligam por vários ângulos e posições, formando redes que atuam sobre a prática desses atores, destaca-se a abordagem política, que teria, enquanto função, a de ampliar as redes de atuação do cientista, indo buscar na sociedade seja a confirmação da veracidade de seus enunciados ou a continuidade de suas pesquisas mediante financiamentos, apoio dos governos ou da própria comunidade científica. Para Isabelle Stengers, o que também está em jogo seria a demarcação de um espaço no qual as ciências se singularizam em relação ao restante da sociedade. Dessa maneira, possibilita também marcar o perímetro daquilo que pode ser considerado como ciência e também não-ciência. Ou seja, "[...] a distinção entre aqueles que têm o direito de intervir nos debates científicos, de propor critérios, prioridades, questões, e aqueles que não têm esse direito [...]." 9 , de modo a evitar que as discussões científicas, sobre o método, teoria, pesquisa ou objeto, se tornem um debate aberto a todos, e para Stengers, principalmente,

[...] Reconhecer uma dimensão política constitutiva das ciências é, antes de tudo, compreender por que o conflito entre as ciências e seus interpretes é previsível, assim que estes últimos comecem a julgar, ou seja relativizar, a distinção entre ciência e não-ciência [...]. ${ }^{10}$

Portanto, cria-se uma "batalha" entre propositores de fatos ou enunciados científicos e aqueles que se propõem a testar a veracidade da informação. Ou seja, $a$ priori, dentro da perspectiva do cientista, como afirma Thomas Kuhn "[...] A ciência normal, atividade na qual a maioria dos cientistas emprega inevitavelmente quase todo seu tempo, é baseada no pressuposto de que a comunidade cientifica sabe como o mundo é [...]". ${ }^{11}$ Este saber sobre o mundo é um saber construído sobre a base da controvérsia acadêmica, entre os próprios cientistas, assim " [...] A competição entre

\footnotetext{
${ }^{9}$ STENGERS, Isabelle. Op. cit. 2002. , p. 82.

${ }^{10}$ Idem. p. 82.

${ }^{11}$ KUHN, Thomas. A estrutura das revoluções científicas. São Paulo: Perspectiva, 2006. p. 24.
} 
segmentos da comunidade científica é o único processo histórico que realmente resulta na rejeição de uma teoria ou na adoção de outra [...]." ${ }^{12}$ Esses fatos não se aplicam somente a especialistas no mesmo paradigma, mas também junto a grupos que podem ser considerados como "rivais" na determinação de um mesmo enunciado: "[...] Para ser aceita como paradigma, uma teoria deve parecer melhor que suas competidoras, mas não precisa (e de fato isso nunca acontece) explicar todos os fatos com os quais pode ser confrontada.", 13

Entretanto, ao contrário de Kuhn, Isabelle Stengers entende que as desavenças dentro ou fora de um paradigma, e todo o sentido político que aí se encontra, vão muito além da comunidade científica. Para ela, discutir o que são ciências e o que não são, qual a teoria ou fato é o verdadeiro, irá atingir também aos atores fora do laboratório, de fora do núcleo da prática das ciências. População leiga, políticos, agências financiadoras, burocratas, capital privado são alvos que invariavelmente serão buscados na concretização dos fatos científicos e também serão fundamentais na decisão sobre qual grupo será vencedor da disputa.

Entendo que existem duas frentes de batalha estabelecidas: uma interna junto à comunidade científica e outra, externa, que atua diretamente naqueles que influenciam a pesquisa, a financiam ou a adotam em seu cotidiano.

$\mathrm{Na}$ construção dos fatos das ciências, pode-se dizer, assim como Bruno Latour o faz, que ocorre a utilização de táticas e estratégias para que um lado ultrapasse as controvérsias que possam surgir. Tais elementos constitutivos do todo que formam as ciências, ou seja, o fator científico e o político, social, cuja mescla compõe o quadro

\footnotetext{
${ }^{12}$ Idem. p. 27.

${ }^{13}$ Ibidem. p. 38.
} 
sobre um cientista, devem ser levados em conta na análise do enunciado em discussão. ${ }^{14}$ Neste sentido, conforme aponta o autor, a literatura produzida por estes atores se constitui em "espaço" privilegiado de ação das ciências, pois representa uma atividade científica-política dos cientistas na concretização de seus enunciados.

\section{Ciência, Abundância e Sociedade}

Se considerarmos que a energia é hoje parte constante na vida e nos caminhos do ser humano, que se tornou dependente de sua presença nos diversos ambientes que compõem a sua existência, somos levados a entender que um ciclo se fecha sobre as sociedades no mundo ocidental do século XX.

Em um lado do ciclo, a produção, distribuição e o consumo representam o elemento tecnológico, ou seja, maquinário para a produção, fios e postes para a distribuição e equipamentos consumidores. Do outro, temos a matéria-prima, eficiência e recorrência da energia, que constituem os elementos naturais, tal como o sol, carvão, biomassa, gás natural, enquanto produtos que devem apresentar taxas de eficiência na conversão e de recorrência no meio natural suficientes para a utilização pelas sociedades.

Esta relação entre energia e sociedades apresentaria um contraponto, direcionado para o segundo lado do ciclo, o elemento natural. A procedência das matérias-primas energéticas na natureza é variada, tanto na eficiência de conversão como nas probabilidades de serem encontradas, ou seja, grande parte das fontes de energia de que as sociedades modernas fazem uso é de incidência escassa na natureza e, portanto, passível de serem esgotadas suas reservas. Evidentemente que tal informação é referente

\footnotetext{
${ }^{14}$ Cf. LATOUR, Bruno. A esperança de Pandora: ensaios sobre a realidade dos estudos científicos. Bauru: EDUSC, 2001; LATOUR, Bruno. Ciência em ação: como seguir cientistas e engenheiros sociedade afora. São Paulo: Editora UNESP, 2000; LATOUR, Bruno. Joliot: a história e a física misturadas. In: SERRES, Michel (Dir.) Elementos para uma História das Ciências. Lisboa: Terramar, 2003; LATOUR, Bruno e WOOLGAR, Steve. A vida de laboratório: a produção de fatos científicos. Rio de Janeiro: Relume Dumará, 1997.
} 
às principais matérias-primas energéticas utilizadas atualmente, de origem fóssil: o petróleo, o gás natural e o carvão, ou então minerais utilizados em usinas nucleares, tal como o urânio, cuja extração está localizada em minas e reservas em algumas partes do planeta, e que invariavelmente irão acabar a médio e longo prazos, não podendo ser consideradas como fontes energéticas seguras e presentes no futuro da humanidade. Neste quesito, a década de 1970 foi significativa, pois demonstrou à grande parte das nações ao redor do mundo que as fontes principais da matriz energética seriam passíveis de esgotamento, gerando uma crise generalizada nos países importadores dos derivados do petróleo. Portanto, se tornava necessária a busca por fontes que substituíssem estas matérias-primas, surgindo o conceito de energias alternativas, mas estas teriam um bônus ao trazerem a possibilidade de produção em caráter renovável, ou seja, não se esgotariam.

Esta busca pelo renovável se traduziu, durante parte dos anos 1980 e ao longo da década seguinte, no conceito de desenvolvimento sustentável e, atualmente, no ideal de sustentabilidade das sociedades humanas frente às crises ambientais, poluições e a escassez de recursos naturais para a manutenção dos índices de progresso econômico apresentados por algumas nações e almejados por outras. As ciências e a tecnologia deveriam ser capazes de prover de fontes renováveis um mundo ávido de energia para seu funcionamento, e encontrariam na natureza a abundância, a fartura em fontes que estariam em constante processo de recuperação, tal como o sol, os ventos, as plantas, marés e o calor proveniente das profundezas do planeta. Metaforicamente, uma "Cornucópia Energética"15, que alimentaria uma "Cocanha", um mundo imaginário em que a natureza proveria abastadamente seus habitantes. Evidentemente que a "Cocanha"

\footnotetext{
${ }^{15}$ Cornucópia faz parte da mitologia grega, simbolizado por um chifre de cujo interior emanam frutas e doces, representando a abundância. Este objeto teria sido um chifre de Amalthea, uma cabra, que após ter sido quebrado por Zeus, se tornou mágico, e o animal, unicórnio. Cf. Dicionário Enciclopédico Koogan, Larousse, Seleções. Rio de Janeiro: Editora Larousse do Brasil Ltda, 1982. Vol. 1.
} 
trata de um mito medieval, exposto por Hilário Franco Jr. como proveniente da atmosfera encontrada na época de escassez de alimentos, sendo que a fome teria um lugar de destaque nos versos que compõem o mito; além disso, roupas, bebidas e certa libertinagem seriam as características do lugar. Os homens e as mulheres que habitariam esta terra fantástica estariam livres inclusive do envelhecimento, bebendo na fonte da juventude que lhes legaria a eternidade. ${ }^{16}$ Entretanto, a idéia se torna significativa para a argumentação que se segue, quando percebemos, assim como o faz Le Goff, no prefácio da obra de Franco Jr., que

[...] A abundância responde à vontade de se opor à realidade vivida $\mathrm{e}$ sofrida por dupla insatisfação alimentar, de um lado decorrência de uma produção ainda limitada pela natureza e por um progresso econômico que não eliminaria inteiramente a carência e mesmo a fome $[\ldots] .{ }^{17}$

Se trocarmos alimentos por energia, podemos facilmente caracterizar a mesma "realidade vivida e sofrida" da atualidade sem, no entanto, reduzir toda a conjuntura que nos envolve sob a ótica energética. Se ainda temos fome e sede, carências das mais diversas, em última análise, buscamos energia em todos os sentidos de nossas vidas. $\mathrm{E}$ iremos buscar na natureza as respostas para estas necessidades; alimentos e água formas de energia que mantêm em funcionamento as atividades intrínsecas ao ser humano - e as fontes energéticas de maneira geral - aquelas responsáveis pelos combustíveis e pela eletricidade do cotidiano das sociedades - são elementos procurados na natureza, e, assim como escreveu Le Goff sobre a "Cocanha", também são frutos de limitações naturais. A “cornucópia” traria a satisfação energética para as sociedades de forma inesgotável; estando nas fontes renováveis ou alternativas a materialidade deste conceito, presentes no meio natural, devem ser aproveitadas pelo ser humano,

\footnotetext{
16 "A fonte da juventude/ Que rejuvenesce as pessoas,/ E traz outros benefícios./ Lá não haverá, bem o sei,/ Homem tão velho ou tão encarnecido." FRANCO JR. Hilário. Cocanha: a história de um país imaginário. São Paulo: Companhia das Letras, 1998. p. 33.

${ }^{17}$ LE GOFF, Jacques. Prefácio. In : FRANCO JR. Hilário. Cocanha: a história de um país imaginário. São Paulo: Companhia das Letras, 1998. p. 3.
} 
principalmente ao substituir as fontes não-renováveis de origem fóssil. Neste sentido, como afirma Cornelius Castoriadis:

Toda sociedade cria um conjunto de necessidades para seus membros e lhes ensina que a vida não vale a pena ser vivida e mesmo não pode ser materialmente vivida a não ser que estas necessidades sejam bem ou mal "satisfeitas" [...]. ${ }^{18}$

Assim, o anseio por energia enquanto alimento para as sociedades modernas serve de resposta à "fome" contemporânea de objetos e bens materiais que representam o estilo de vida, principalmente das nações ocidentais, considerado ideal, ou seja, presente no conjunto das necessidades pelo que valeria a pena viver. Fornecer energia em seus variados formatos de forma abundante implica diretamente os possíveis caminhos seguidos pela ciência e tecnologia em busca pela "cornucópia" na natureza. Uma imagem que adequaria o discurso científico à materialidade natural, servindo esta última como foco para o olhar científico, ferramentas, métodos e experiências, enquadrando a necessidade social ao usufruto irrestrito dos recursos provenientes da natureza, sendo mediados pelos enunciados proferidos pelas ciências.

Recorrer à natureza para prover as sociedades foi um dos objetivos das ciências desde pelo menos o período moderno, com a divisão entre social e natural, e o proclamado jugo humano sobre o mundo selvagem. Conhecer o meio natural era uma das ferramentas dos seres humanos para conquistar o progresso material e social como um aspecto significativo para os pensadores e cientistas do período. No mundo contemporâneo, não deixaram de seguir este projeto moderno: ainda fazem a divisão entre as esferas, levando o cientista a procurar na natureza seus objetos de estudo, mas agora intensificado pelo fator econômico que irá determinar sua pesquisa e seu trabalho como um todo.

\footnotetext{
${ }^{18}$ CASTORIADIS, C. \& COHN-BENDIT, D. Da ecologia a autonomia. São Paulo, Ed. Brasiliense, 1981. p. 20.
} 
Esta divisão entre sociedade e natureza seria intermediada pelos estudos científicos, agindo, dessa maneira, como a síntese entre os opostos. Entretanto, este papel ideal legado às ciências teria um modus operandi diferenciado, atuando na adequação do mundo natural às perguntas científicas. Para Kuhn, a ciência normal, ou seja, aquela que já se concretizou sobre um paradigma, acabaria por envolver a natureza dentro de suas teorias e métodos, ficando evidente para o autor que seria "[...] uma tentativa de forçar a natureza a encaixar-se dentro dos limites preestabelecidos $e$ relativamente inflexíveis fornecidos pelo paradigma [...]." ${ }^{19}$ Portanto, será o paradigma que irá definir as bases para a compreensão do que determinado grupo de cientistas terá da natureza. Componentes teóricos, que serão de fundamental importância para a imagem que os cientistas criam de si mesmos, ou seja, permeada de sentido e verdade, encontrando o respaldo de seus enunciados na natureza, sendo esta mesma um fruto de suas indagações e respostas. Assim, ciências e cientistas formariam a relação entre ator e competências que focam objetivamente o mundo natural e permitiriam chegar à advertência nos dada por Stengers, de que:

[...] A imagem que eles criam, em termos filosóficos, de uma conduta científica objetiva dirigindo-se a um mundo submetido a suas exigências, não teria qualquer pertinência se ela não tivesse encontrado um grande número de protagonistas, pouco interessados na filosofia, mas muito interessados nas vantagens da etiqueta de cientificidade fornecida pela semelhança com essa imagem [...]. ${ }^{20}$

A objetividade, alcançada com a presença de uma materialidade que pode ser concebida tal qual a necessidade das ciências, cria o campo de atuação e a imagem de uma etiqueta da cientificidade; ou seja, a natureza produzida pelas ciências possibilita a prática dos cientistas, a formulação de teorias e fatos, isto é, a caracterização da ciência em si mesma. Se há uma artificialidade no conceito de natureza oriundo das ciências,

\footnotetext{
${ }^{19}$ KUHN, Thomas. Op. cit. p. 44.

${ }^{20}$ STENGERS, Isabelle. Op. cit. p. 31.
} 
talvez esta seja resultado também da criação de uma idéia de natureza anterior, ou seja, socialmente construída. "[...] A idéia de natureza nunca foi pensada, mas somente oposta a uma certa quantidade de fatos, atitudes e acontecimentos que ferem a sensibilidade de alguns homens [...]", ${ }^{21}$ afirma Clément Rosset sobre a natureza, ou então, podemos encontrar esta indicação de uma natureza criada em Carlos Walter Porto Gonçalves e Serge Moscovici, respectivamente: "O conceito de natureza não é natura.l" ${ }^{22}$ e "A natureza é dupla, cindida: original por seu fundamento, artificial pelas circunstâncias [...]." ${ }^{23}$ A natureza se torna objeto de um conhecimento funcional, onde seu valor para a humanidade é apenas para seu progresso científico e econômico, portanto, perde sua identidade com a vida e as relações de sobrevivência. Para Adorno e Horkheimer, essa natureza é desqualificada de sua originalidade e: "[...] torna-se o material caótico de uma simples classificação e o si-mesmo todo-poderoso converte-se em mero ter, em identidade abstrata [...]. "24 Identidade abstrata nos meios sociais e paralelamente em meios científicos; uma abstração que pode ser definida como objetiva, apta a se moldar ao olhar do cientista em sua busca pelos fatos contidos neste material decifrável.

Ao mesmo tempo, se não houvesse o outro lado do fator, ou seja, a sociedade, tal ciência não teria condições de manter-se, renovar-se e desenvolver-se dentro dos processos produtivos e da lógica de funcionamento na qual está inserida. Alterando a própria realidade dos cientistas, dependendo das perspectivas que as teorias, objetos e

\footnotetext{
${ }^{21}$ ROSSET, Clément. A Antinatureza: elementos para uma filosofia trágica. Rio de Janeiro: Espaço e Tempo, 1989. p. 23.

22 "Toda a sociedade, toda a cultura cria, inventa, institui uma determinada idéia do que seja a natureza. Nesse sentido, o conceito de natureza não é natural, sendo na verdade criado e instituído pelos homens. Constitui um dos pilares através do qual os homens erguem as suas relações sociais, sua produção material e espiritual, enfim, a sua cultura". GONÇALVES, Carlos W. P. Os (Des)caminhos do Meio Ambiente. São Paulo: Contexto, 1996. p. 23.

${ }^{23}$ MOSCOVICI, Serge. Sociedade contra a natureza. Rio de Janeiro: Editora Vozes, 1975. p. 15.

${ }^{24}$ HORKHEIMER, Max e ADORNO, Theodor. O Conceito de Iluminismo. In: Textos Escolhidos. São Paulo: Nova Cultural, 1999. p. 25.
} 
métodos the oferecem "[...] $O$ mundo do cientista é tanto qualitativamente transformado como quantitativamente enriquecido pelas novidades fundamentais de fatos ou teorias." ${ }^{25}$ Não apenas o mundo do cientista, mas de certa maneira o mundo como um todo é transformado por estas novidades, seja do lado natural ou das sociedades; isto, evidentemente, se partimos do ponto de vista da ciência como uma das matrizes formadoras destes dois elementos. As "matter of facts", os fatos científicos oriundos do conhecimento objetivo sobre a natureza contribuiriam no sentido de cristalizar socialmente os enunciados científicos enquanto algo inquestionável, ou pelo menos irrefutável em sua essência. O nó górdio que se forma nos estudos científicos, e que enredariam as várias tonalidades do real sobre a ótica das ciências, misturaria as essências e daria as cores estruturais das ciências e dos cientistas. Para Bruno Latour, se aquilo que aparecia em separado no projeto moderno - natureza e sociedade - e definia as fronteiras entre os campos do saber, ou entre o que é ciência e a não-ciência, num olhar mais dedicado e focado nas abrangências que caracterizariam as atividades cientificas, poderia se perceber que as nuances entre os mundos em separados estão mais próximas, misturadas até, do que se poderia conceber.

[...] Um mesmo fio conecta a mais esotérica das ciências e a mais baixa política, o céu mais longínquo e uma certa usina no subúrbio de Lyon, o perigo mais global e as próximas eleições ou próximo conselho administrativo. As proporções, as questões, as durações, os atores não são comparáveis e, no entanto, estão todos envolvidos na mesma história. ${ }^{26}$

Não seria possível desvincular da mesma história os elementos que envolvem a prática das ciências, não havendo somente o objeto e o sujeito do conhecimento de um lado e o sujeito e seus companheiros, sociedade, política de outro, mas sim a relação intrínseca de todos os fatores na formação de uma ciência, uma pesquisa, um

\footnotetext{
${ }^{25}$ KUHN, Thomas. Op. cit. p. 26.

${ }^{26}$ LATOUR, Bruno. Jamais fomos modernos: ensaio de antropologia simétrica. Rio de Janeiro: Ed. 34, 1994. p. 7.
} 
pesquisador, um cientista. Esta argumentação é a base para aquilo que se segue, o entendimento de uma ciência que se concretiza tanto na adequação da natureza quanto nas suas relações com a sociedade, economia ou política, para a formulação dos enunciados.

Em vista desses três pontos da abordagem metodológica, a dissertação foi dividida em três capítulos. Os temas que dão o mote de cada capítulo têm por função apresentar um quadro sobre a situação da pesquisa em energias alternativas no Estado de São Paulo durante a década de 1990, além da análise do Programa Interunidades de Pós-Graduação em Energia da USP, enquanto estudo de caso sobre a temática.

O primeiro capítulo tem como proposta trazer à tona a historicidade do conceito de energia, marcando os eventos-chave para que seja possível o entendimento da produção científica do PIPGE na década de 1990 e início dos anos 2000. Inicialmente será traçada a presença deste conceito nas sociedades ocidentais, principalmente na Europa do século XIX e no Brasil do XX, procurando ressaltar os processos históricos nos quais se deu a valorização da energia como produto cuja necessidade se tornará fundamental para as nações modernas. Em seguida, apresento a matriz energética mundial e a brasileira, com seus processos de formação e trato da reestruturação energética brasileira e suas conseqüências na década de 1990. O capítulo traz também as principais conferências internacionais sobre meio ambiente e desenvolvimento, que tiveram como uma de suas preocupações a temática - energias alternativas - assim como a influência que estas reuniões de cúpula tiveram na América Latina, Brasil e Estado de São Paulo.

O segundo capítulo apresenta a descrição do Programa Interunidades de PósGraduação em Energia: sua origem, disciplinas ministradas, produção, direcionamentos etc. Analiso, em seguida, a produção científica textual do PIPGE. Os artigos em 
periódicos nacionais e internacionais, as teses e dissertações e os textos para eventos serão as fontes documentais para se compreender o discurso do qual o Programa se valia para a sua argumentação. Neste item também ressalto quatro características que marcam a literatura produzida pelos pesquisadores: a questão dos autores, os leitores que são os alvos dos pesquisadores, os direcionamentos de cada tecnologia das fontes estudadas e os discursos específicos sobre as tecnologias.

Por fim, no terceiro capítulo analiso o conjunto de idéias que fundamentam as pesquisas em energias alternativas no período recortado, 1992 a 2002, com a hipótese de que haveria nos meios científicos envolvidos com o tema energia a noção alegórica de uma "cornucópia energética" proveniente da natureza, que estaria materializada nas fontes renováveis, ou seja, de caráter inesgotável e de acesso a todos. Na argumentação, foram trazidas questões que permeiam os estudos sobre o tema e que sugerem tal hipótese. Em primeiro, trato da questão do Próalcool como uma idéia que fortaleceria as pesquisas em biomassa de cana-de-açúcar e também o progresso tecnológico como uma noção inserida nos trabalhos sobre energia solar do PIPGE. Em seguida analiso o surgimento do conceito de "desenvolvimento sustentável" ou "sustentabilidade" baseado no qual as nações deveriam procurar soluções ambientais limpas para dar continuidade ao processo de desenvolvimento econômico. Neste quesito, as fontes alternativas dariam a resposta para a produção de energia em curto prazo e também viabilizariam uma opção ao futuro energético da humanidade. Os pesquisadores do Programa utilizam tal conceito em seus trabalhos, inserindo-os no contexto de preocupações com o futuro da humanidade e, portanto, servindo muitas vezes de justificativa para as pesquisas que estavam empreendendo.

Com esta divisão, pretendo apresentar a produção científica sobre energias alternativas do PIPGE/USP enquanto inserida numa perspectiva ampla de análise. 
Conjugando as questões científicas, políticas, ambientais e sociais que compõem este assunto, procurei incluir este trabalho nos debates e auxiliar nas reflexões a respeito das escolhas científicas e políticas sobre o tema energia. Algumas lacunas foram deixadas, tanto pelo fato de extrapolarem negativamente os objetivos ou de não poderem ser respondidas pelas fontes. Estas brechas são sugestões que faço para pesquisas que vierem e que, com outro olhar sobre as fontes, possam fechar as lacunas abertas. 
"Há um agente poderoso, obediente, veloz, de fácil manejo que se amolda a todos os usos e que reina como senhor absoluto a bordo do Naútilo. Elle, aqui tudo faz. Ilumina, aquece, é vida e alma de meus aparelhos mecânicos. Este agente animado é a eletricidade." (Júlio Verne, 1869) 


\section{Capítulo 1 - O conceito de energia: ciências e sociedade}

O levantamento das bibliografias sobre energia e também das fontes referentes ao Programa Interunidades de Pós-Graduação em Energia da USP (PIPGE/USP) me levou a determinar eventos-chave para a compreensão de sua produção cientifica na temática: energias alternativas. Em vista disto, este capítulo trata desses acontecimentos e está orientado por estas questões: o que é energia nos moldes modernos do conceito? Qual a compreensão de energia dentro da ótica social? Como ocorreu a formação da matriz energética brasileira nos anos 1970? Como se formou um contexto favorável às energias alternativas na década de 1990? Questões que servem de direcionamento para compreender os processos de constituição de um programa científico e sua necessidade em meio às sociedades e que abrirão caminho para o entendimento do discurso científico presente na produção do PIPGE ao longo dos anos 1990 até o ano de 2002.

Para responder tais questões, o capítulo divide-se em duas partes, a primeira refere-se à historicidade do conceito de energia, trazendo os encaminhamentos políticos e econômicos que envolvem o termo, tal como a formação da matriz energética mundial e a brasileira, principalmente no século XIX e XX. Analiso também a reestruturação energética ocorrida no Brasil e suas conseqüências na década de 1990.

Num segundo momento, o mote é a questão científica e política envolvida, trazendo as reuniões mundiais e as comissões regionais e locais que desenvolveram trabalhos a respeito do tema energia. Desta maneira, procuro demonstrar os múltiplos aspectos que envolvem o conceito de energia, ressaltando sua utilização social e o processo mercadológico que passou ao longo do período abordado.

\section{Energias: Cotidiano e Trabalho}


A energia elétrica animava os habitantes do município de São Paulo no início do século XX. Tal fato se devia à recente construção de hidrelétricas no Rio Parnaíba em 1901 e depois de alguns anos no Rio Guarapiranga, quando a cidade se colocava entre aquelas no Brasil que cada vez mais necessitavam da energia em seu cotidiano, como afirma Janes Jorge em tese sobre o Rio Tiete, que cruza a urbe:

Na São Paulo cuja população não parava de aumentar e que adotava padrões de produção e consumo cada vez mais parecidos com aqueles desenvolvidos nas grandes cidades norte-americanas e européias, a demanda por eletricidade era crescente. A industrialização paulatinamente se consolidava e, embora os motores a vapor fossem importante força motriz das fábricas, os motores elétricos eram cada vez mais requisitados. [...]. ${ }^{27}$

Tal acontecimento levou a que as represas das usinas se transformassem em local de lazer e de orgulho dos habitantes de São Paulo, símbolo da modernidade almejada nas grandes obras energéticas. Extrapolando a condição econômica de um espaço de produção de energia, as represas foram tratadas enquanto símbolos de modernidade, de avanço tecnológico, levando também, de forma progressiva, à dependência da eletricidade esses moradores, as indústrias, o cotidiano da urbe.

Toda modernidade tem seus custos, quando anos depois, em 1924 e 1926, São Paulo, com seu crescimento demográfico acelerado, se encontrava em meio a uma crise energética causada pela estiagem e o baixo índice de água nos reservatórios das usinas hidrelétricas. Segundo Janes Jorge, os bondes elétricos não conseguiam subir as ladeiras, anúncios luminosos foram proibidos nas lojas, moradores temeram ficar no escuro e os industriais de irem à falência devido às máquinas paradas; isso era o resultado direto da "[...] demanda crescente de eletricidade, fato em São Paulo, e a

\footnotetext{
${ }^{27}$ JORGE, Janes. Tietê, o rio que a cidade perdeu: o Tietê em São Paulo (1890-1940). São Paulo: Alameda, 2006. p. 76.
} 
ausência de investimentos que aumentassem a produção faziam da crise algo previsível, embora fosse antecipada pela estiagem. [...].", 28

A energia como mercadoria ganha seus proprietários. Na São Paulo de até metade do século XX, a Light, como ficou conhecida a empresa elétrica, monopolizava a geração e distribuição da energia. Definia os planos de eletrificação, inclusive os modos de aproveitamento dos recursos hídricos, como Tiete e o Pinheiros, devido a formarem o abastecimento de água para as represas da empresa elétrica.

A eletrificação da cidade de São Paulo é um exemplo das mudanças sociais e econômicas que a energia ocasionou. Estilos de vida, formas de produção, transportes e lazer foram profundamente alterados pelo uso das fontes modernas de energia, a eletricidade e o petróleo, especialmente. Mesmo os racionamentos, a escassez de eletricidade, tal como ocorriam em São Paulo, não eram motivos de desânimo da população frente às possibilidades imensas que a eletricidade proporcionava. Eles eram traços comuns de uma tecnologia que ainda não estava adaptada ao cotidiano das grandes cidades, mas que estava em processo de ser incluída e até mesmo de se tornar fundamental nas atividades da maioria dos seres humanos ao redor do mundo.

Os processos sociais, psicológicos e econômicos ocorridos na cidade de São Paulo do início do século XX podem ser entendidos como inseridos num contexto maior de modificação do sentido do conceito de energia das sociedades modernas. Tais transformações não foram apenas resultantes de uma sociedade especifica, mas estavam sistematicamente ocorrendo em todo o mundo, especialmente na Europa deste período. Dessa maneira, se faz necessário aqui abordar este processo, caracterizando suas principais ocorrências e mudanças nos séculos XIX e XX, período da consolidação do capitalismo em algumas nações européias e da América do Norte.

\footnotetext{
${ }^{28}$ JORGE, Janes. Op. cit. p. 79.
} 
No século XX o ser humano pode ser considerado um consumidor compulsivo de fontes energéticas, seja na sua alimentação diária, em suas atividades do dia-a-dia ou em seu lazer aos finais de semana. Dessa forma, podemos caracterizar as sociedades como organismos "energivoros", ou seja, que se alimentam e dependem constantemente da energia nos processos de subsistência. Calorias, Joules, Watts, Volts, são unidades de medida da energia, com que convivemos diariamente em nossos afazeres domésticos, em nosso trabalho, no lazer, na leitura. No cotidiano, as atividades simples, como dormir ou ler um jornal, até as complexas, como o funcionamento de um computador ou de automóveis, geram e gastam energia.

O termo energia, de maneira geral, é um conceito cujo enunciado é proveniente da Física: “capacidade de realizar trabalho”, elaborado no século XIX por dois cientistas: Clausius e Kelvin. No entanto, o significado e a aplicação por outras ciências do conceito o tornam aberto a variações na interpretação de seu enunciado, geralmente adaptando-o às normas e leis que regem a área. Na Ecologia e nas Ciências Humanas, de forma mais acintosa, a "energia" ganha novos matizes, ora assemelhando-se e ora se afastando da explicação original do termo. Ecologicamente, todo ser vivo é uma fonte potencial de energia e historicamente as sociedades humanas fazem uso dos mais variados tipos de fonte energética para a manutenção da sua própria existência, principalmente pela utilização do fogo.

A capacidade de gerar trabalho e as trocas entre fontes conceituam e mostram os possíveis usos da energia em termos físicos e ecológicos. Nas ciências humanas, fundamentalmente, o conceito ainda é a capacidade de gerar trabalho, por meio da força física dos seres humanos na caça, pesca, agricultura, na linha de produção das fábricas ou mediante o uso de fontes energéticas diversas servindo de ferramentas na atividade humana, tal como a lenha e o carvão, gerando calor, para preparar alimentos ou mover 
máquinas, os combustíveis para movimentar veículos e a eletricidade para a iluminação e equipamentos eletrônicos. Esta relação entre humanidade e energia inicia-se antes mesmo da capacidade de obtenção do fogo; a simples necessidade de alimentar-se já é uma busca por energia para movimentar o corpo, para subsistir. No entanto, nos últimos duzentos anos, houve uma modificação significativa nesta relação entre energia e ser humano.

Com o advento da Revolução Industrial no Ocidente a partir do século XVIII, o uso da energia deixou de ser apenas uma ferramenta para o ser humano e aos poucos se converteu em uma das necessidades básicas à manutenção do modo de vida das sociedades modernas. Ocorreu um aumento na dependência de fontes energéticas que proporcionassem o funcionamento de máquinas e utensílios do cotidiano da maioria das pessoas em todo o planeta. $\mathrm{O}$ engenho humano que permitiu a obtenção de energia em larga escala, mediante a construção de unidades geradoras como as hidrelétricas, as termoelétricas, usinas nucleares, refinarias de petróleo, minas de carvão, acabou por “aprisionar" a si próprio na crescente necessidade de energia para a sua sobrevivência.

Não é apenas a soma de outro elemento na conceituação do termo energia, pois também energia irá significar socialmente a manutenção da atividade humana. Agora ao escrever esta dissertação, faço uso mais que necessário do computador, ao mesmo tempo em que mantenho a lâmpada acesa e um aparelho de som tocando ao fundo, como também o fax, o telefone, a geladeira, e demais equipamentos ligados intermitentemente à rede elétrica. Neste sentido, Enzo Tiezzi, na década de 1980, expõe que "Tudo é energia" e que "cada um de nós tem um conhecimento intuitivo do significado da expressão 'energia'”, incrementando o conceito ao indicar que a “[...] energia é também a informação que introduzimos ou o enriquecimento de informações 
que obtemos num processo produtivo." ${ }^{29}$, extrapolando o significado da Física e da Ecologia, dando novos sentidos ao termo, até mesmo o tornando plural, ou seja, por que não energias.

O período entre os séculos XIX e XX pode ser caracterizado por uma constante expansão no parque gerador de energia entre as sociedades ocidentais, pela constante busca de novos depósitos de petróleo, gás natural, carvão, pelo crescimento das plantações de bicombustíveis e por novas unidades nucleares. Vivemos num planeta onde a luz de vela é um sinônimo de um encontro romântico. Neste contexto, a energia passou a representar mais do que a capacidade de gerar trabalho, mas o próprio trabalho nas sociedades modernas depende da produção de energia para manter seu funcionamento cotidiano. A produção de trabalho deixa de ser um processo natural de trocas energéticas para se tornar um procedimento mecânico e por sua vez fundamental. Adam Smith, no século XVIII, definia trabalho, segundo explica Foucault, enquanto uma medida constante na trocas de objetos, portanto, "[...] toda mercadoria representava certo trabalho, e todo trabalho podia representar certa quantidade de mercadoria [...]." ${ }^{30}$ Gerar trabalho ou esforço na realização de algum tipo de atividade se torna mais um detalhe na matriz econômica que se desenvolvia no período de Smith, representando algo além do enunciado físico de energia, uma mercadoria, uma representação simbólica da trocas produtivas na sociedade européia.

Do uso da energia proveniente dos músculos humanos ou animais ao vapor e à eletricidade, até a chegada dos reatores nucleares, o mundo ocidental necessitou de menos de um século em pesquisas científicas, fato que não representa um progresso ou melhoria nas fontes energéticas e nas formas como são aproveitadas, mas sim, a

\footnotetext{
${ }^{29}$ TIEZZI, Enzo. Tempos históricos, tempos biológicos. A Terra ou a morte: os problemas da nova ecologia. São Paulo: Nobel, 1988. p. 83.

${ }^{30}$ FOUCAULT, Michel. As palavras e as coisas. São Paulo: Martins Fontes, 2007. p. 348.
} 
diversificação da matriz energética, inclusive com o incremento na eficiência do aproveitamento de cada uma dessas fontes. O destaque fica para o petróleo, principal energia primária consumida ao redor do mundo no século XX, usada em larga escala em processos industriais, nos transportes, com seus derivados empregados como matériasprimas de produtos de uso cotidiano, como o plástico e a borracha, além de proporcionar a geração de eletricidade, forma secundária de energia utilizada nos meios urbanos e mais recentemente nas zonas rurais.

Estas alterações e diversificações na utilização das fontes energéticas constituíram e acompanharam todo um processo, embora com início lento, de transformações sociais. Da pequena produção artesanal, as manufaturas, até as indústrias e a constante urbanização das populações do Ocidente, surgiram novas relações entre seres humanos, que deram começo a um momento inédito no sistema econômico, caracterizando o que Hobsbawm chamou de "A era do Capital”. Este período de intensas modificações nas estruturas das sociedades, inicialmente as européias e posteriormente atingindo o Novo Mundo e parte da Ásia, chegando ao Japão, definiu-se pela intensidade da exploração dos recursos naturais, carvão e lenha de forma mais acintosa, e pelo aumento na velocidade dos transportes e na ligação eficiente dos espaços envolvidos com os meios produtivos, ou seja, a indústria, os portos, as áreas comerciais e as matérias primas. ${ }^{31}$

Eric Hobsbawm, em "A era do Capital”, sua obra sobre o estabelecimento do capitalismo no século XIX nas sociedades ocidentais, revela uma das causas desta dependência energética. Uma Europa que necessitava interligar suas nações, promovendo o transporte de matérias-primas e bens industrializados, precisava de um modo rápido e barato de gerar essa ligação; adotava então, as locomotivas como meio

\footnotetext{
${ }^{31}$ HOBSBAWM, ERIC J. A era do capital. Rio de Janeiro: Paz e Terra, 1996.
} 
de conduzir tanto passageiros quanto mercadorias, para seus portos, fábricas e mercados. As ferrovias se espalhavam pelo território europeu e fenômeno semelhante na América décadas depois, nos EUA possibilitando a ligação entre seus estados e oceanos. $^{32}$

O transporte ferroviário se transformava no meio principal de locomoção no mundo ocidental, proporcionando a aproximação entre culturas distintas e conseqüentemente o intercâmbio entre elas. As locomotivas, em curtas ou longas distâncias, utilizavam combustível para mover seus vagões. O vapor obtido através da água fervente, aquecida nas caldeiras da locomotiva, era gerado pela queima do carvão mineral e, em alguns casos, a lenha. Com isso se aumenta a extração de carvão nas minas e a derrubada de árvores. Para Hobsbawm:

[...] Os meados do século XIX foram fundamentalmente a era da fumaça e do vapor. A produção de carvão já de longa data era medida em milhões de toneladas, mas agora chegava a ser medida em dezena de milhões para países individuais e em centenas de milhões para o mundo [...] a produção mundial de carvão multiplicou-se por duas vezes e meia, a produção de ferro multiplicou-se por quatro vezes. A força total de vapor, porém, multiplicou-se por quatro vezes e mais, subindo de uma estimativa de 4 milhões de HP em 1850 para cerca de 18,5 milhões de HP em $1870 .^{33}$

O incremento da velocidade de locomoção e a relação entre diferentes sociedades produziam um caminho sem retorno; homens e máquinas transformaram-se em sinônimos, cuja síntese era a energia. As cidades européias, aos poucos, iam ganhando uma nova característica; as populações, até então predominantemente locadas no meio rural, passavam a migrar para centros urbanos, local das indústrias e do emprego assalariado. Paralela a esta revolução demográfica tínhamos uma revolução científica, com a criação de novos elementos químicos, o uso da eletricidade e inovações tecnológicas que abriam as portas para uma nova revolução industrial, esta

\footnotetext{
${ }^{32}$ Idem.

${ }^{33}$ HOBSBAWM, ERIC J. Op. Cit. pp. 67-68.
} 
mais generalizada, atingindo diversos países do continente europeu e também fora dele, nos Estados Unidos e Japão. ${ }^{34}$

Todas estas revoluções contaram com a participação da energia. As migrações para as cidades geravam o consumo de alimentos, carvão e lenha, além da eletricidade, ao final do século XIX, quando os meios urbanos passaram a ser atendidos por redes, postes e fios de distribuição elétrica. No âmbito científico, as fontes energéticas permitiram a invenção de novas tecnologias e equipamentos, de certa forma, constituindo os laboratórios e modernos métodos de pesquisa. $\mathrm{O}$ maquinário das indústrias começava a operar com maior capacidade e eficiência no uso energético, aumentando a lucratividade e a manipulação do operário assalariado, sujeito ao ritmo das máquinas e ao novo tempo das cidades. A eletricidade proporcionou a vida noturna, com a iluminação pública trazendo o "sol" para as noites dos cidadãos cosmopolitas. Em imagens de satélite recentes, tiradas durante o período noturno, podemos divisar facilmente as grandes aglomerações urbanas ao redor do planeta por causa da iluminação artificial que emana desses centros populacionais.

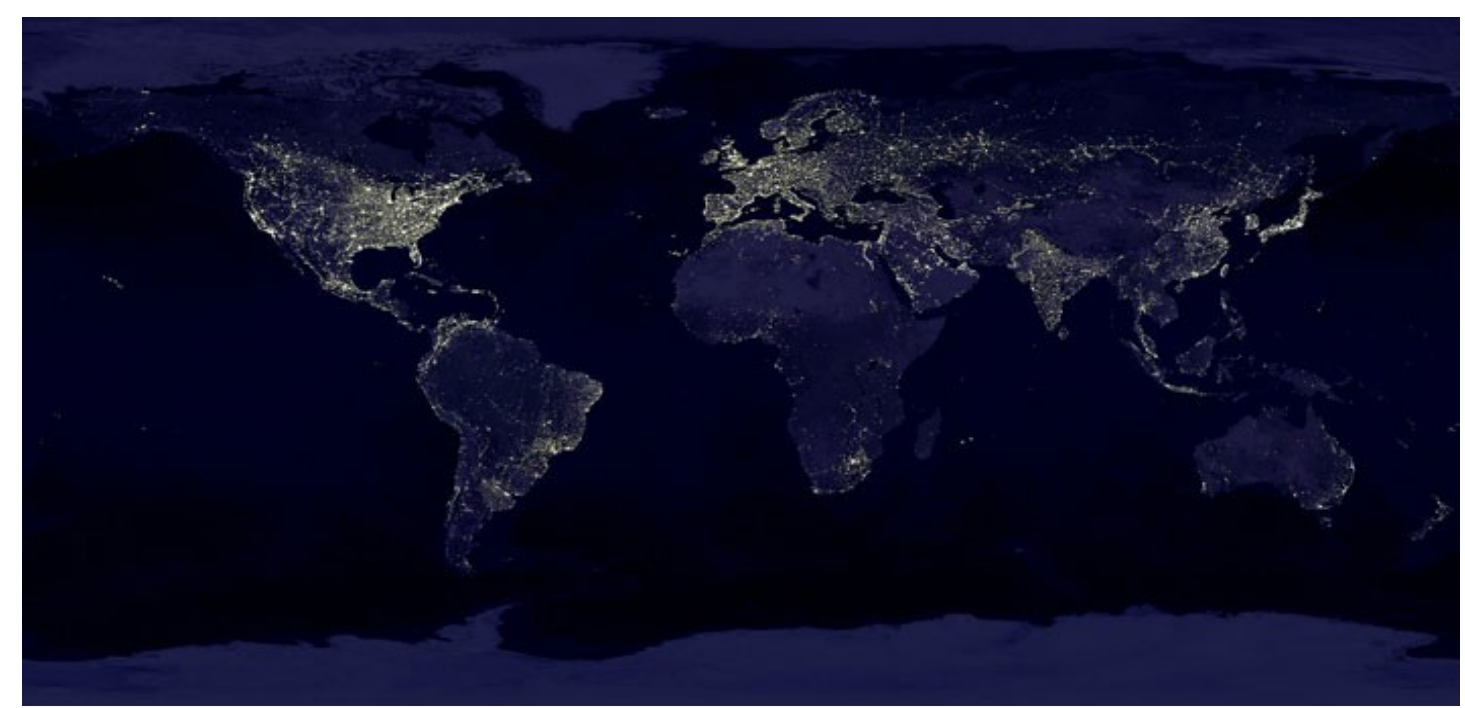

Figura 1 - Imagens do planeta tiradas pelo do Defense Meteorological Satellite da NASA. Na noite de 23/10/2000. http://visibleearth.nasa.gov/view rec.php?id=1438

\footnotetext{
${ }^{34}$ Ibid.
} 
Ao olharmos esta imagem, uma montagem de diversas fotos noturnas do planeta tiradas por um satélite da agência espacial dos EUA no ano de 2000, fica fácil divisar os grandes centros urbanos, assim como as regiões industrialmente desenvolvidas. Energia no século XX se tornou sinônimo de riqueza. Populações carentes, países economicamente dependentes são encontrados na imagem pelas lacunas de pontos luminosos, tal como grande parte da África, Ásia central, Centro da América Latina. A partir do século XIX, a energia como algo "gratuito”, disponível a todos na natureza, passa a ser um objeto, um bem material, cuja propriedade está nas mãos de indivíduos ou de governos nacionais. O ser humano não iria mais sair em busca da lenha para cozinhar ou se aquecer; nas cidades modernas será a energia que virá ao encontro deste, evidentemente a um preço determinado.

O conceito de energia se materializa, ganha uma imagem ou imagens para as pessoas. Este pode ser o líquido que move os automóveis, as grandes barragens, as plantações de cana-de-açúcar, a lâmpada e a tomada. A própria energia gerada pelo suor do corpo humano se transforma em produto e propriedade, vendida ou alugada por um salário nas fábricas, escritórios, no comércio, nas escolas e etc. No sistema capitalista, a energia, nas palavras de Fernando Henrique Cardoso, ao analisar a matriz energética brasileira na década de 1970, pode ser considerada a "espinha dorsal" de todo o sistema econômico contemporâneo. ${ }^{35}$

\section{Formação da Matriz Energética Mundial e a Brasileira}

Esta multiplicidade na caracterização da energia no mundo contemporâneo teve no carvão seu principal personagem durante o século XIX e início do século XX. O

\footnotetext{
${ }^{35}$ CARDOSO, Fernando Henrique. Perspectivas de desenvolvimento e meio ambiente: o caso do Brasil. In: Encontros com a Civilização Brasileira. V. 20, 1979. pp. 31-70.
} 
carvão neste período foi chamado por Henry Peyret, em seu livro sobre a formação da matriz energética mundial, como o "rei dos combustíveis". Serve como fonte energética para os maquinários da primeira Revolução Industrial, esta restrita somente à Inglaterra, na qual a produção de carvão era, em 1800, de 15 milhões de toneladas, sendo a maior produtora mundial. ${ }^{36}$ Esta significativa extração de carvão se deveu à utilização de máquinas que facilitariam a obtenção do produto em quantidades significativas para a indústria:

A máquina a vapor [...] permite desembaraçar a mina da água que ali se acumula e possibilita assim a extração do carvão em quantidades industriais. Diante disso, o carvão se torna matéria-prima abundante, oferecendo à máquina a vapor perspectivas práticamente ilimitadas. É um investimento depressa compensado. ${ }^{37}$

Nesta relação, a máquina que utilizava carvão em seu funcionamento, por sua vez, ajudou melhorar a eficiência na extração do próprio carvão para a manutenção do sistema fabril, um ciclo fechado, tal como nas cadeias alimentares dos ecossistemas, nos quais ocorre a alimentação por fenômenos internos a sua atividade. No entanto, a supremacia do carvão como fonte principal de energia começa a perder espaço na virada do século XIX para o século XX, pelo aproveitamento do petróleo em processos químicos, iluminação pública e no desenvolvimento de motores a combustão utilizando os derivados do petróleo como combustível. Conforme aponta Peyret, se inicialmente não havia uma "disputa” entre ambos pelo controle do mercado energético, já que o carvão se mostrava um combustível superior, seja pela disponibilidade ou então pela eficiência na utilização em maquinários, este quadro mudou quando um novo processo para aquecimento, utilizando mazute ${ }^{38}$, entra na concorrência:

\footnotetext{
${ }^{36}$ PEYRET, Henry. A batalha pela energia. São Paulo: Difusão Européia do Livro. 1961.

${ }^{37}$ PEYRET, Henry. Op. cit. p. 19.

${ }^{38}$ Ou simplesmente diesel: "Mazute: Antiga designação comercial dos óleos pesados do petróleo, usado nos motores do tipo DIESEL. (É um combustível líquido, viscoso e preto, obtido como resíduo da destilação do petróleo, e mais comumente chamado óleo diesel)". Cf. Dicionário Enciclopédico Koogan, Larousse, Seleções. Rio de Janeiro: Editora Larousse do Brasil Ltda, 1982. Vol. 1. p. 547.
} 
[...] A iniciativa dirige-se primeiramente para a fornalha dos navios. As primeiras experiências tentadas por volta de 1900 logo evidenciaram-se como conclusivas. O mazute simplifica a manutenção tanto durante o carregamento como em período de marcha, e graças à sua alimentação automática suprime os foguistas, êsses "forçados do mar". A saída é acelerada; o rendimento é melhor; o poder calorífico é de $50 \%$ superior ao do carvão; economiza mão-de-obra e aparelhamento, reduz gastos de exploração, assegura maior aproveitamento do espaço [...]. ${ }^{39}$

O petróleo, com um novo refino e aplicado sobre uma tecnologia diferente da usual, apresenta melhores rendimentos e eficiência que o carvão em seu uso como energético. Aos poucos o petróleo deixa a indústria naval e se encaminha para a aplicação em residências, no aquecimento e depois, com a criação de motores Diesel, vai para as fábricas e os transportes terrestres. ${ }^{40}$

Durante as primeiras décadas do século XX e até aproximadamente 1960, o carvão ainda se manteve como principal fonte de energia consumida ao redor do mundo, com $60 \%$ frente às demais fontes; porém, mesmo sendo significativa a porcentagem, esta se mostrava em declínio acentuado, pois o consumo chegou a ser de 95\% em 1913; portanto, nitidamente o combustível foi perdendo espaço para seu substituto imediato, o petróleo. ${ }^{41}$

O uso mais acentuado do petróleo acontece ao final da II Guerra Mundial. O combustível soma-se aos esforços de guerra, de ambos os lados na disputa, o que necessariamente previa o aumento na sua extração, refino e transporte. Montou-se uma estrutura petrolífera que, a partir de 1945 até a década de 1970, proporcionava a utilização do óleo a preços baixos, US\$2 o barril, proveniente principalmente de países no Oriente Médio, para o consumo nos EUA, Europa e países em processo de industrialização, como o Brasil.

\footnotetext{
${ }^{39}$ PEYRET, Henry. Op. cit. p. 25.

${ }^{40}$ PEYRET, Henry. Op. cit.

${ }^{41}$ PEYRET, Henry. Op. cit.
} 
As matérias-primas energéticas, neste padrão de vida pautado pelo industrialismo e mercado de capitais, justificam-se como a "espinha dorsal" de todo sistema, um elemento crucial para a manutenção do estilo de desenvolvimento econômico iniciado com a Revolução Industrial e o Capitalismo do século XVIII e XIX. Gerald Manners, ao tratar da geografia da energia no ano de 1964, compreende a questão da seguinte forma:

A energia, portanto, constitui fator criticamente importante sob três aspectos da vida econômica. Sua utilização acha-se intimamente relacionada com a natureza e a rapidez do desenvolvimento econômico, com as variações espaciais do padrão de vida, e com alguns elementos-chave na interação espacial. É ainda mais importante até o ponto em que o crescimento econômico, e a rápida substituição de energia animada por formas inanimadas, levaram à expansão da produção e consumo de energia numa taxa sempre crescente nas últimas décadas [...]. ${ }^{42}$

O petróleo e sua indústria passam a predominar na geração de energia primária e deter o controle do mercado energético no mundo pós-Segunda Guerra. No campo da energia secundária, será a eletricidade a principal forma de energia gerada. Instalações termoelétricas, hidrelétricas e usinas nucleares serão construídas em diversos países, cada uma em seu tempo. Enquanto o petróleo teve sua relação com os transportes e as indústrias, a eletricidade ganha contornos no cotidiano, motivado pelo surgimento de eletrônicos tais como os eletrodomésticos; a televisão; a geladeira; o aspirador de pó etc. A eletricidade se populariza e se transforma em serviço básico junto à saúde, transporte, empregos.

No Brasil, com seu processo de industrialização tardia e ainda não considerada completa nos dias de hoje, o uso moderno de fontes energéticas teve início acelerado, visando à criação de um parque energético para dar suporte às desejadas indústrias. $\mathrm{O}$ país se baseou no petróleo como combustível principal, seguindo a tendência mundial

\footnotetext{
${ }^{42}$ MANNERS, Gerald. Geografia da Energia. São Paulo: Zahar Editores, 1976. p. 14
} 
nas décadas de 1950 e 1960, contando com os preços baixos do produto, que perduraram até 1973, importando a maior parte do consumo nacional e com uma produção interna do óleo em pequenas quantidades. Neste sentido, foram feitas as primeiras tentativas de exploração do petróleo em território nacional no ano de 1954 junto à criação de uma companhia estatal que administraria a extração, o refino e a distribuição do produto, a Petrobrás. ${ }^{43}$

Quanto ao setor elétrico, no qual o país apresentava o maior déficit, a capacidade instalada salta de 1.009 MW em 1940 para 5.729 MW em 1962, ano da criação da estatal responsável pela energia elétrica no país, a Eletrobrás. A companhia estatal promove obras de expansão do parque gerador, atingindo em 1978 o total de 21.200 MW ${ }^{44}$, sem contar os acréscimos provenientes dos complexos hidrelétricos em fase final de construção, Itaipu e Tucuruí. ${ }^{45}$

As usinas mostram que os investimentos brasileiros na geração elétrica focaram no potencial nacional para a fonte hidráulica. Com a inversão demográfica nos anos 1960 e 1970, o país necessitava expandir sua matriz geradora na iniciativa de atender a demanda crescente da nova população urbana, concentrada especialmente nas regiões sudeste e sul, nas quais a industrialização era um fenômeno mais acentuado.

A utilização de hidrelétricas na matriz nacional se consolida na década de 1970. Nesse decênio foram finalizadas e construídas plantas hidráulicas em diversos pontos do território nacional, privilegiando-se as regiões Sudoeste e Sul do país. A década culmina com a construção do Complexo Hidrelétrico Itaipu Binacional, que no período

\footnotetext{
${ }^{43}$ Cf. PEIXOTO, João B. O desafio da crise energética. Rio de Janeiro: CAPEMI, 1981; A ENERGIA ELÉTRICA NO BRASIL: DA PRIMEIRA LAMPPADA À ELETROBRÁS. Rio de Janeiro: Biblioteca do Exército, 1977.

${ }^{44}$ CALABI, André Sandro et. al. A energia e a economia brasileira: interações econômicas $e$ institucionais no desenvolvimento do setor energético no Brasil. São Paulo: Pioneira: Fundação Instituto de Pesquisas Econômicas, 1983.

${ }^{45}$ A Usina de Itaipu no Rio Paraná iria produzir 12.600 mil KW, em 18 unidades geradoras e a Usina de Tucuruí no Rio Tocantins produziria $1.640 \mathrm{mil} \mathrm{KW.} \mathrm{(Cf.} \mathrm{PEIXOTO,} \mathrm{João} \mathrm{B.} \mathrm{O} \mathrm{desafio} \mathrm{da} \mathrm{crise}$ energética. Rio de Janeiro: CAPEMI, 1981.)
} 
era a maior usina do tipo no mundo, sendo uma obra dividida entre o Paraguai e o Brasil.

Esse cenário que se esboçava no setor elétrico, com a finalização de obras e a construção de novas unidades hidrelétricas, representou o auge de um processo iniciado no ano de 1946, com a criação da CHESF (Companhia Hidrelétrica do São Francisco). Naquele momento, logo ao final da Segunda Guerra Mundial, o parque gerador de eletricidade era insuficiente para atender a crescente demanda originada tanto da urbanização acentuada como dos planos de industrialização, tendo em vista o desenvolvimento econômico do Brasil. ${ }^{46}$ Para João B. Peixoto, ao final dos anos 1970:

Cerca de $23 \%$ do potencial hidrelétrico do País está aproveitado ou em construção. Em relação ao potencial avaliado de cada região, o Norte tem aproveitados ou em construção 4,3\%; o Nordeste, 57,6\%; o Sudeste, $42,1 \%$; e o Sul, $30,5 \%{ }^{47}$

Portanto, o potencial hidrelétrico aumentou e aumentaria significativamente a geração elétrica no Brasil, chegando em 1977 ao total de 92\% no fornecimento de eletricidade. Com as usinas em pleno funcionamento e a construção em andamento de outras grandes obras hidrelétricas, o governo militar acreditava que havia atingido o potencial hidráulico economicamente viável para atender a demanda de energia das regiões industrializadas do país.

A construção de usinas hidrelétricas e a utilização do petróleo caracterizam as principais fontes energéticas utilizadas pelo Brasil nos anos que se seguiram à década de 1970. Houve também a inclusão da energia nuclear e do álcool da cana-de-açúcar, mas essas tiveram uma participação relativamente pequena dentro da matriz nacional se comparada com as duas principais. Ainda, tais oscilaram entre períodos de crescimento, principalmente na década de 1980 e de declínio durante os anos 1990, sendo

\footnotetext{
${ }^{46}$ PEIXOTO João B. Op. cit.

${ }^{47}$ PEIXOTO João B. Op. cit. p. 98.
} 
questionadas em vários aspectos, desde problemas ambientais até sobre sua a viabilidade tecnológica. $^{48}$

Esse contexto continuou até os anos de 1990, quando começa uma nova fase no setor energético nacional, com os programas de privatizações iniciadas pelo Governo Collor de 1990 e levadas adiante com a primeira eleição de Fernando Henrique Cardoso em 1995. E também se soma a esse fato as suas conseqüências imediatas, com o blecaute na região sudeste e o programa federal de racionamento de energia, criando uma nova situação para a utilização de fontes energéticas, tanto pelo mercado privado quanto pela necessidade de geração emergencial para suprir a demanda da região sudeste do país.

O contexto da matriz energética nacional e o de São Paulo foram alterados profundamente com a consolidação das privatizações do setor energético no período que vai de 1990 a 1997 em todo o Brasil. No Estado de São Paulo a privatização do setor energético foi promulgada pelos atos de Quebra de Monopólio e Restrição ao Capital Estrangeiro e também pela Lei de Concessão de Serviços Públicos, todos ratificados naqueles anos. Concomitantemente a esses atos governamentais surgia também o Produtor Independente de Energia (PIE) enquanto uma legislação que abriria as redes de transmissão aos usineiros e seu excedente, definindo tarifas e protocolos de fornecimento.

A justificativa do Governo Federal para a venda das estatais se baseava na perspectiva na qual a privatização aliviaria a crise em que estava imerso o setor

\footnotetext{
${ }^{48}$ Sobre o álcool de cana-de-açúcar vide capítulo 3, quando farei uma análise aprofundada do tema em relação a sua presença na matriz energética nacional. Também, para uma compreensão da formação da matriz energética nacional na década de 1970, contemplando todas as fontes que constam desta, Cf. COLACIOS, Roger D. Matriz energética brasileira: consolidação, expansão, políticas e meio ambiente (1971-1979). In: Revista Territórios e Fronteiras V.2 N.1 - Jan/Jun 2009. pp 242-262.
} 
energético nacional, inaugurando um mercado competitivo, que beneficiaria diretamente os consumidores com o incentivo para o uso energético legado por cada empresa. ${ }^{49}$

O Governo do Estado de São Paulo atuou através da Secretária de Energia em relação ao programa de privatizações, de forma a colaborar com a transição do controle público ao privado. O Balanço Energético do Estado de São Paulo (BEESP) ${ }^{50}$ de 2000, com o ano base de 1999, ressalta a iniciativa do governo paulista do que chamou de "desverticalização" do sistema elétrico estadual, ficando a cargo da Secretaria a "[...] promoção de políticas públicas e planejamento do setor energético paulista." ${ }^{51}$ Dessa forma, a administração do parque gerador de energia elétrica estadual passou a ser gerida por concessionárias privadas e, conseqüentemente, como admite a própria Secretaria, tal modificação “[...] deverá provocar alterações no Balanço Energético do Estado de São Paulo." 52

Levando-se em conta que o Estado de São Paulo se caracterizou na década de 1990 por ser o maior consumidor energético nacional, com porcentagens variando de $28 \%$ a $32 \%$ do total consumido no país, além de importar grande parte da sua energia primária, entende-se que qualquer tipo de modificação na matriz elétrica paulista levaria a conseqüências em todo o parque energético nacional. Mas que tipo de alteração foi prevista? Estas previsões foram concretizadas? Quais foram os resultados da reestruturação do setor elétrico nacional?

\footnotetext{
${ }^{49} \mathrm{Cf}$. ABREU, Yolanda Vieira de \& SAUER, Ildo Luis. A reestruturação do setor elétrico brasileiro: questões e perspectivas. In: Anais do Congresso Brasileiro de Energia - CBE. Rio de Janeiro: Sociedade Brasileira de Planejamento Energético/COPPE-UFRJ/Clube de Engenharia, 1999. pp. 662-679.

${ }^{50}$ Este documento, atuando como vitrine da atuação do Estado de São Paulo no setor energético, traz em seu conteúdo os dados referentes à produção, consumo, demanda, planejamento e demais ações na área de energia no estado. Como o define a própria Secretaria: "Trata-se de um importante instrumento para a realização e a consolidação das políticas públicas no setor de infra-estrutura e constitui-se, também, em um elo fundamental para vários estudos, tais como: planejamento energético, introdução de novas tecnologias, busca de eficiência energética, preservação ambiental e desenvolvimento de novos negócios." (SÃO PAULO (Estado); Secretaria de Energia. Balanço energético do Estado de São Paulo 2000: Ano base: 1999. São Paulo: CESP, 2000.)

${ }^{51}$ SÃO PAULO (Estado); Secretaria de Energia. Balanço energético do Estado de São Paulo 2000: Ano base: 1999. São Paulo: CESP, 2000. (Apresentação)

${ }^{52}$ Idem. p. 5
} 
As privatizações de empresas estatais, que tiveram início em 1990 com o Plano Nacional de Desestatização, ainda no governo Collor, já incluíam neste processo o setor elétrico do país. $\mathrm{O}$ atrativo para os investidores vinha do fato que "[...] os interessados em participar dos leilões foram autorizados a usar títulos da divida externa para adquirir ações das empresas estatais [...]." Segundo escrevem Yolanda Vieira de Abreu e Ildo Luís Sauer, pesquisadores na área de planejamento energético do PIPGE, a intenção era de "[...] amortizar a divida externa com os bancos americanos $e$ europeus." ${ }^{53}$ Portanto, as privatizações propiciaram a abertura da economia do país ao capital estrangeiro, que adquiriu as empresas estatais a preços baixos, passando a controlar parte de serviços públicos no Brasil.

A etapa de privatizações, por conta desses fatores, ocasionou a reestruturação de todo o setor elétrico nacional. Tal alteração permitiu ao governo criar o Mercado Atacadista de Energia (MAE), pautado na liberdade de geração e de comercialização da energia, estimulando a competitividade no setor, levando-o a se inserir na lógica do "mercado livre". A abertura as empresas privadas acarretou a descaracterização do serviço de fornecimento energético como um bem público, universal, com acesso livre a todos os cidadãos do país. ${ }^{54}$ Neste sentido, a reestruturação do setor elétrico estabeleceu uma brecha no sistema de serviços públicos, com livre concorrência, levando à desigualdade entre consumidores, pois aquele que possui condições financeiras melhores irá se valer da rede elétrica, em detrimento dos desfavorecidos economicamente, que não poderiam pagar as tarifas e serviços privatizados. Portanto, uma mudança de foco dos serviços básicos, que deveriam ser oferecidos pelo Estado a

\footnotetext{
${ }^{53}$ SAUER, Ildo Luis, SANTOS, Rosana Rodrigues \& MERCEDES, Sônia Seger. A reestruturação do setor elétrico brasileiro e a universalização do acesso ao serviço de energia elétrica. In: Anais do Congresso Brasileiro de Energia - CBE. Rio de Janeiro: Sociedade Brasileira de Planejamento Energético/COPPE-UFRJ/Clube de Engenharia, 1999. p. 663

${ }^{54}$ Idem.
} 
sua população, a partir das privatizações seriam proporcionados mediante uma "restrição": a econômica.

O Estado investiu no parque elétrico nacional, trazendo fundos públicos para suprir a demanda necessária, e as usinas termoelétricas, após entrarem em funcionamento, iriam beneficiar com seu lucro as empresas privadas. Nesse sentido, no ano de 1999, o programa de privatizações poderia ser considerado um fracasso seis anos depois do início dos leilões de energia e quatro anos do começo das atividades das concessionárias privadas em São Paulo, como escreveram Yolanda Vieira de Abreu e Ildo Luís Sauer, ao concluírem que os benefícios que estavam na pauta da reestruturação e das privatizações não foram realizados, ou seja,

[...] diminuir o déficit público; diminuir as tarifa para os consumidores finais; administrar as empresas com maior eficiência, com a finalidade de beneficiar os consumidor [SIC]; promover o bem estar dos pobres e proteger o meio ambiente $\left[\ldots . .{ }^{55}\right.$

Nem mesmo a dívida externa brasileira foi amortizada; pelo contrário, passou de 110 bilhões de dólares antes das privatizações para mais de 250 bilhões, revelando que a iniciativa de diminuí-la não foi bem sucedida $^{56}$, sem contar o principal objetivo de reduzir a presença do Estado no fornecimento de energia elétrica; ao contrário " [...] $o$ resultado foi o fortalecimento do papel do Estado, não como protetor dos consumidores, mas das empresas e do capital." 57

Com o fortalecimento do Estado no setor energético nacional, por conta dos problemas gerados com as privatizações, permanecia a necessidade de políticas públicas e planejamento energético. Apesar de as privatizações terem sido iniciadas em 1993 e a venda das primeiras empresas de eletricidade a partir de 1995, somente dois anos

\footnotetext{
${ }^{55}$ ABREU, Yolanda Vieira de, \& SAUER, Ildo Luis. Op. cit. 1999. p. 678.

${ }^{56}$ CÂMARA DOS DEPUTADOS. Colapso energético no Brasil e alternativas futuras. Brasília: Câmara dos Deputados/Coordenação de Publicações, 2001.

${ }^{57}$ ABREU, Yolanda Vieira de, \& SAUER, Ildo Luis. Op. cit. 1999. p. 678.
} 
depois, no ano de 1997, foi que o Governo Federal criou a agência regulatória do setor elétrico nacional, visando ao controle do novo mercado energético nacional.

A Agência Nacional de Energia Elétrica (ANEEL) não representou para alguns especialistas em energia a devida ação regulatória do Estado, nem mesmo o devido marco regulatório das concessionárias privadas, até porque sua criação tardia, precedida pela venda de quatro empresas estatais, demonstrava o descaso com o estabelecimento de regras e diretrizes que deveriam ser seguidas por estas concessionárias. ${ }^{58} \mathrm{O}$ então fracasso das privatizações, atribuído anteriormente quase exclusivamente à inação das empresas, passa a ter sua culpa dividida com o Estado, que até mesmo teve toda a responsabilidade em seus ombros, confirmada pela demora em apresentar a agência regulatória. ${ }^{59}$

A presença tardia de uma agência regulatória para o setor energético nacional teve conseqüências em curto prazo que alteraram o panorama da geração de eletricidade, principalmente nas região sudeste do país. Com as privatizações houve a desarticulação das companhias energéticas e o fim do planejamento integrado, levando alguns anos depois do fim dos leilões das estatais, em 1997, ao colapso do sistema com um acontecimento chave para os rumos que tomaram a matriz energética nacional e do Estado de São Paulo no século XXI: o “apagão”.

Esse acontecimento é considerado aqui significativo para a temática, pois levou à criação pelo Governo Federal de um programa de incentivo para as fontes alternativas, e também pode ser considerado como um reflexo do uso extensivo de duas fontes energéticas, hidroelétricas e petróleo, conseqüentemente gerando a dependência destas na matriz energética nacional.

\footnotetext{
${ }^{58}$ Cf. BERMANN, Célio. Energia no Brasil: para quê? para quem? Crise e alternativas para um país sustentável. São Paulo: Editora da Livraria da Física/FASE, 2001.

${ }^{59}$ Idem.
} 
O fenômeno do "apagão", ocorrido em 11/03/1999, pode ser considerado como um divisor de águas no sistema energético nacional, pois demonstrou a ineficiência dos planejamentos energéticos, a dependência da matriz baseada nas hidrelétricas, e conseqüentemente no regime das chuvas. Colocaram-se em evidência também as privatizações das concessionárias elétricas do país, pois a desarticulação do sistema nacional, provocada pelos leilões de energia, levou à bancarrota de toda a matriz elétrica. Em 2000, um ex-membro dos quadros públicos, Dr. Joaquim Francisco de Carvalho, que havia sido diretor da Companhia Energética de São Paulo (CESP), fez uma observação sobre a postura das concessionárias, antes das privatizações, em uma sessão na Câmara dos Deputados:

Por isso, as empresas elétricas públicas reservam fatias importantes de seus orçamentos para investimentos dessa natureza. Era assim que faziam a Cesp, a CPFL e a Eletropaulo. A Cesp, por exemplo, investia somas altíssimas na preservação dos reservatórios das suas hidroelétricas, das orlas desses reservatórios em programas de ictiologia, produção e até em parque ecológico. Até isso a Cesp tinha. Qual o empresário que vai tirar do seu lucro para investir nisso? ${ }^{60}$

O baixo nível nas barragens das hidrelétricas, acentuado pelo período de estiagem, levou ao colapso do abastecimento de indústrias, comércio e residências. Inicialmente, a ANEEL procurou culpar raios que teriam caído em uma das centrais de distribuição, localizada em Bauru; porém, o sistema meteorológico nacional constatou que não ocorreram raios nesta região no horário do blecaute. ${ }^{61} \mathrm{Com}$ base nas informações que foram posteriormente divulgadas, o especialista em energia Luis Pinguelli Rosa foi levado a concluir sobre o acontecimento o seguinte: "Consta que o blecaute resultou da queda de uma subestação da CESP, em Bauru, que conecta as

\footnotetext{
${ }^{60}$ CÂMARA DOS DEPUTADOS. Colapso energético no Brasil e alternativas futuras. Brasília: Câmara dos Deputados/Coordenação de Publicações, 2001. p. 33.

${ }^{61}$ Cf. ROSA, Luiz Pinguelli. O apagão: por que veio? Como sair dele? Rio de Janeiro: REVAN, 2001.
} 
usinas do complexo de Urubupungá, causando uma oscilação no sistema elétrico. Este com pouca reserva de geração [...]." 62

O desenrolar deste acontecimento não se deu somente pela falta de eletricidade durante o blecaute, mas sim por uma medida que o Governo Federal e as companhias de energia tomaram para evitar novas crises no abastecimento energético. Em junho do ano de 2001, foi criado o Programa Emergencial de Redução de Consumo de Energia Elétrica, o "imposto do apagão", cujo objetivo era de, mediante a tributação do consumidor final, promover a redução da demanda energética e, conseqüentemente, o alívio para a matriz geradora nacional, sendo que o prazo final se daria em 2002. Além disso, em Abril de 2002 foi criado o Programa de Incentivo às Fontes Alternativas de Energia Elétrica (PROINFA), que procurava inserir novas fontes à matriz nacional para auxiliar no momento de crise do abastecimento e, ao mesmo tempo, abrir um novo cenário de utilização destas fontes no mercado de energia do país. O texto de lei que cria este Proinfa é particularmente interessante para nós, pois aparece como um contraponto ao que os pesquisadores do PIPGE divulgaram e afirmaram em seus textos. $^{63}$

A chamada "recomposição tarifária" previa dois índices de aumento na conta de energia elétrica para determinados consumidores finais: 2,9\% para as chamadas Classes Residenciais - B1 e Rural - B2, e 7,9\% para os demais consumidores. ${ }^{64}$ Não se enquadrando os consumidores de baixa renda, portanto, o programa pretendia ser direcionado aos usuários do sistema que fossem significativos em sua demanda da energia elétrica e que pudessem nesse sentido contribuir com a redução no

\footnotetext{
${ }^{62}$ Idem. p. 85.

${ }^{63}$ Como base para a compreensão das medidas e leis que definiram o Programa Emergencial de Redução de Consumo de Energia Elétrica e Proinfa, utilizei a Medida Provisória No. 14 de 21 de Dezembro de 2001; Resolução No. 91, de 21 de Dezembro de 2001 e a também a Lei No. 10.438, de 26 de Abril de 2002.

${ }^{64}$ Resolução No. 91, de 21 de Dezembro de 2001.
} 
abastecimento de eletricidade nacional. Esta resolução partiu da recém criada Câmara de Gestão da Crise de Energia Elétrica (CGE), que a considerava como integrante do "[...] esforço para a revitalização do modelo do setor elétrico e a continuidade de investimentos nesse setor, de cuja regularidade depende o desenvolvimento do país." ${ }^{65}$, portanto, buscava-se recuperar o modelo que este mesmo governo montou, privatizado e de livre mercado. Esta "recomposição tarifária" tinha prazos distintos para cada região do país: seis meses para os Estados do Pará e Tocantins, indo até 31 de dezembro de 2001 e uma data indefinida para as regiões Sudeste, Centro-Oeste e Nordeste, sendo que o prazo final iria até a extinção do programa, não fazendo parte da tarifação as regiões Sul e Norte. ${ }^{66}$

Esta taxa que estimularia o racionamento de energia teve resultados favoráveis para o Estado de São Paulo, sendo comemorado inclusive pelo BEESP de 2002, ${ }^{67}$ como resultado da "[...] consciente participação de toda a sociedade, no atendimento às medidas de racionamento." 68 Dentro desta perspectiva, a postura dos consumidores frente ao programa de racionamento pode ser considerada limitada. Isto ocorreu desde seu princípio pela própria estrutura em que o parque energético nacional se configurou a partir de 1995 com as privatizações, pois, se o apagão de 1998 foi um resultado direto da desarticulação entre as companhias, a proposta de diminuir a demanda de energia também teria um caminho difícil pela frente por conta deste fato. "A desverticalização das empresas elétricas, provocando a separação das atividades de geração, transmissão e distribuição de eletricidade [...]", escreve Célio Bermann, "[...] tornou

\footnotetext{
${ }^{65}$ Idem.

${ }^{66}$ Idem.

${ }^{67}$ SÃO PAULO (Estado); Secretaria de Energia. Balanço energético do Estado de São Paulo 2002: Ano base: 2001. São Paulo: CESP, 2002.

${ }^{68}$ Idem.
} 
mais difícil a adoção de programas de conservação." ${ }^{69}$, programas que vinham sendo implantados de forma conjunta pelas companhias sob controle estatal, o chamado Planejamento Integrado de Recursos (PIR). Mas eles foram deixados de lado quando se deram as privatizações. ${ }^{70}$

Com isto, verifica-se que o Programa de Racionamento de Energia Elétrica, que teria sido bem sucedido, como afirmam os documentos oficiais do Estado de São Paulo, se deu por conta da obrigatoriedade nas medidas de conservação, não por políticas públicas que tornassem eficientes a busca por equipamentos e o racionamento como práticas cotidianas da população. Isto pode ser confirmado, seja pelo fato já exposto de não existirem ou terem sido desarticulados os programas de conservação após as privatizações, ou então ao se analisar os índices de demanda de energia num Estado como o de São Paulo.

Em 2004 o Estado de São Paulo apresentou um crescimento de aproximadamente $7,0 \%$ do consumo total de energia em relação a 2003 , impulsionado pelo aumento do PIB do Estado na faixa de 7\%, superior ao nacional que obteve 4\%, um crescimento considerável, e que corrobora com o que foi dito aqui, pois, em 2000, durante o período em que ainda havia o perigo de outro blecaute e um ano antes do Programa de Racionamento ser acionado, houve o decréscimo de 4\% no consumo de energia, e no ano seguinte, 2001 , tivemos uma variação de $0,0 \%$ do total consumido, e a volta do crescimento da demanda, com $0,8 \%$ para 2002 e $2,0 \%$ em 2003 , quando o racionamento havia sido extinto. Portanto, uma variável que teve a contribuição "consciente" do cidadão somente no momento em que foi cobrado para isso, quando se encerrou o imposto sobre a conta de eletricidade, voltaram a manter as taxas de utilização, chegando até o pico de 2004, com um aumento considerável e comemorado

\footnotetext{
${ }^{69}$ BERMANN, Célio. Op. Cit. p. 51.

${ }^{70}$ Idem.
} 
pelo Estado de São Paulo. O que o trazia de volta aos níveis da década de 1990, quando em 1996 atingiu o aumento no consumo em relação a 1995 de $8,1 \%{ }^{71}$

Cabe agora analisar como foram criados cenários favoráveis, inclusive dentro das perspectivas apresentadas, para que a produção científica em energias alternativas tivesse condições de se realizar tanto no Brasil quanto no Estado de São Paulo.

\section{Conferências da ONU e as Energias Alternativas pós-1973}

Neste item serão abordados os cenários favoráveis criados para a pesquisa e desenvolvimento de energias alternativas em vários âmbitos: internacionais, nacionais e regionais. Ainda, estabelece-se a relação entre ciência e política que será fundamental para se compreender a produção científica do PIPGE, já que nas discussões sobre o tema, nas várias conferências, comissões e relatórios produzidos durante parte dos anos 1980 e 1990 até 2003, consta a atuação em conjunto de cientistas e políticos na formulação de planejamentos estratégicos para energia. O que irá ao encontro do conceito econômico e ecológico que entrava na pauta de muitos governantes no início do século XXI, o "Desenvolvimento Sustentável”.

No ano de 2002, ocorre em Joanesburgo, na África do Sul, o quarto encontro das Nações Unidas sobre meio ambiente. Este evento foi denominado de Rio +10 , numa alusão ao ocorrido na cidade do Rio de Janeiro em 1992. Ambas as reuniões foram marcadas por serem eventos de cúpula, ou seja, cujos participantes representavam os

\footnotetext{
${ }^{71}$ Cf. SÃO PAULO (Estado). Secretaria de Energia, Recursos Hídricos e Saneamento. Matriz energética do Estado de São Paulo 2006 a 2016. Série Informações Energéticas no. 006. São Paulo, 2005. A falta de precisão quanto ao dado do consumo de 2004 se dá pelo fato de que houve uma discrepância entre o valor apresentando pelo BEESP e pela Matriz Energética, isso quando ambos são publicações da mesma origem, a Secretaria de Energia, Recursos Hídricos e Saneamento do Estado de São Paulo.
} 
governos de seus países, além de proporcionarem reuniões paralelas com ONGs e especialistas nas áreas discutidas no Fórum.

A Rio +10 teve como principal objetivo realizar um balanço das ações que os participantes de 1992 empreenderam em seus países. Não foram feitos acordos da mesma ordem do que aqueles ocorridos durante a Rio-92, apenas estabeleceram intenções para os anos seguintes. Em certo sentido, a cúpula de Joanesburgo foi um encontro visando à reiteração do Protocolo de Kyoto de 1998, provavelmente o evento ambiental que reuniu a maior parte das nações do planeta. ${ }^{72}$ Neste Protocolo foram sugeridas soluções para a mitigação da emissão de gases poluentes na atmosfera, criando mecanismos de desenvolvimento limpo (MDL) e também o mercado de créditos de carbono, na tentativa de amenizar os graves problemas atmosféricos detectados por cientistas e organizações ambientalistas. O Protocolo de Kyoto foi ratificado por todas as nações presentes, menos o Japão e os EUA.

A assinatura, ou melhor, a existência de um "pacto" de caráter global como o de Kyoto significou muito mais que a conscientização dos governos quanto à questão ambiental e ao modelo desenvolvimentista adotado por muitos, pautado pela exploração dos recursos naturais, causando impactos profundos no meio ambiente. Representou também a necessidade premente de decisões amplas e em curto prazo para a resolução das diversas crises ambientais que se acentuaram a partir da década de 1970, curiosamente a década na qual surgem os movimentos ambientalistas e as primeiras pesquisas científicas de ampla divulgação sobre os prejuízos causados pela civilização capitalista ao mundo natural, seja em âmbito local, regional ou mundial.

Os anos 1970 começaram apresentando possibilidades futuras de alterações significativas no modo de vida ocidental, tanto pelo aumento das discussões sobre o

\footnotetext{
${ }^{72}$ CÚPUlA MUNDIAL sobre DESENVOLVIMENTO SUSTENTÁVEL. Relatório da delegação do
} Brasil. Brasília: Fundação Alexandre de Gusmão, 2004. 
meio ambiente no âmbito social e político, com a publicação de várias obras sobre a relação entre ser humano e natureza, quanto pela primeira reunião das Nações Unidas sobre Meio Ambiente e Desenvolvimento no ano de 1972 em Estocolmo na Suécia. Estes fatores pareciam impulsionar um período de reflexão sobre a ação humana junto aos recursos naturais, essenciais à continuidade do crescimento econômico do período. Isto também concretizou, principalmente após o choque do petróleo em 1973, a abertura para uma renovação em larga escala da matriz energética mundial, aliada à idéia de energias alternativas como respostas ao problema energético e ambiental do planeta.

De uma maneira geral, as alternativas serviam de síntese aos questionamentos e críticas dos ambientalistas por uma relação entre homem e meio ambiente que fosse menos impactante para este último. As energias alternativas eram apresentadas como ecologicamente viáveis, por diminuírem o impacto da geração de energia sobre a natureza, e, no lado econômico, pela possibilidade de manterem o desenvolvimento das forças produtivas do capital nos níveis desejados.

As características da matriz energética, tanto no Brasil quanto no resto do Ocidente, baseadas no petróleo e na eletricidade, tendo a energia nuclear despontando como uma fonte para o futuro, mantiveram-se inalteráveis no início da década de 1970 , especificamente até os primeiros meses de 1973. Neste ano, os países exportadores de petróleo, associados sob a égide da Organização dos Países Exportadores de Petróleo $(\mathrm{OPEP}){ }^{73}$, decidem pela diminuição da produção do óleo, gerando o aumento do preço do barril no mercado energético, provocando o chamado "Choque" do petróleo. Os barris aumentaram dos habituais US\$ 2,14 - preço mantido desde o final da Segunda Guerra Mundial - para US\$ 12 dólares e, meses depois, atingiram a cifra de US\$ 30,13

\footnotetext{
${ }^{73}$ Entidade, que é formada em sua maioria por países árabes, detinha e ainda detém o controle da maior parte das reservas de petróleo conhecidas no planeta, administrando, portanto, o transporte e refino do produto para a venda no comércio mundial. (Cf. LUCIANI, Giacomo. A OPEP na economia mundial. In: Encontros com a Civilização Brasileira. N. 16, Out, 1979. pp. 27-39)
} 
dólares o barril; ou seja, o preço se multiplicou, onerando o caixa dos países importadores, entre eles o Brasil.

Este acontecimento atingiu diretamente as nações industrializadas, extremamente dependentes do petróleo para o andamento de suas atividades econômicas, além de afetar mais incisivamente as nações em processo de industrialização, como o Brasil. Tal fato criou incertezas quanto ao futuro energético do mundo, principalmente em relação à continuidade da matriz baseada em combustíveis fósseis. Interessante notar que, apesar da crise energética e pelo fato que o país era um dos maiores importadores de petróleo, o discurso oficial brasileiro, discurso proveniente dos militares, referente a este período costuma exaltar a capacidade do país em "driblar" a crise energética, pela possibilidade que teria de substituir o combustível pelo álcool de cana-de-açúcar. ${ }^{74}$

O clima de incertezas quanto ao futuro energético baseado nos combustíveis fósseis após 1973 era corroborado por estudos anteriores a este período. Em 1968, um grupo de técnicos e especialistas de diversas áreas se reuniu com o objetivo de projetar para as décadas seguintes as possibilidades de crescimento econômico do planeta, levando em conta as reservas naturais disponíveis e conhecidas, assim como a capacidade do meio ambiente de se recuperar dos danos registrados no período. O “Clube de Roma', como ficou conhecido o grupo, foi patrocinado por empresários e industriais dos EUA e da Europa, se posicionando como:

[...] uma organização informal, descrita, com muita propriedade, como um 'colégio invisível'. Suas finalidades são promover o entendimento dos componentes variados, mas interdependentes - econômicos, políticos, naturais e sociais - que formam o sistema global em que vivemos; chamar a atenção dos que são responsáveis por decisões de

\footnotetext{
${ }^{74}$ PIETRE, Valdir. Proálcool: legislação, ecologia e questão social. In: Encontros com a Civilização Brasileira. V. 26, 1980. pp. 59-78
} 
alto alcance, e do público do mundo inteiro, para aquele novo entender, e, assim, promover novas iniciativas e planos de ação. ${ }^{75}$

O "Colégio Invisivel", na sequência dos trabalhos, formulou um modelo de análise dos dados, utilizando computadores para a criação de cenários futuros, tendo como finalidade a investigação de certas tendências globais: "[...] o ritmo acelerado de industrialização, o rápido crescimento demográfico, a desnutrição generalizada, o esgotamento de recursos naturais não-renováveis e a deterioração ambiental [...]." 76

Ao final publicam um relatório intitulado "Limites do Crescimento". A obra, organizada por Dennis e Dornella Meadows, professores do MIT, concluiu, entre outros pontos, que as reservas conhecidas e economicamente viáveis de petróleo e carvão se esgotariam em 50 anos. ${ }^{77}$ Além desta constatação os cientistas do grupo, ao calcularem as taxas de poluição atmosférica, anunciaram como resultado que a vida sob a superfície terrestre estaria prejudicada ou até mesmo extinta nos cem anos seguintes à publicação, desde que os níveis de emissão dos gases poluentes não fossem diminuídos a tempo. Isto sem levar em conta os problemas demográficos, com o aumento exponencial da população mundial para a virada do século, as epidemias de doenças, agravadas pelas péssimas condições de saúde dessas pessoas, e a possível crise de alimentos, com a diminuição de terra férteis para o plantio, causada pelo esgotamento dos solos cultivados por monoculturas e pela distribuição dos alimentos produzidos, centrada nas nações ricas do planeta. ${ }^{78}$

O tema do esgotamento do petróleo e as questões ambientais que suscitava seria assunto também, no ano de 1972, na Conferência das Nações Unidas em Estocolmo. Entretanto, é importante ressalvar que, neste contexto, as fontes fósseis já tinham sido

\footnotetext{
${ }^{75}$ MEADOWS, Dennis Et. Al. Limites do Crescimento. São Paulo: Editora Perspectiva, 1973. p. 09-10.

${ }^{76}$ Idem p. 18.

${ }^{77}$ Ibidem.

${ }^{78}$ Ibidem.
} 
responsabilizadas, seja pelos governos ou então por grupos ecologistas, pelos danos ambientais, tal constatação já fora anunciada pelo Clube de Roma em seu relatório.

O problema era que, apesar de os técnicos do Clube afirmarem, em relação a poluição atmosférica, que: “[...] A fonte deste aumento exponencial de $\mathrm{CO}_{2}$ atmosférico é o uso crescente pelo homem, de combustíveis fósseis [...]" ${ }^{79}$, ainda não dispunham de instrumentos para qualificar e quantificar a poluição no ambiente global:

[...] Só muito recentemente o homem tem-se preocupado com os efeitos de suas atividades sobre o meio ambiente. As tentativas científicas de medir tal efeito são ainda mais recentes e muito incompletas. Seguramente, não somos capazes, agora, de chegar a uma conclusão final sobre a capacidade que a terra tem de absorver a poluição [...]. ${ }^{80}$

Nesta mesma década, as fontes alternativas de energia ${ }^{81}$ vinham sendo questionadas, pelos governos e as sociedades, quanto à possibilidade de serem utilizadas como principal recurso energético das nações, principalmente dos Estados Unidos da América e países da Europa; uma conjuntura em que as tecnologias ambientalmente “saudáveis" se tornaram o foco de grupos ambientalistas, cientistas e políticos na tentativa de amenizar as causas da poluição no planeta. Mas nem todas as fontes alternativas detêm o mesmo apelo ambiental; cada tecnologia apresenta questões intrínsecas a seu funcionamento.

Deve-se notar que, para cada tipo de fonte energética, há diferentes tipos de tecnologias, processos de obtenção e custos, além das questões ambientais envolvidas. ${ }^{82}$

\footnotetext{
${ }^{79}$ Ibidem, p.66.

${ }^{80}$ Ibidem, p. 67.

${ }^{81}$ Como fontes alternativas de energia entendo aquelas que são renováveis e com impacto ambiental praticamente nulo; destaco: a solar e suas variáveis, biomassa, eólica, geotérmica.

82 "As fontes renováveis são representadas por uma diversificada coleção de tecnologias, cada uma tendo características e custos diferentes para a produção de eletricidade. Algumas estão em processo de desenvolvimento técnico e são menos competitivas que outras: a solar, por exemplo, é mais cara que a eólica e a geotérmica. Além disso, nem todas possuem os mesmos benefícios econômicos, sociais e ambientais. A utilização de biomassa envolve uma classe de produtores bem diferentes daquela que explora recursos hidrelétricos ou geotérmicos, por exemplo. Os impactos ambientais desses empreendimentos, embora bem menores quando comparados com as fontes convencionais (geração fóssil ou grandes hidrelétricas) são também muito diversos e muitas vezes podem ser significativos." (Cf.
} 
A nomenclatura utilizada para as fontes energéticas nesta dissertação variou nos últimos anos dentro do vocabulário de especialistas e do público em geral. Atualmente, o termo energias renováveis é o que abarca as formas energéticas que têm uma relação ecológica e também possibilitam a exclusão de fontes antes arroladas no conjunto, mas que não detêm a característica ambiental e, de certa forma, estão sendo incluídas na matriz energética usual, tais como o gás natural e a energia nuclear. Essa denominação passou a ser utilizada de forma mais comum nos meios acadêmicos e midiáticos no Brasil e nos outros países em meados da década de 1990. O termo é muitas vezes encontrado em associação ao "não convencional", o que permite a saída da hidroeletricidade. Sobra, então, a energia solar, geotérmica, maremotriz e eólica, e a biomassa e suas variantes, enquadradas sob a denominação "renováveis".

Energias Renováveis e não-convencionais foi uma opção também empregada para atuar diretamente sobre a denominação anterior "energias alternativas". Isso ocorre pela suposta associação do último termo com a noção de não preferencial, entretanto, disponível. A denominação "alternativas" enquanto opcionais à matriz tradicional baseada em combustíveis fosseis e não necessariamente como fontes viáveis para substituir o uso em larga escala desta matriz. Portanto, renováveis poderia representar uma imagem tanto de amadurecimento tecnológico, de modernidade, quanto de fontes não-poluentes. Interessante notar que, ainda hoje, o governo brasileiro classifica sua geração hidrelétrica, predominante no país desde 1960 e 1970, como uma fonte renovável, inserindo-a na lista das fontes de caráter ecológico.

A designação "renováveis" pode ainda ser encontrada em títulos de obras da área de energia, como, por exemplo, o livro do pesquisador na área de energia Gilberto

JANNUZZI, Gilberto De Martino. Politicas públicas para eficiência energética e renovável no novo contexto de mercado: uma análise da experiência recente dos EUA e do Brasil. Campinas: Autores Associados, 2000. p. 46. 
de Martino Jannuzzi, "Políticas públicas para eficiência energética e renovável no novo contexto de mercado: uma análise da experiência recente dos EUA e do Brasil", publicado no ano 2000. É comum também o uso do termo “outras fontes" em relatórios e balanços energéticos nacionais e estaduais no país, da década de 1990 principalmente, por determinar as fontes renováveis que tiveram pequena porcentagem de utilização na matriz. ${ }^{83}$

Já "alternativas" foi praticamente deixada de lado na literatura científica no final dos anos 1990, tendo suas origens na década de 1970. Com a "crise energética" provocada pela alta nos preços dos barris de petróleo, o chamado "choque do petróleo" de 1973, e também por conta da enorme quantidade de poluição atmosférica causada por este produto e pelos demais combustíveis fósseis, no caso, o carvão, surge em meios científicos, políticos e principalmente ecologistas a proposição do uso de fontes que fossem alternativas a esta matriz fóssil. Tal atitude possibilitaria a diminuição da dependência dos países importadores do óleo combustível, além de amortecer os índices de poluição por eles geradas. $\mathrm{O}$ termo fez parte de forma incisiva na literatura sobre $\mathrm{o}$ assunto até meados da década de 1990.

No Brasil, antes de 1970, havia também a designação de "não-comerciais" para formas energéticas que não faziam parte da matriz por serem economicamente inviáveis. Especialmente, o álcool da cana de açúcar utilizado no país de forma contingencial durante a Segunda Guerra Mundial para suprir o petróleo direcionado para os esforços de guerra. Este combustível não foi mais utilizado ao final do confronto, principalmente pela normalização dos preços do petróleo no mercado

\footnotetext{
${ }^{83}$ Cf. São Paulo (Estado). Secretaria de Estado de Energia. Balanço Energético do Estado de São Paulo 1995. Ano Base: 1994. CESP: São Paulo, 1995. E demais balanços da série, que vai desde 1991 a 2008.
} 
internacional, que o tornavam mais dispendioso que o óleo. ${ }^{84}$ Ainda podemos encontrar o termo no relatório da Comissão de Desenvolvimento e Meio Ambiente para a América Latina e Caribe do ano de 1993, utilizada para designar fontes como a lenha, que são recolhidas "livremente" para uso doméstico. ${ }^{85}$

Seja qual for a designação dada para as fontes alternativas, no período de 1992 a 2002, elas faziam parte de maneira marginal da matriz energética mundial. Dentro desta perspectiva, as fontes de energia do período contemporâneo podem ser divididas em dois grupos principais. Em um grupo, podemos arrolar as formas tradicionais, que são predominantes na matriz energética. Elas são formadas basicamente pelos combustíveis fósseis produtores de energias primárias: petróleo, carvão, gás natural e também, no caso brasileiro, as hidrelétricas, e por fontes secundárias de energia: energia elétrica, vapor, gasolina e as termoelétricas. No outro grupo, as fontes que podemos denominar de não-tradicionais ou alternativas, compostas por primárias: energia solar, geotérmica, maremotriz, eólica e a biomassa. ${ }^{86}$

$\mathrm{O}$ apelo à pesquisa e desenvolvimento dessas fontes tinha como principal foco a independência dos países desenvolvidos do petróleo árabe, já que haviam sofrido um forte embargo e aumento sensível de preços no período de 1970. Dessa forma, reaparecem as energias alternativas como solução do problema econômico, sendo que as questões ecológicas inerentes a elas eram secundárias; essas questões não tinham a mesma importância para os governos nesse período como poderemos observar na década de 1990 e, ainda mais, atualmente.

${ }^{84}$ CALABI, André Sandro et. al. A energia e a economia brasileira: interações econômicas $e$ institucionais no desenvolvimento do setor energético no Brasil. São Paulo: Pioneira: Fundação Instituto de Pesquisas Econômicas, 1983.

${ }^{85}$ COMISSÃO DE DESENVOLVIMENTO E MEIO AMBIENTE DA AMÉRICA LATINA E CARIBE. Nossa própria agenda. Banco Interamericano de Desenvolvimento: Programa das Nações Unidas para o Desenvolvimento, 1989.

${ }^{86}$ As fontes de energia primária são aquelas que geram energia diretamente da matéria-prima em estado natural, não necessitando de nenhum processo para a tal finalidade. Já as formas secundárias produzem energia tendo como base a energia primária. 
O empecilho maior para a introdução de tais fontes era seu custo; por ser economicamente inviável sua aplicação, compensaria aos interessados encontrarem outros mecanismos para a questão do petróleo, sendo que a tecnologia das alternativas foi relegada para o futuro, como afirma o documento oficial de Estocolmo:

[...] Outras tecnologias não-poluentes, tal como a energia originária das marés ou a energia termal ou solar, podem ser usadas e possivelmente incrementadas. Contudo pouca gente as considera como disponíveis em grau importante nas próximas décadas $[\ldots]^{87}$

Não disponíveis para os próximos anos, as tecnologias "não-poluentes" acabaram em segundo plano na década de 1980. Ao mesmo tempo, o consumo das fontes tradicionais de energia, como o petróleo, o carvão e o gás natural aumentaram significativamente ao redor do planeta e, paralelamente, houve crescimento das taxas de poluição em vários países, principalmente nos mais industrializados. ${ }^{88}$

Estas constatações, alertadas tanto no relatório do Clube de Roma quanto em Estocolmo no ano de 1972, somam-se a outros problemas ambientais observados na utilização das fontes energéticas fósseis como também na insurgente energia nuclear. Basta pensar nos desastres radioativos de Three Mile Island nos EUA, nos anos 1950, ou Chernobyl em 1986; ou nos constantes derramamentos de petróleo nos oceanos pelos acidentes no transporte do produto. Como exemplos podem-se citar o choque do petroleiro Urquiola num porto espanhol em maio de 1976, jogando cinqüenta mil toneladas de petróleo bruto no mar; a causa foi o excesso de carga que fez o navio raspar o fundo do canal. Em 1967, o Torrey Canyon bate nos recifes na Cornualha, despejando cento e dezessete mil toneladas de petróleo do Kuwait. No mais, a maneira de evitar uma tragédia maior leva aos oceanos toneladas de produtos químicos

\footnotetext{
${ }^{87}$ WARD, Bárbara e DUBOS, René. Uma terra somente: a preservação de um pequeno planeta. São Paulo: Edgar Blucher/Melhoramentos/Ed. da Universidade de São Paulo, 1973. p. 91

${ }^{88}$ MARTIN, Jean-Marie. A economia mundial de energia. São Paulo: EDUNESP, 1992.
} 
utilizados para conter o alastramento da mancha de óleo, o que também prejudica a fauna e a flora marinha. ${ }^{89}$

Na década seguinte, anos 1980, com a estabilização dos preços dos barris de petróleo no mercado internacional, não foi alterado o que vinha sendo desenvolvido e utilizado na conjuntura encontrada na década anterior; ou seja, pouca ou mesmo nenhuma mudança pode ser observada em relação à pesquisa sobre energias alternativas. As tecnologias disponíveis ainda não forneciam a confiança necessária para a utilização dessas formas de energia, seja pela baixa estocagem ou pelas dificuldades em transportá-las. ${ }^{90}$

No entanto, este período manteve a discussão sobre os problemas ambientais em destaque entre organismos internacionais, até mesmo popularizando o tema. Isso permitiria um novo impulso para a pesquisa de fontes alternativas na década de 1990 , pois a referência sobre energia se manteve na pauta das discussões. O Brasil se torna, inclusive, um propositor de medidas para a adoção de "energias alternativas" no cenário mundial, tal como ocorreu durante a Cúpula da ONU de 2002.

A delegação enviada para representar o Brasil na Conferência da ONU de 2002, a já referida Rio+10, teve a participação do Professor do PIPGE, José Goldemberg. Ele foi incumbido de formalizar uma proposta brasileira para a questão energética dentro do fórum de discussões. A intervenção de Goldemberg se direcionou no sentido de apresentar durante o plenário da Iniciativa Brasileira de Energia, a sugestão do país para que houvesse uma meta mundial para 2010, no que diz respeito à introdução de fontes renováveis de energia na matriz global, da ordem de $10 \%$ do total gerado no planeta. ${ }^{91}$ Um avanço considerável, já que na mesma reunião dez anos antes nenhuma

\footnotetext{
${ }^{89}$ TARADE, Guy. O livro negro da poluição. Lisboa: Bertrand, 1980.

${ }^{90}$ MARTIN, Jean-Marie. Op. cit. 1992.

${ }^{91}$ Cúpula Mundial sobre Desenvolvimento Sustentável. Op. cit. p. 64.
} 
meta neste sentido havia sido traçada. Porém, subentende-se também que, se houve a necessidade de se estabelecer porcentagem para implementação das energias alternativas no futuro da matriz energética mundial, isto ocorreu pelos percursos que estas fontes passaram ao longo dos anos 1990, significativamente desde a reunião de 1992 no Rio de Janeiro, quando houve uma orientação abrangente para as pesquisas dessas fontes, criando um clima de probabilidades na aplicação no cenário energético de diversos países, inclusive o Brasil.

As expectativas no início da década de 1990 sobre pesquisa em tecnologia de energias alternativas e sua utilização na matriz energética de diversos países estavam presentes durante a Conferência da ONU sobre Meio Ambiente e Desenvolvimento (CNUMAD), realizada na cidade do Rio de Janeiro em 1992, a conhecida ECO-92. As equipes de trabalho da cúpula mundial procuravam abordar os vários temas ambientais que o mundo enfrentava, elaborando ao final da reunião um documento que trazia as conclusões e as perspectivas de todas as áreas discutidas durante o encontro. Este documento, a Agenda 21, serviria para os governos dos países envolvidos como uma fonte de consultas e um programa para a resolução de seus problemas ambientais tanto locais quanto regionais, promovendo a melhoria qualitativa do ambiente global.

O resultado mais significativo da ECO-92, a Agenda 21, exortava políticas de desenvolvimento sustentável, criando um pacto entre os países participantes, com metas a serem cumpridas em relação à redução de danos ambientais que suas economias vinham causando. ${ }^{92}$

Com a preocupação ambiental na pauta de muitos governos, 179 países assinaram o tratado de 1992. As políticas públicas para o desenvolvimento sustentável, que foram o principal termo da Agenda 21, focalizaram diversos temas que envolviam (CNUMAD). Agenda 21. 3ed. Brasília: Senado Federal, Subsecretaria de Edições Técnicas, 2003. 
questões ambientais; saneamento básico, transportes, reflorestamento, poluição e também a energia, propondo inclusive a pesquisa e desenvolvimento de energias alternativas. $^{93}$

Neste contexto, o papel da ciência e da tecnologia ganhava um destaque especial nas propostas para solucionar os problemas ambientais em discussão na $E C O-92$ e conseqüentemente na Agenda 21. A ciência vista como capaz de equacionar e responder aos questionamentos sociais deveria "[...] oferecer informações para permitir uma melhor formulação e seleção das políticas de meio ambiente e desenvolvimento no processo de tomada de decisões [...] ${ }^{\prime 94}$ Assim, ficou a encargo dos governos:

[...] desenvolver o conhecimento científico, melhorar as avaliações científicas de longo prazo, fortalecer as capacidades científicas em todos os países e fazer com que as ciências respondam às necessidades que vão surgindo. ${ }^{95}$

A ciência e a tecnologia ficaram diretamente responsáveis por dotar as sociedades de informações e tecnologias para solucionar os problemas ambientais que estas enfrentavam, entre eles, a questão energética, que contava com as diretrizes estabelecidas pela Agenda 21 e que deveriam ser seguidas pelos pesquisadores interessados em desenvolver as fontes energéticas, compreendidas como: “[...] essencial para o desenvolvimento social e econômico e para uma melhor qualidade de vida [...]" e também: "[...] Todas as fontes de energia deverão ser usadas de maneira a respeitar a atmosfera, a saúde humana e o meio ambiente como um todo." 96

Com estas questões em pauta, houve um crescimento no uso de energias alternativas e, conseqüentemente, a pesquisa e o desenvolvimento (P \& D) dessas fontes deveriam ser estimulados, além das medidas de conservação e maior eficiência energética nos equipamentos industriais, por usuários domésticos e demais formas de

\footnotetext{
${ }^{93}$ CNUMAD, op. cit.

${ }^{94}$ Idem. p. 519

${ }^{95}$ Idem.

${ }^{96}$ Idem. p. 138.
} 
consumo de energia. Esses últimos pontos são normalmente associados às fontes energéticas alternativas por preverem a redução do consumo, ou mesmo, a desaceleração do crescimento da demanda energética ao redor do planeta.

O estímulo partiria de organismos governamentais e também de empresas privadas. A Agenda 21 trazia em seu texto medidas para que governos, setor privado e demais interessados estimulassem a diversificação da matriz energética, apontando como função desses:

[...] Cooperar na identificação e desenvolvimento de fontes de energia renováveis e ambientalmente saudáveis para promover a disponibilidade de maiores suprimentos de energia, como apoio aos esforços em favor do desenvolvimento sustentável, em especial nos países em desenvolvimento. ${ }^{97}$

Dessa maneira, a Agenda 21 uniria aos esforços de cientistas, mediante a P \& D de fontes de energia menos poluentes e renováveis, também os esforços dos governos, por meio de políticas públicas, financiamento e o estímulo a mudança da matriz energética, e do setor privado pela procura em utilizar as energias alternativas nas residências, comércio, indústria e automóveis.

Diante do cenário que se esboçava após a ECO-92, confirma-se que o início da década de 1990 exibia um contexto favorável à disseminação das fontes alternativas de energia, com perspectivas de aumento considerável no uso de determinadas energias renováveis, tal como a solar, a biomassa e a eólica. Num livro publicado em 1992, JeanMarie Martin dá indícios da expectativa para a década em relação à exploração das energias renováveis:

No total, a exploração dos recursos renováveis, no estado atual das técnicas, poderia chegar até 5 Gtep por ano, ou seja, dois terços do consumo total de energia do mundo em 1990: 60\% viriam da biomassa; $30 \%$ do hidráulico e $10 \%$ do solar, dos eólicos e da geotermia. $\mathrm{Na}$ escala de certos países, estas últimas contribuições poderiam atingir proporções muito mais elevadas. ${ }^{98}$

\footnotetext{
${ }^{97}$ CNUMAD, op. cit, p. 138.

${ }^{98}$ Martin, Jean-Marie. Op. cit, pg. 117. (Gtep = Giga Toneladas Equivalentes de Petróleo)
} 
O autor afirma ainda a necessidade de fontes energéticas que garantam a sustentabilidade do desenvolvimento econômico e também do equilíbrio ambiental, e que estes quesitos estariam garantidos por novas técnicas de utilização e produção de energia. Mais uma vez, a ciência e a tecnologia, com o auxilio dos governos e de órgãos financiadores, deveriam assumir a dianteira na pesquisa e desenvolvimento de energias alternativas. $^{99}$

Anteriormente à reunião de 1992, houve a publicação de relatórios preliminares, como a "Nossa Própria Agenda" da Comissão de Desenvolvimento e Meio Ambiente da América Latina e Caribe e, posteriormente à Cúpula, a "Agenda 21 Paulista” do Estado de São Paulo. O primeiro tratou de fazer um levantamento dos principais problemas ambientais e de desenvolvimento ocorridos na América Latina. Já o segundo foi um relatório das atividades previstas na Agenda 21 e executadas no estado de São Paulo nos anos que se seguiram à Cúpula. Ambos os documentos são importantes, pois definem as diretrizes que a ciência e a tecnologia em energia seguiram na pesquisa sobre as fontes alternativas, e também por terem o pesquisador José Goldemberg, professor do PIPGE, incluído nas equipes de confecção e análise dos dados. No entanto, as orientações maiores para estes documentos, inclusive a Agenda 21 de 1992, viria de um documento anterior, também da ONU, resultado de trabalhos realizados durante a década de 1980, o "Relatório Brundtland".

Em 1988, a Organização das Nações Unidas publicou um relatório proveniente da Comissão Mundial para o Meio Ambiente e Desenvolvimento. Vinculada à Organização das Nações Unidas (ONU) e presidida por Gro Harlem Brundtland (daí muitos denominarem o relatório da comissão como "Relatório Brundtland”), tendo sido criada em 1983, seu objetivo maior era "Uma agenda global para mudança", tendo

\footnotetext{
${ }^{99}$ Martin, Jean-Marie. Op. cit.
} 
como metas formular estratégias que visavam incluir as questões ambientais no planejamento governamental de vários países. ${ }^{100}$ No relatório, resultado de reuniões com especialistas de diversas áreas do conhecimento e realizadas em países membros da ONU, havia o objetivo de analisar a situação do meio ambiente global, mediante consultas regionais e locais, propondo possíveis rumos para solucionar a crise ambiental detectada anos antes pelos meios científicos e divulgada por entidades ambientalistas ao redor do planeta. No quesito energia, o relatório previa que:

Uma nova era de crescimento econômico deve, portanto, consumir menos energia que o crescimento passado. As políticas de rendimento energético devem ser a pedra-de-toque das estratégias energéticas nacionais para um desenvolvimento sustentável, e há muitas possibilidades de melhoria neste sentido [...]. ${ }^{101}$

A Comissão Brundtland iniciava a conjunção entre a questão energética e a preocupação com o crescimento econômico das nações. Assim procurava estabelecer metas de desenvolvimento que visavam à sustentabilidade do sistema econômico e dos recursos naturais utilizados pelas nações na produção de energia.

Os limites extremos do desenvolvimento global talvez sejam determinados pela disponibilidade de recursos energéticos e pela capacidade de biosfera de absorver os subprodutos do uso de energia. Esses limites energéticos podem ser atingidos muito mais depressa do que os limites impostos por outros recursos materiais. Primeiro, há problemas de abastecimento: o esgotamento das reservas de petróleo, o alto custo e o impacto ambiental da mineração de carvão, e os riscos da tecnologia nuclear. Segundo, há problemas de emissão, especialmente a poluição ácida e o acúmulo de dióxido de carbono, que causam o aquecimento da terra. ${ }^{102}$

A Comissão reafirmava a relação do uso dos combustíveis fósseis como agentes causadores da poluição atmosférica, da mesma forma que a conferência da ONU de 1972 o fez. E ainda, relacionava os problemas de abastecimento destas fontes que invariavelmente se esgotariam num período de tempo curto. A Comissão Brundtland

\footnotetext{
${ }^{100}$ Cf. COMISSÃO MUNDIAL SOBRE MEIO AMBIENTE E DESENVOLVIMENTO. Nosso futuro comum. Rio de Janeiro: Editora da Fundação Getulio Vargas, 1988.

${ }^{101}$ Idem. p. 16.

${ }^{102}$ Idem. p. 63.
} 
definia as perspectivas de um novo quadro energético a ser criado para os anos seguintes e, incisivamente, para o século XXI.

A Comissão acredita que deveria ser feito todo o esforço possível para desenvolver o potencial de energia renovável, que deverá constituir a base da estrutura energética do mundo do século XXI. E que se quiser que esse potencial seja plenamente aproveitado, é preciso um esforço conjunto muito maior $[\ldots] .{ }^{103}$

Estes pontos, discutidos também na reunião de 1992, apresentavam uma ressalva sobre as opções energéticas, que não foram questionadas na ECO-92. Para a Comissão nem mesmo as energias alternativas seriam uma possibilidade real, muito menos um recurso ecologicamente correto. As opções energéticas deveriam promover outros pontos considerados importantes para a sustentabilidade do planeta " [...] a sustentabilidade requer uma ênfase maior na conservação e no uso eficiente de energia." ${ }^{104}$ Além do fato de considerarem que:

[...] O desenvolvimento futuro depende indubitavelmente de que se disponha de energia por muito tempo, em quantidades cada vez maiores e de fontes seguras, confiáveis e adequadas ao meio ambiente. Hoje, não dispomos de nenhuma fonte - isolada ou combinada com outras - que possa atender a essa necessidade futura. ${ }^{105}$

O tom dado pela Comissão Brundtland, a ênfase na sustentabilidade do planeta frente ao crescimento econômico nos moldes tradicionais, junto à iniciativa de promover fontes energéticas que pudessem auxiliar no desenvolvimento sustentável, destoam em algumas partes do relatório da Comissão de Desenvolvimento e Meio Ambiente da América Latina e Caribe, principalmente no que tange a forma de crescimento almejada e as possibilidades energéticas em pauta nos países dessa região. Nesse documento, consideram inicialmente, no setor energético, que "[...] o baixo consumo per capita de energia na região - incluindo o consumo industrial - é uma

\footnotetext{
103 Idem. p. 217.

${ }^{104}$ Ibid. p. 63.

${ }^{105}$ Ibid. p. 186.
} 
manifestação concreta de nosso atraso econômico." ${ }^{106}$ Associando as noções de desenvolvimento divulgadas pelos países ricos ao uso da energia pelos vários setores da economia dos países latinos e caribenhos, chegam à conclusão que:

[...] A região tem grandes recursos não utilizados no campo energético. $\mathrm{O}$ enorme potencial hidrelétrico, e mesmo o petróleo, são parcialmente aproveitados. Usam-se muito pouco as fontes nãoconvencionais de energia (eólica, solar, de biomassa), e quase não houve progressos na exploração das possibilidades de conservação de energia em cada tipo de atividade. ${ }^{107}$

Não descartam as diversas fontes disponíveis, inclusive o petróleo, e de forma mais acintosa, a hidroeletricidade. No entanto, reconhecem que entre os principais problemas ambientais causados pelo uso dessas fontes, está a poluição do ar e das águas e a inundação de áreas férteis para a construção de barragens das usinas hidrelétricas. “[...] a política energética deve estar enquadrada na política mais ampla de utilização sustentável dos recursos naturais. Conseqüentemente, o organismo responsável pelo setor energético deve trabalhar em estreita cooperação com as autoridades ambientais." 108 Incentiva, neste caso, o aumento no uso da energia pela população, junto à adoção de fontes alternativas, e por fim, busca na ciência e tecnologia, tanto aquela importada quanto local, a solução para proporcionar a eficiência e a conservação energética nos equipamentos consumidores e na geração em larga escala de energia na região.

[...] temos de fundar nossas esperanças nos progressos tecnológicos alcançados pelos países desenvolvidos, que poderão ser de grande valia para nós. Ao mesmo tempo, a região precisa desenvolver suas próprias tecnologias para a produção e o consumo de energia, assim como criou seu próprio know-how em perfurações (Brasil), energia nuclear e hidrelétrica (Argentina) e usinas geotérmicas (México), entre outras. ${ }^{109}$

106 COMISSÃO DE DESENVOLVIMENTO E MEIO AMBIENTE DA AMÉRICA LATINA E CARIBE. Nossa própria agenda. Banco Interamericano de Desenvolvimento: Programa das Nações Unidas para o Desenvolvimento. 1989. p. 153.

${ }^{107}$ Idem. pp. 80-81.

${ }^{108}$ Ibid. p. 160.

${ }^{109}$ Ibid. p. 159. 
Novamente fica a cargo dos cientistas a resposta às questões energéticas, seja num âmbito global, regional ou local. As comissões internacionais, contando com a participação de cientistas e políticos, atuam no sentido de definir as diretrizes a serem seguidas pelos países interessados, cabendo aos cientistas desenvolverem os saberes e técnicas necessárias para suprir a forma de crescimento econômico desejável para o século XXI, o "Desenvolvimento Sustentável”. Mas como isto irá se concretizar nos anos seguintes? Houve a introdução de novas tecnologias energéticas? O caso do Estado de São Paulo pode elucidar alguns destes pontos.

No ano de 2003, a Secretaria de Estado do Meio Ambiente de São Paulo divulgou um relatório da chamada Agenda 21 paulista. Este documento tem sua importância para o contexto político e científico que está sendo tratado aqui pelo fato de apresentar as atitudes do Estado de São Paulo, principal palco de atuação do PIPGE no que tange a matriz energética estadual e a diversificação das fontes assim como proposta na Agenda 21 global e pela Comissão Latino-Americana e Caribenha.

Neste relatório, além das análises nas diversas áreas nas quais a preocupação ambiental estava presente. Em um dos capítulos, em que havia uma avaliação retrospectiva de 1985 até 2002, o relatório apresenta as mudanças na matriz energética do estado de São Paulo, principalmente em relação ao que considerava energias alternativas, como as hidrelétricas e a utilização da biomassa, além da pequena participação da energia solar.

Segundo o relatório, do total consumido de energia no Brasil no ano de 2000, o estado de São Paulo foi responsável por pouco mais de 1/4 (um quarto), mais especificamente $26,8 \%$ do consumo nacional de energia, de um total de 26 estados e o distrito federal. Consumo que ficou dividido da seguinte forma, segundo o relatório: “[...] Os setores mais significativos, no âmbito estadual, foram o industrial com 34,4\% 
e o de transportes, com 30,2\% do total. Nas últimas décadas, a utilização de energia em São Paulo passou por significativas alterações." O aumento do consumo energético de 1985 a 2000 correspondeu a $26 \%$, enquanto no resto do país este índice representou a metade, $13 \% .^{110}$

O relatório da Secretaria conclui que a cada ano se gasta mais energia com a produção dos mesmos produtos. O relatório também aponta os usos das fontes energéticas no estado, assim como os futuros planos de aproveitamento de cada uma das formas de energia. A biomassa e a energia solar estão presentes na análise. No caso da biomassa, o relatório afirma que:

O uso da biomassa favorece a geração descentralizada de energia e produz efeito positivo na criação de empregos, em especial no setor agrícola. O Estado de São Paulo, maior produtor de cana-de-açúcar do País, pode obter inúmeras vantagens energéticas, ambientais, econômicas e sociais dessa cultura [...]. ${ }^{111}$

Estimava-se que o potencial de uso da biomassa na cogeração pode alcançar até 3.095 MW, sendo que até o momento da publicação do relatório havia 140 usinas realizando o processo, totalizando $851 \mathrm{MW}$ de potência e $110 \mathrm{MW}$ de excedentes para a rede elétrica.

Diferentemente se apresenta a energia solar fotovoltaica, cujo uso ainda se restringe a pequenos sistemas e comunidades isoladas. No entanto, o relatório é otimista em relação ao potencial do estado na utilização desta fonte renovável, com o expressivo número de 1,2 bilhões de MW/ano. O relatório mostra a expectativa de uso da energia solar térmica, indicando que esta apresenta:

[...] A energia solar térmica apresenta tendência de maior expressividade na matriz energética paulista, especialmente na substituição dos sistemas convencionais de aquecimento de água. No horário de ponta os chuveiros elétricos representam, para o Estado,

\footnotetext{
${ }^{110}$ SÃO PAULO (Estado). Secretaria de Estado do Meio Ambiente. Agenda 21: a experiência paulista desde 1992. 2.ed. São Paulo:SMA, 2003. p. 24.

${ }^{111}$ Idem. p. 31.
} 
uma usina de $400 \mathrm{MW}$. Após a recente crise energética, o mercado de aquecedores solares apresentou considerável expansão. ${ }^{112}$

Vale ressaltar que esta expansão foi impulsionada também, como vimos, por uma crise energética de proporções nacionais, o chamado Apagão de 1999. Ainda que a pesquisa de fontes energéticas alternativas no estado de São Paulo estivesse em crescente desenvolvimento, possibilitando a aplicação da tecnologia de forma eficiente, havia a insistência do governo estadual e das concessionárias, que foram privatizadas pelo governo federal a partir de 1995, no uso excessivo de hidrelétricas para obtenção de energia.

Como contraponto a este fato - uso excessivo de fontes hidroelétricas -, teremos o último cenário relevante para as energias alternativas. Este se deu em nível nacional, com a criação de um programa que tinha como objetivo o incentivo para que as energias alternativas fossem inseridas na matriz nacional. Este programa também ficou no final, pois seu início se deu no fim do período recortado para a dissertação, e ainda estão ocorrendo suas proposições e resultados.

Em 2001 foi assinado pelo então Presidente Fernando Henrique Cardoso a Medida Provisória No. 14, que instituía a expansão da oferta de energia emergencial, e em 2002 criada a lei que define o Programa de Incentivo de Fontes Alternativas (PROINFA). O Proinfa estabelecia três fontes preferenciais para seu aumento na participação na geração de eletricidade no país: a eólica, as pequenas centrais hidrelétricas ( $\mathrm{PCHs})$ e a biomassa, deixando de fora outras fontes alternativas, tal como a energia solar. A legislação referente ao Proinfa definia que a geração excedente de energia proveniente das fontes alternativas consideradas acima deveria atingir no máximo 3.300 MW de potência instalada, sendo que os contratos para tal fornecimento

\footnotetext{
${ }^{112}$ Idem. p. 32.
} 
seriam diretamente ou por intermédio firmado pela própria Eletrobrás, com duração de até 15 anos. ${ }^{113}$

No quesito financiamento, ficou decidido que o BNDES inicialmente formularia um programa de apoio para a aquisição de energia elétrica dentro das perspectivas já referidas do Proinfa e também aquelas presentes do Programa Emergencial de Redução de Consumo de Energia Elétrica. A União foi autorizada a emitir títulos da dívida pública como garantia para operações nos contratos firmados com as empresas, além da presença da Caixa Econômica Federal como agente financeiro da operação. Portanto, houve uma espécie de reversão, pois as privatizações que ocorreram de 1993 a 1995 tinham como objetivo liquidar as dívidas interna e externa do país, financiadas pelo BNDES, porém, acabam sendo novamente postas em jogo no ano de 2001, tanto como garantia quanto como agente financiador das medidas tomadas para conter a crise energética brasileira, que foi causada pelo processo das privatizações. Qual seriam as direções do PROINFA?

O texto da lei de abril de 2002 agrega as medidas provisórias e as resoluções publicadas pelo Governo Federal sobre o racionamento, a taxação e o Proinfa. Em uma primeira etapa, do total de duas, aponta que o beneficiário dos investimentos seria o Programa Prioritário de Termoelétricas (PPT), dessa forma, indicando que a energia elétrica gerada seria baseada neste tipo de usina, privilegiando as matérias-primas que fossem direcionadas a esta como instrumento para suprir a crise nacional. Porém,

[...] a contratação [...] deverá ser distribuída igualmente, em termos de capacidade instalada, por cada uma das fontes participantes do programa e a aquisição da energia será feita pelo valor econômico correspondente à tecnologia especifica de cada fonte [...]. ${ }^{114}$

\footnotetext{
${ }^{113}$ Medida Provisória No. 14 de 21 de Dezembro de 2001.

${ }^{114}$ Lei No. 10.438, de 26 de Abril de 2002. p. 2.
} 
Inclusive, no critério de escolha dos geradores interessados em serem contratados no programa de incentivo teriam que apresentar as chamadas Licenças Ambientais de Instalação (LI) como requisito básico para a contratação. Outro elemento seria que na lei poderia ser admitido o Produtor Independente Autônomo, formato de atividade na qual se inserem as usinas sucro-alcooleiras que promovem a cogeração em suas instalações, e como benefício a estas, a primeira etapa das aquisições de energia seriam direcionadas a eles, desde que não estivessem associados a concessionárias de serviços públicos. ${ }^{115}$

Um programa energético que procurava incentivar a utilização da biomassa como matéria-prima para a cogeração. Além de que, indiretamente, agia sobre a energia solar, pois a tecnologia também se baseava no produtor autônomo, principalmente desde 1998, com os chamados Solar Home Systems. O documento indicava certo equilíbrio no destino dos recursos de outro mecanismo de incentivo às fontes preferenciais para o Governo Federal, a Conta de Desenvolvimento Energético (CDE). Esta conta procurava atribuir um valor igualitário às fontes energéticas, incluindo neste ponto o gás natural, prevendo que:

[...] nenhuma das fontes eólicas, biomassa, pequenas centrais hidrelétricas, gás natural e carvão mineral nacional, poderão ser destinados anualmente recursos cujo valor total ultrapasse a $30 \%$ (trinta por cento) do recolhimento do $\mathrm{CDE}[\ldots] .{ }^{116}$

Quanto aos objetivos da segunda etapa, previa-se que:

[...] atingida a meta de $3.300 \mathrm{MW}$, o desenvolvimento do Programa será realizado de forma que as fontes eólica, pequenas centrais hidrelétricas e biomassa atendam a $10 \%$ (dez por cento) do consumo anual de energia elétrica no País, objetivo a ser alcançado em até 20 (vinte) anos, aí incorporados o prazo e os resultados da primeira etapa. ${ }^{117}$

\footnotetext{
115 Idem. p. 4.

${ }^{116}$ Idem. p. 8.

${ }^{117}$ Idem. p. 3.
} 
O Proinfa poderia abrir novamente as portas da matriz energética nacional para as fontes alternativas, inserido as propostas já comentadas do relatório da Comissão Brasileira para a Rio +10 , de 2002, com a inclusão, a longo prazo, das fontes alternativas no parque gerador brasileiro. Neste sentido de abertura das fontes alternativas para a matriz energética, as conferências da ONU foram particularmente significativas ao possibilitarem o debate amplo e em várias instâncias sobre o tema, criando cenários para a atuação de cientistas que tinham como objeto de pesquisa as energias alternativas, tal como o PIPGE/USP. Além disso, serviram de influência no Brasil e no Estado de São Paulo para a discussão e análise das suas matrizes energéticas.

Por fim, define-se assim que a conjuntura que se apresentava proporcionaria novos elementos para o trabalho de grupos de pesquisa sobre energia. Tais elementos, a inclusão de novos atores e perspectivas de aplicação tecnologia, podem ser considerados como possibilidades para a atuação de grupos de pesquisa tal como o PIPGE, porém, qual foi a postura do PIPGE neste contexto? O Programa se adequou à nova realidade energética pela qual passava o país? Questiona-se, além disso, se este contexto de abertura para a pesquisa de energias alternativas, que foi criado em várias instâncias por meios internacionais, como as conferências e comissões governamentais, ou meios nacionais e estaduais, atinge ao PIPGE? A estrutura do Programa foi montada sobre uma base que permitisse a análise do objeto energia sob várias perspectivas? Como se caracteriza o discurso do Programa sobre energias alternativas? Estas questões direcionaram o próximo capítulo. 
"O que teria dito um de nossos ancestrais ao ver aqueles bulevares iluminados com um esplendor comparável ao do sol, aqueles milhares de carros circulando sem ruído sobre $o$ asfalto surdo das ruas, aquelas lojas ricas como palácios, de onde a luz se projetava em irradiações brancas [...]"

(Júlio Verne, 1863) 


\section{CAPÍTULO 2 - PRODUÇÃO, CRIAÇÃO E ARGUMENTAÇÃO: CONSTRUINDO ENUNCIADOS NO PIPGE.}

O primeiro capítulo trouxe a análise do processo histórico de formação de um conceito de energia no período contemporâneo, a formação das matrizes energéticas mundial e brasileira, a reestruturação por que este setor passou no Brasil, os problemas causados e as soluções encontradas, assim como, os eventos de caráter políticocientífico ocorridos entre os anos de 1970 e 2002, além de suas influências especificas para o Estado de São Paulo, que abriram cenários para a pesquisa em energias alternativas.

Estes eventos marcaram e caracterizaram o contexto histórico no qual a produção científica em energias alternativas se estabeleceu na década de 1990 e início dos anos 2000. Este capítulo tem como objetivo compreender essas pesquisas em um caso específico, o Programa Interunidades de Pós-Graduação em Energia da Universidade de São Paulo (PIPGE/USP) no período recortado.

Assim, inicio com a descrição institucional do PIPGE, destacando sua proposta interdisciplinar enquanto formadora de quadros profissionais para empresas e laboratórios de pesquisa em energia. Logo em seguida, faço a análise do discurso dos pesquisadores em energias alternativas do Programa, discurso este presente em sua produção literária, procurando demonstrar dessa forma as táticas que estes atores utilizavam para convencer de seus argumentos sejam os leitores especializados ou então a sociedade em geral. 


\section{O PIPGE: uma proposta interdisciplinar}

No Brasil, entre os anos 1970 e 2000, diversos grupos e programas científicos foram criados para $\mathrm{o}$ estudo de fontes energéticas. ${ }^{118} \mathrm{O}$ interesse aqui será especificamente por um programa de pesquisa criado com a iniciativa de aliar a questão tecnológica junto à de planejamento energético, unindo, portanto, duas áreas indissociáveis para o tipo de objeto que iriam pesquisar: o lado científico e o político $^{119}$, no caso, o Programa Interunidades de Pós-graduação em Energia da Universidade de São Paulo (PIPGE/USP).

Em 1998, no relatório enviado para a CAPES, constam informações estruturais e institucionais do Programa. Este relatório, composto quase dez anos depois do início das atividades do PIPGE, procura definir sua atuação dentro da área, abrangendo atividades de âmbito internacional, especialmente na América Latina, assim como, e mais incisivamente, dentro do Estado de São Paulo, seu principal espaço de influência.

O levantamento das fontes referentes ao estudo de caso a que me proponho se baseia em relatórios para a Capes, resoluções, teses, dissertações e artigos. Também foi realizada uma entrevista com o Professor Murilo Fagá, docente do Programa desde 1992. ${ }^{120}$ Tais fontes proporcionam vislumbrar elementos estruturais que me permitam caracterizar o Programa. Uma caracterização que busca estabelecê-lo enquanto um

\footnotetext{
${ }^{118}$ Somente no Estado de São Paulo, durante a década de 1990, o levantamento preliminar para o projeto desta pesquisa localizou aproximadamente 16 grupos científicos criados entre 1992 e 2002. E vale ressaltar que, num panorama nacional na década de 1970, temos o início das atividades da COPPE/UFRJ e, na década seguinte, do Grupo de Planejamento Energético da UNICAMP.

${ }^{119}$ Prof. Dr. Murilo Fagá, entrevista cedida em 25 de novembro de 2008.

${ }^{120}$ Não pode ser desconsiderado aqui o fato de que tais relatórios terem um objetivo e um direcionamento específico, ou seja, estão voltados para a agência governamental de fomento, portanto, seu teor contém um discurso que deve se enquadrar nas propostas e resoluções da agência. Nota-se, dessa forma, que os autores do relatório estabelecem um discurso sedutor, buscando convencer a agência da necessidade de suas atividades e pesquisa e a conseqüente continuidade no financiamento das mesmas. Ao mesmo tempo, utilizo estes relatórios, porque são reveladores das perspectivas que os autores, docentes do PIPGE, têm de suas atividades, pois apesar do sentido dado ao texto, não deixa de ser uma produção do Programa e de certa forma significativa das posições adotadas por seus pesquisadores.
} 
núcleo de pesquisas de amplo alcance, que atuava em diversos cenários e que ainda estava, durante os anos de 1992 a 2002, se consolidando como um centro formador que atraía pesquisadores e profissionais de várias localidades do Brasil e América Latina. O relatório justificava o Programa, afirmando que este:

[...] foi criado com o objetivo de formar profissionais de alto nível voltados às questões da energia; sua disponibilidade, seus usos, seus impactos e sua organização institucional. Neste contexto, o PIPGE propõe-se a formar estudantes de pós-graduação ao nível de mestrado, bem como oferecer cursos de extensão e serviços especializados à comunidade universitária e a atores externos à universidade, tais como, empresas, orgãos governamentais e não governamentais. ${ }^{121}$

Apresenta o objetivo de proporcionar uma formação ampla e voltada para as várias facetas que compõem o conceito de energia. Uma posição que se enquadra nas perspectivas da época, na qual a diversificação da formação do profissional em energia o permitiria atuar em áreas governamentais, industriais e científicas, estabelecendo também a possibilidade de trabalho nas companhias energéticas privatizadas desde o ano de 1995. Essa posição também teria permitido ao PIPGE se estabelecer durante a década de 1990 no cenário científico estadual e da América Latina como uma opção de pós-graduação para os interessados neste formato de ensino.

O PIPGE buscava trazer para seus quadros pesquisadores das engenharias, da física e da economia. Sua trajetória foi orientada no período por uma proposta de atuação que não ficasse marcada exclusivamente pelo desenvolvimento de tecnologias para o setor energético. Como afirmou em entrevista o Prof. Murilo Fagá, docente desde 1992, “não é um programa tecnológico", mas voltado para a análise e a crítica, o planejamento e a composição de profissionais para o setor energético, estatal ou

\footnotetext{
${ }^{121}$ CAPES. Relatório INTERUNIDADES EM ENERGIA / USP (NRD6) - 1998.
} 
privado. ${ }^{122}$ Encontrei esta relação entre as propostas do Programa e o setor de planejamento em outras documentações, tal como o relatório da CAPES de 1998

Tendo desenvolvido uma longa tradição de trabalho interdisciplinar, o PIPGE tem mantido estreitos laços de cooperação com outras unidades e outros programas da USP, bem como com outras instituições de pesquisa, nacionais e estrangeiras. O PIPGE mantém relações estreitas com as principais empresas energéticas brasileiras, sendo que muitos de seus estudantes do presente e do passado ocupam atualmente importantes postos de gerência nestas empresas. ${ }^{123}$

Criado abril de 1989, o PIPGE teve sua organização estruturada sobre uma base interdisciplinar, contando com a participação de quatro institutos da própria universidade: Instituto de Eletrotécnica e Energia (IEE), Escola Politécnica (EP), Faculdade de Economia e Administração (FEA) e o Instituto de Física (IF). Esta forma de organização denotava a intenção inicial do programa, pela constituição de um quadro de profissionais na área de energia oriundos de várias formações acadêmicas. Isto pode significar também a relação multidisciplinar que orienta as definições e também as decisões na área energética, tal como descrito nos objetivos propostos na primeira resolução do PIPGE:

[...] completar e aperfeiçoar a formação de diplomados em cursos de graduação e estimular a pesquisa e o ensino científico em geral e em particular na área interdisciplinar de Energia, englobando seus aspectos sociais, econômicos, tecnológicos, institucionais e ambientais. ${ }^{124}$

Podemos entender que a interdisciplinaridade, marcante na denominação e na própria definição dada ao PIPGE, proporcionaria a inclusão, no escopo teórico e prático da formação dos pesquisadores, de uma complexidade inerente tanto ao saber científico quanto ao próprio conceito de energia. Como veremos na análise da produção científica

\footnotetext{
${ }^{122}$ Prof. Dr. Murilo Fagá, entrevista cedida em 25 de novembro de 2008.

${ }^{123}$ CAPES. Relatório INTERUNIDADES EM ENERGIA / USP (NRD6) - 1998.

${ }^{124}$ Resolução PIPGE No. 3482, 1989, p.1.
} 
do grupo, seus pesquisadores adotam uma postura que permite a inclusão de outros campos do conhecimento sobre o objeto pesquisado: história, economia, e a físicasão exemplos destes olhares diversos nos trabalhos do grupo. Ao que condiciona a temática interdisciplinar, e não obstante inserida na complexidade, como uma metodologia de trabalho, e que, segundo Olga Pombo, traduz-se

[...] na constante emergência de novas disciplinas que não são mais do que a estabilização institucional e epistemológica de rotinas de cruzamento de disciplinas. Este fenômeno, não apenas torna mais articulado o conjunto dos diversos "ramos" do saber (depois de os ramos principais se terem constituído, as novas ciências, resultantes da sua subdivisão sucessiva, vêm ocupar espaços vazios), como o fazem dilatar, constituindo mesmo novos espaços de investigação, surpreendentes campos de visibilidade. ${ }^{125}$

Os cruzamentos entre disciplinas se caracterizariam como uma possibilidade prática, institucional, possibilitando ir além das indagações teóricas que seriam levantadas sobre pontos específicos de um determinado estudo. A interdisciplinaridade enquanto fenômeno da complexidade, como uma espécie de "fuga" ou "contraponto" aos trabalhos científicos encerrados sobre si mesmos, se processa, segundo afirma Olga Pombo, na:

[...] realização de diferentes tipos de experiências interdisciplinares de investigação (pura e aplicada) em universidades, laboratórios, departamentos técnicos; na experimentação e institucionalização de novos sistemas de organização, programas interdepartamentais, redes e grupos interuniversitários adequados às previsíveis tarefas e potencialidades da interdisciplinaridade; na criação de diversos tipos de institutos e centros de investigação interdisciplinar que, em alguns casos, se constituem mesmo como o pólo organizador de novas ciências, a sua única ou predominante base institucional. ${ }^{126}$

A prática interdisciplinar no PIPGE pode ser constatada também na variedade de propostas de pesquisas, nos temas dos trabalhos, além das disciplinas ofertadas durante

\footnotetext{
${ }^{125}$ POMBO, Olga. Práticas interdisciplinares. In: Sociologias [online]. no. 15, 2006. p. 210 (grifo do autor).

${ }^{126}$ POMBO, Olga. Op. cit. p. 225.
} 
o período de 1992 a 2002. No relatório de 1998, os dados referentes à produção de mestrado e doutorado do programa revelam a marca de 46 dissertações e 01 doutorado finalizados, isto dentro das linhas de pesquisa indicadas pelo programa para a realização da pós-graduação: 1) Análise Econômica Institucional de Sistemas Energéticos; 2) Energia, Meio Ambiente e Sociedade; 3) Fontes Renováveis e não Convencionais de Energia; 4) Planejamento Integrado de Recursos ${ }^{127}$; e atualmente contando com mais uma variável de investigação, 5) Redes Elétricas, Equipamentos e Qualidade de Energia. ${ }^{128}$ As 208 disciplinas ofertadas durante esses dez anos recortados têm ementas que abordam assuntos diversos, por exemplo: "energia e sociedade", "meio ambiente e a base de recursos naturais", "Energia, meio ambiente e desenvolvimento", "Gestão de serviços públicos de energia" e também, "Perturbações em redes elétricas", variando entre assuntos técnicos, sociais e políticos, além da economia. ${ }^{129}$

A divisão das linhas de pesquisa sobre a temática esboça também o sentido dado ao programa em seu início que, como afirmou o Professor Murilo Fagá, estaria preocupado com a "questão da oferta" de fontes energéticas nos cenários estadual e nacional, adequando-se às preocupações do contexto histórico. ${ }^{130}$ No relatório para a CAPES de 2005, consta que o programa cumpriu três etapas em seus objetivos. Uma primeira etapa teria sido concluída ao responder ao "choque do petróleo de 1970” e suas conseqüências para a década posterior. ${ }^{131}$ Entendemos, dessa maneira, que buscou a pesquisa de fontes que pudessem suprir a demanda em lugar do óleo combustível, e também fornecer o necessário planejamento energético para um estado como São Paulo, principal consumidor de energia do país. Já na segunda etapa, segundo o relatório:

\footnotetext{
127 CAPES. Relatório INTERUNIDADES EM ENERGIA / USP (NRD6) - 1998.

${ }^{128}$ CAPES. Relatório INTERUNIDADES EM ENERGIA / USP (NRD6) - 2005.

${ }^{129}$ Títulos das disciplinas e demais informações fornecidas pela secretaria do PIPGE.

${ }^{130}$ Prof. Dr. Murilo Fagá, entrevista cedida em 25 de novembro de 2008.

${ }^{131}$ CAPES. Relatório INTERUNIDADES EM ENERGIA / USP (NRD6) - 2005.
} 
[...] o Programa procurou adequar-se para dar resposta às questões ambientais da produção e uso da energia, em foco desde então. Caracterizando a cadeia da produção ao uso de energia como responsável por vários efeitos ambientais de alcance global (tal como o efeito estufa), de alcance regional (como chuvas ácidas) e de alcance local (como a deterioração da qualidade do ar em regiões urbanas), novamente o uso racional e eficiente da energia destacou-se como uma das formas mais efetivas para enfrentar-se tais questionamentos. Portanto, reiterava-se a relevância desse tópico dentro do Programa. Estudava-se, também, a inserção das energias renováveis no contexto energético do país como alternativa viável para responder às preocupações ambientais. ${ }^{132}$

O PIPGE, nesta fase, procurou a inclusão de uma preocupação ambiental em suas discussões. O relatório não determina o momento em que ocorrem as etapas; podemos inferir, entretanto, que a segunda etapa tenha sido iniciada a partir de 1992 , junto às preocupações ambientais surgidas no contexto da ECO-92, quando o uso de energias "limpas" se generaliza, tornando-se parte de políticas governamentais, inclusive no Brasil e Estado de São Paulo. A terceira fase apresenta análises sobre questões políticas e regulatórias, tendo em vista a mudança no panorama da geração e distribuição de energia que se processava no país com a privatização das companhias energéticas, inclusive no Estado de São Paulo a partir de 1995, e também as alterações no mercado energético internacional, especificamente na América Latina.

[...] Passa-se a discutir temas como: a eficiência dos mercados; o papel da competição no setor energético; a privatização e o papel do Estado no setor; Agências reguladoras de energia; a regulação e o planejamento energético. Com o despontar de novos cenários de incerteza no suprimento de energia para o país, enfatiza-se, uma vez mais, o papel do uso racional da energia e das energias alternativas como instrumentos a serem implementados, mostrando-se sua coerência com os diferentes processos de reestruturação da indústria energética. Por outro lado, com a disponibilidade de grandes quantidades de gás natural, principalmente para o Estado de São Paulo, após a construção do maior gasoduto internacional do Hemisfério Sul, o gasoduto Bolívia-Brasil, o Programa passou a dedicar particular interesse às discussões relativas ao gás natural, seus problemas contratuais e estratégias mais racionais de uso, bem como

${ }^{132}$ CAPES. Relatório INTERUNIDADES EM ENERGIA / USP (NRD6) - 2005. p. 3. 
se reavivou o debate da integração regional energética na América do Sul. ${ }^{133}$

Aparentemente torna-se um Programa de planejamento, gestão e de formulação de políticas públicas. Formador de profissionais para o setor, o que ainda assim adequava a terceira etapa às anteriores, pois procurava substitutos ao petróleo e também mantinha o enfoque ambiental nas suas preocupações. Um exemplo desse novo enfoque e a adaptação ao contexto que se apresentava pode estar nas teses e dissertações do Programa produzidos a partir de 1992. No ano de 2002, foram 98 Mestrados e 15 Doutorados defendidos no PIPGE. Há desde trabalhos com análises tecnológicas de sistemas energéticos, tal como "A utilização do ônibus a gás natural comprimido na frota de ônibus urbano como alternativa para o redução da poluição atmosférica na região metropolitano de S.P.”, uma dissertação de mestrado do ano de $1996^{134}$, até temas voltados para o planejamento energético, como um de 1993, “A integração energética da América Latina iniciando pelos países do cone Sul: o caso Argentina -

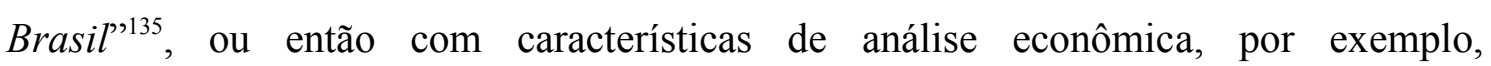
“Externalidades na produção de álcool combustivel no estado de São Paulo", também de $1996 .^{136}$

$\mathrm{Na}$ perspectiva de crítica ao quadro energético no Brasil e no Estado de São Paulo, o programa conta também com um laboratório e um centro de referência, ambos específicos para a área de "fontes renováveis e não-convencionais". O Laboratório de Sistemas Fotovoltaicos (LSF) opera na pesquisa de sistemas fotovoltaicos, sua aplicação

\footnotetext{
${ }^{133}$ CAPES. Relatório INTERUNIDADES EM ENERGIA / USP (NRD6) - 2005. p. 3.

${ }^{134}$ MACHADO, Fernando T. H. F. A utilização do ônibus a gás natural comprimido na frota de ônibus urbanos como alternativa para o redução da poluição atmosférica na região metropolitano de S.P. São Paulo: PIPGE (Dissertação de Mestrado), 1996.

${ }^{135}$ PAULA, Ericson de. A integração energética da América Latina iniciando pelos países do cone Sul: o caso Argentina - Brasil. São Paulo: PIPGE (Dissertação de Mestrado), 1993.

${ }^{136}$ BOLIGNINI, MARLY FRÉ. Externalidades na produção de álcool combustível no estado de São Paulo. São Paulo: PIPGE (Dissertação de Mestrado), 1996.
} 
e também, na capacitação dos pesquisadores envolvidos no laboratório. Dr. Roberto Zilles, professor do PIPGE, informa que:

[...] O laboratório e seu grupo de pesquisadores são capazes de: caracterizar componentes; cooperar com a indústria no desenvolvimento de equipamentos; realizar estudos de competitividade econômica para distintas opções energéticas; estabelecer mecanismos de implantação e monitoramento de sistemas autônomos e promover cursos de treinamento e especialização. ${ }^{137}$

Isso caracterizaria as atividades deste laboratório como basicamente de proposição e análise de tecnologias, além da interação do Programa com o mercado de trabalho e as indústrias do setor energético, possibilitando também, aos seus pesquisadores, o trato com as questões econômicas envolvidas na área de energia e a prática fora do laboratório, pelo acompanhamento da utilização dos equipamentos fotovoltaicos nas redes instaladas. ${ }^{138}$

Desde 1996, o PIPGE abriga o Centro Nacional de Referência em Biomassa (CENBIO). Esse espaço, cuja "finalidade de promover o uso da biomassa como fonte renovável e eficiente de energia, em substituição aos combustiveis fósseis", foi criado pelo Ministério da Ciência e Tecnologia, Secretaria de Energia do Estado de São Paulo e a Universidade de São Paulo. O centro conta ainda com a participação de outras entidades ligadas ao tema energia ou então à biomassa, espalhando suas redes de atuação inclusive para outros países. ${ }^{139}$ Foi premiado em 1998 pela Environmental

\footnotetext{
${ }^{137}$ ZILLES, Roberto. Atividades de pesquisa em energia solar fotovoltaica no IEE/USP. In: CRESESB Informe. ano V, n. 6, setembro, 2000. p.10.

${ }^{138} \mathrm{Idem}$.

${ }^{139}$ Tais instituições, ONGs, órgãos governamentais constam no relatório, são elas: “[...] Biomass Users Network/Brasil, [...] ANELL, a Agência Nacional de Energia Elétrica e da FINEP. [...] Ministério da Indústria, Comércio e Turismo, Secretaria de Assuntos Estratégicos, ANP, IBAMA, Coopersucar, União da Indústria Canavieira, DATGRO, AABRACAVE, ORPLANA, Klabin do Paraná, Companhia Energética Santa Elisa. [...] Unicamp, EFEI/Itajubá, Universidade Federal do Paraná, Universidade de Santa Maria, Instituto de Pesquisa da Amazônia (INPA), COPPE, IPT, ISM, Universidade de Viçosa, Universidade Federal de Sergipe, Universidade Estadual de Pernambuco, CIENTEC [...] National Renewable Energy Laboratory, National Biodiesel Foundation, Princeton University, UNESCO, CIRAD (França, GREENTIE (International Energy Agency). O CENBIO tornou-se oficialmente no ano de $98 \mathrm{em}$
} 
Protection Agency dos EUA, com o Climate Protection Award, prêmio dado pela contribuição ao clima. ${ }^{140}$

A presença do laboratório LSF e do CENBIO pode servir também para compreender o direcionamento do programa para as fontes de energias inseridas na linha de pesquisa em questão. Como fontes renováveis e alternativas de energia, o PIPGE, até o ano de 2002, privilegiou principalmente a biomassa de cana de açúcar, a energia solar fotovoltaica e o gás natural. Porém, as fontes energéticas que constam como alternativas e renováveis é apenas a biomassa e a solar, não sendo arrolado o gás natural. Caracterizarei, a partir dos textos dos pesquisadores e das bibliografias sobre o tema, tais fontes renováveis estudadas pelo PIPGE.

O uso da nomenclatura "energia solar" é uma denominação ampla, pois esta se divide em diversas aplicações. De modo geral, a energia solar tem como base teórica a conversão da radiação eletromagnética emanada pelo sol para formas que o homem possa utilizar em seu cotidiano. ${ }^{141}$ A utilização do sistema fotovoltaico é a tecnologia mais difundida atualmente, sendo um produto que não tem sua produção restrita a institutos de pesquisa, mas é comercializado por indústrias privadas em todo o mundo. No Brasil pode ser encontrado em residências na zona urbana e também na zona rural. Os componentes de um sistema fotovoltaico são: Módulo fotovoltaico; Controlador de carga; Sistema de armazenamento de energia; Inversor de corrente contínua em corrente alternada. ${ }^{142}$ Os principais processos de aproveitamento da energia solar são: térmico, elétrico e químico. $\mathrm{O}$ processo térmico em altas temperaturas $\left(-1000^{\circ} \mathrm{C}\right)$ consiste na

GLO - Greentie Liaison Office, atuando como representante único no Brasil do Greenhouse Gases Technologie Information Exchange - GREENTIE, organização holandesa ligada à INTERNATIONAL ENERGY AGENCY - IEA.” (Cf. CAPES. Relatório INTERUNIDADES EM ENERGIA / USP (NRD6) 1998. p. 8).

${ }^{140}$ CAPES. Relatório INTERUNIDADES EM ENERGIA / USP (NRD6) - 1998. p. 8.

${ }^{141}$ ALDABÓ, Ricardo. Energia solar. São Paulo: Artliber Editora, 2002.

${ }^{142}$ SERPA, Paulo Marcos Noronha. Eletrificação fotovoltaica em comunidades caiçaras e seus impactos socioculturais. São Paulo: PIPGE, (Tese de Doutorado), 2001. 
utilização de uma espécie de forno solar parabólico, sendo empregado em geradores de vapor d'água, fornos solares e na transformação de energia elétrica em mecânica. Já o processo térmico de baixa temperatura $\left(-100^{\circ} \mathrm{C}\right)$ é aproveitado no aquecimento de ambientes, condicionamentos de ar, refrigeração, evaporação, destilador e etc. ${ }^{143}$

A "biomassa" talvez seja uma das formas mais antigas de obtenção de energia. Consiste na utilização de matéria orgânica, seja ela cultivada ou recolhida na natureza, para aplicação em vários processos. Lenha, cana-de-açúcar e outros derivados da agricultura são matérias-prima da biomassa, sendo que sua utilização pelo ser humano remonta a séculos de atividades como: cocção, aquecimento das casas e demais práticas que necessitavam do fogo. ${ }^{144}$ No PIPGE, a aplicação da biomassa de cana-de-açúcar nas pesquisas se caracteriza pela chamada "cogeração". A cogeração se baseia na obtenção de energia térmica e energia mecânica por uma mesma fonte energética, no caso a biomassa. Lembrando que a energia elétrica é obtida a partir da conversão de outras formas de energia, na cogeração ela se origina da energia mecânica ao passar pelo gerador de eletricidade. ${ }^{145}$ A tecnologia utilizada para este processo são turbinas movidas pelo vapor superaquecido originado na queima da biomassa (bagaço, palha e o vinhoto), que produz ao mesmo tempo as duas formas de energia da cogeração, térmica e mecânica. ${ }^{146}$

De forma geral, o PIPGE, ao ser constituído por quatro áreas que podem compor o quadro das decisões estratégicas no planejamento institucional de um governo ou empresa privada, privilegiou a formação de uma tecnocracia especializada na tomada de

\footnotetext{
${ }^{143}$ ALDABÓ, Op. cit. 2002; HALACY, Daniel S. La nueva era de la energia solar. Buenos Aires: Argentina: Marymar Ediciones, 1975.

${ }^{144}$ GOLDEMBERG, José \& VILLANUEVA, Luz D. Energia, meio ambiente e desenvolvimento. São Paulo: EDUSP, 2003.

${ }^{145}$ COELHO, Suani Teixeira. Mecanismos para implementação da cogeração de eletricidade a partir de biomassa: um modelo para o Estado de São Paulo. São Paulo: PIPGE (Tese de Doutorado), 1999.

${ }_{146}$ PELLEGRINI, Maria Cristina. Inserção de centrais cogeradoras a bagaço de cana no parque energético do Estado de São Paulo: exemplo de aplicação de metodologia para análise dos aspectos locacionais e de integração energética. São Paulo: PIPGE (Dissertação de Mestrado), 2002.
} 
decisões e na montagem de planos de médio e longo prazos referentes à matriz energética, seja qual for sua instância. E ainda, representando um direcionamento já presente no contexto brasileiro de formação de instituições de análise e propostas energéticas, tal como a COPPE na UFRJ durante a década de 1970 e o Programa de Planejamento Energético da UNICAMP nos anos 1980.

Qualificando seus quadros em formação, o PIPGE proporcionaria uma espécie de interdisciplinaridade, funcionado como um incremento nos currículos dos pesquisadores formados, podendo ou não exercer uma função nas atividades profissionais destes. Para o Prof. Fagá, em entrevista, a questão da interdisciplinaridade teria deixado de ser uma base do programa entre os anos de 91/92, quando o Instituto de Eletrotécnica e Energia assume as funções administrativas do mesmo, inclusive a contratação dos docentes para suprir as cadeiras das disciplinas ministradas. ${ }^{147}$ Mas isto não significou que deixaram de utilizar o termo nos relatórios para a agência governamental, tal como exposto acima.

Talvez a análise da literatura do Programa possa proporcionar o vislumbre sobre a condição ou não interdisciplinar adotada, como base nas análises sobre o tema energia, especialmente as fontes alternativas. No próximo item, a problematização será em torno da análise do discurso científico do PIPGE, buscando demonstrar as maneiras como se caracteriza o trabalho realizado na área de energias alternativas durante o período em questão.

\section{Discurso Científico no PIPGE: autores, leitores, direções, tecnologia e política.}

\footnotetext{
${ }^{147}$ Prof. Dr. Murilo Fagá, entrevista cedida em 25 de novembro de 2008.
} 
A produção literária do Programa Interunidades de pós-graduação em Energia (PIPGE/USP) durante os anos de 1992 a 2002 foi marcada pela presença de teses e dissertações, artigos para periódicos e revistas, além dos textos para eventos, tanto nacionais quanto internacionais. ${ }^{148}$ Esta literatura apresenta-se enquanto uma oportunidade para se compreender que tipos de argumentos os pesquisadores utilizaram no Programa, além da possibilidade em vislumbrar as atividades de pesquisa que preconizavam como um grupo de pesquisadores, dentro da temática: energias renováveis e não-convencionais.

Tendo como base as fontes documentais utilizadas, artigos, teses, dissertações, entendo que o PIPGE apresenta em sua produção científica dois tipos de trabalhos que evidenciam as suas diretrizes e encaminhamentos na construção de um enunciado. Ambas as vertentes são definidas na medida em que focam grupos específicos de leitores. Além disso, podemos dividir esta produção em duas fases, a primeira de 1992 a 1996 e a segunda de 1997 a 2002, que se caracterizaram por permanências e mudanças nas argumentações utilizadas nos textos. De forma geral, as fontes abordam quatro fatores principais em relação às fontes alternativas de energias pesquisadas: cientificidade, meio ambiente, economia e política.

Do primeiro tipo são as teses e dissertações defendidas no Programa que apresentam enquanto uma de suas características o direcionamento a outros pesquisadores que atuam na área de energia, assim como ao Governo do Estado de São Paulo, especialmente o setor energético, aos seus técnicos e à burocracia que compunha os quadros das concessionárias de energia do estado. Em relação ao teor dos trabalhos nessa vertente, os pesquisadores adotam uma postura que se preocupava em contemplar as quatro áreas que formavam o Programa; os atores apresentam, portanto, as

\footnotetext{
${ }^{148}$ Conferir a relação completa das fontes no final da dissertação.
} 
características e as vantagens de cada tecnologia, trazendo dados, equações, hipóteses, variáveis, questões de economia e, por vezes, estudos de casos cujos exemplos ocorreram fora do país.

Já o segundo tipo são os artigos e textos sobre as pesquisas, sejam eles publicados em anais de eventos, em periódicos, jornais ou revistas. O teor dessa literatura se volta para um público geral, não importando se são ou não conhecedores do tema. Tiveram, inclusive, como objetivo principal, além de divulgar os trabalhos, discutir as barreiras para a aplicação da tecnologia no cenário estadual ou nacional. Seu conteúdo, na maioria dos casos, pode ser considerado "mais leve", ou seja, contemplando pontos específicos das pesquisas, sem adentrar nas questões técnicas, se preocupando com sua contextualização, seus resultados, propostas de aplicação e críticas a política e à matriz energética nacional e no Estado de São Paulo.

Numa constatação inicial, percebi que houve o direcionamento das fontes que apresentavam propostas para um público-alvo específico: as companhias energéticas, estatais ou privatizadas e a burocracia estatal. A isto se soma que muitos artigos têm o mesmo teor, sendo utilizados em vários eventos, constando o mesmo discurso enquanto argumentos e conclusões, embora, como veremos, tenha havido mudanças de enfoque durante o período. $\mathrm{O}$ que, como será analisado em seguida, também indica uma característica do programa científico em foco.

A partir dessas verificações iniciais sobre os tipos do discurso da literatura científica do PIPGE, a análise aborda quatro características dessa produção. Estas características são encontradas de maneira geral nas fontes documentais aqui utilizadas, especialmente na linha de pesquisa sobre energias renováveis e não convencionais. Inicialmente procuro a hierarquização da produção de textos, mostrando as autorias em relação à posição do autor, aluno ou professor, dentro do Programa. O segundo item 
explora o foco dos textos, destacando para que tipo de leitores são direcionados os textos. O terceiro e o quarto item são relativos ao discurso sobre as tecnologias com que os pesquisadores trabalham, sendo que o terceiro busca os encaminhamentos, larga e baixa escala, pretendidos pelos autores para a utilização do equipamento e o quarto item tem como mote analisar o olhar do pesquisador, destacando os argumentos e as críticas, quando e se existirem, sobre seu objeto.

1) Autores e autorias: estabelecendo hierarquias cientificas no PIPGE

Uma característica marcante a ser encontrada na produção cientifica do Programa é a quantidade de autores para um mesmo trabalho. Como formador de pesquisadores e profissionais para o setor energético, o PIPGE apresenta grande quantidade de textos acadêmicos. A opção por este tipo de autoria, em conjunto, se explica pela perspectiva do PIPGE enquanto grupo científico que assumiria, portanto, as características deste formato de atividade dentro da comunidade científica. Como definiu Latour e Woolgar, nos anos 1970:

No que se refere à produção de fatos, pode-se dizer que um grupo é formado pela convergência de múltiplas trajetórias. Sua organização pode ser interpretada como a acumulação dos movimentos e dos investimentos de seus membros. A conjunção das trajetórias dos atores constitui uma hierarquia de posições administrativas quase perfeitas [...]. ${ }^{149}$

Publicar em grupo demonstra a hierarquia seguida dentro dos "espaços" de ciência. O cientista cujo renome se destaca em meio aos companheiros de laboratório ${ }^{150}$

\footnotetext{
${ }^{149}$ LATOUR, Bruno \& WOOLGAR, Steve. A vida de laboratório: a produção dos fatos científicos. Rio de Janeiro: Relume Dumará, 1997. p. 244.

${ }^{150}$ Importante ressaltar que utilizo o termo "laboratório" como alegoria para espaço acadêmico ou científico de análise, compreensão e produção de dados sobre determinado objeto, não indicando desta forma, um local de atividades estritamente de alguns tipos de ciências.
} 
deverá ser colocado, invariavelmente, em primeiro no rol dos autores de determinada literatura.

No PIPGE houve no período recortado a presença marcante dos docentes na produção do mesmo; por exemplo, em 1998, no já referido relatório para a CAPES, o Professor José Goldemberg estava relacionado com 40 publicações de um total de 70 para todo o Programa. ${ }^{151}$ Enquanto isso, 15 foram os textos nos quais houve a participação dos discentes, todos em anais de eventos.

Outra forma de se caracterizar a hierarquia é a avaliação que se faz das pessoas, considerando-as substituíveis ou não. Uma informação é mais valiosa quando é original. Isso quer dizer que os que ocupam uma posição mais elevada na hierarquia são os mais dificilmente substituíveis [...]. ${ }^{152}$

Podemos entender que aqueles que são "passageiros" no Programa, ou seja, os alunos, terão a missão de produzir e ir embora, acompanhando os rumos dados pelo topo da hierarquia, os docentes. Evidentemente que a publicação com vários autores garante o prestígio necessário para aqueles que ainda não são reconhecidos no meio acadêmico. ${ }^{153}$ A média de autores que assinam os artigos do PIPGE na área de energias alternativas varia de dois a oito pesquisadores, sendo sua maioria discentes, abrindo as portas dos periódicos importantes, permitindo ao Programa ampliar suas redes e seu conceito, ao mesmo tempo em que incrementa o curriculum dos pesquisadores "passageiros".

Neste quesito, deve ser feita uma ressalva, talvez caso único dentro do PIPGE, que foi participação da pesquisadora, aluna de pós-graduação mestrado (1992) e depois doutorado (1999), Suani Teixeira Coelho, cuja produção textual foi significativa,

\footnotetext{
${ }^{151}$ CAPES. Relatório INTERUNIDADES EM ENERGIA / USP (NRD6) - 1998. (Produção Bibliográfica). ${ }^{152}$ LATOUR \& WOOLGAR. Op. cit. 1997. p. 253.

${ }^{153}$ LATOUR \& WOOLGAR. Op. cit. 1997.
} 
ultrapassando muitas vezes alguns docentes em quantidade de publicações. ${ }^{154}$ Porém, a pesquisadora, atualmente professora do Programa, não se destacou dos demais alunos pela iniciativa de publicações enquanto única autora, podendo ser considerada como exemplo de autoria em grupo, já que grande parte de suas publicações tenham dois ou mais autores junto a ela, e normalmente um docente. Isso indica que, mesmo participativa no conjunto da produção literária do Programa, ficaria ainda marcada por sua posição na hierarquia enquanto discente, ou seja, dentro da perspectiva de publicações seguindo as orientações dos docentes do PIPGE.

Assim, entra em cena a questão da credibilidade, uns partindo em busca de melhorar sua imagem enquanto cientista e outros fazendo uso dela para abrir caminhos e trazer financiamento para sua pesquisa, inserindo-se na lógica do prestígio e na dinâmica da produção dos fatos. Há muitas vantagens em se destacarem em meio à comunidade científica, assim como, e quase invariavelmente, sendo levados a um reconhecimento "externo" pelos governantes e talvez até mesmo pela sociedade em geral. Prêmios, títulos, publicações são exemplos de méritos acadêmicos que podem ser alcançados; soma-se a isso a recompensa financeira. Em 2008, por exemplo, o Professor Goldemberg, maior produtor do PIPGE, foi premiado por uma instituição japonesa, pelo conjunto da obra, e agraciado com uma quantia em dinheiro. ${ }^{155}$

A tática de escrever junto a vários colaboradores pode ser utilizada diretamente para fortalecer o argumento discutido no texto. No jogo do convencer da literatura acadêmica, a necessidade de aliados que possam corroborar com o enunciado, seja como referência bibliográfica ou então como co-autores, auxiliaria no equilíbrio de

\footnotetext{
${ }^{154}$ Como poderão perceber, seus trabalhos aparecem em diversos momentos deste capítulo e do próximo. ${ }^{155}$ Segundo a notícia: "O físico José Goldemberg, 80, professor da Universidade de São Paulo, é o novo quase-milionário da ciência brasileira. Goldemberg ganhou ontem de uma fundação japonesa um prêmio de 50 milhões de ienes (cerca de R $\$ 800$ mil) por 'ter dado grandes contribuições na formulação e implementação de diversas políticas associadas a melhoras no uso e na conservação de energia"'. (Folha Online. Físico da USP ganha prêmio de R\$ 800 mil. Acessado em 20/06/2008. www.folhaonline.com.br).
} 
forças junto aos opositores, pois: “[...] Um documento se torna científico quando tem a pretensão a deixar de ser algo isolado e quando as pessoas engajadas na sua publicação são numerosas e estão explicitamente indicadas no texto [...]". ${ }^{156}$ Dentro dessa lógica de Latour, ao sair do isolamento o texto angaria referências e junto a elas a força necessária para interessar as pessoas e convencê-las do enunciado. A coletividade é necessária para as ciências; o autor sozinho não tem condições de mobilizar o mundo com seu enunciado sem que a sociedade lhe apóie. O convencer se torna base para compreender qualquer tipo de literatura das ciências, servindo de chave para entrar nos laboratórios e nas tessituras que envolvem a construção científica de um fato.

Por fim, este comportamento aparentemente serviu para divulgar o Programa nos diversos cenários em que pretendia atuar: estadual, nacional e internacional. A utilização de vários autores incrementaria sua produção, melhorando seu desempenho nos avaliadores de qualidade dentro do país, assim como trazendo pesquisadores e parcerias com universidades internacionais para seus quadros. O grupo se fortalece, indicando também a representatividade política do grupo. Neste sentido, devemos lembrar que dois docentes foram encarregados pelo Estado de São Paulo para a pasta de energia. $^{157}$

\section{2) Em busca dos leitores e de informações}

Os textos produzidos permitem aos pesquisadores do PIPGE sair dos "laboratórios", numa espécie de translação que os leva diretamente ao público. Neste movimento, embora aparente, como apontou Latour acima, os autores se expõem, mas

\footnotetext{
${ }^{156}$ LATOUR, Bruno. Ciência em ação: como seguir cientistas e engenheiros sociedade afora. São Paulo: Editora UNESP, 2000. p. 58

${ }^{157}$ José Goldemberg foi diretor das companhias energéticas do Estado de São Paulo durante o Governo de Franco Montoro de 1983 a 1986 e David Zylbersztajn entre 1995 e 1998 no governo de Mário Covas.
} 
isso não significa um enfraquecimento de seu discurso. Para Latour, sair do espaço de trabalho permite ao pesquisador guarnecer seu discurso, principalmente se o ato de convencer for efetivo, ou seja, acaba por transformar o lado de fora em um único laboratório.

\begin{abstract}
A única maneira para um cientista reter a força conquistada dentro de seu laboratório pelo processo que eu descrevi não é ir para fora onde ele pode perdê-la toda. Isto é novamente muito simples. A solução é nunca sair. Isto significa que eles estão presos nos vários lugares onde fazem seus trabalhos? Não. Significa que eles irão fazer todo o possível para estender algumas configurações das condições que tornam possível a reprodução favorável das praticas laboratoriais [...] Se isto significa transformar a sociedade em um imenso laboratório, eles o farão [...]. ${ }^{158}$
\end{abstract}

Quando o cientista sai de seu laboratório, apenas mudaria de instância, ou seja, entraria em um laboratório maior que o anterior, onde as condições de prática científica ainda seriam controladas por suas teorias e métodos. Este tipo de translação somente ocorre de forma definida entre os atores do PIPGE no segundo momento da literatura, com início a partir de 1998. Quando se dá a consolidação do doutorado no Programa, e dentro da linha de pesquisas fontes renováveis e não-convencionais, a literatura é marcada pelos trabalhos de campo dos pesquisadores. Segundo a documentação, posso compreender que a saída dos laboratórios permite que conheçam os destinos dados às tecnologias que pesquisam; além disso, inaugura também a presença da preocupação social e ambiental, que se consolida no argumento dos cientistas.

Essas translações, mudanças e ampliações do foco e espaço de análise são características que proporcionam ao cientista divulgar suas pesquisas, ao mesmo tempo

\footnotetext{
158 "The only way for a scientist to retain the strength gained inside his laboratory by the process I have described is not to go outside where he would lose it at once. It is again very simple. The solution is in never going out. Does that mean that they are stuck in the few places where they work? No. It means that they will do everything they can to extend to setting some of the conditions that make possible the reproduction of favorable laboratory practices [...] If this means transforming society into a vast laboratory, then do it [...]." LATOUR, Bruno. Give me a laboratory and I will raise the world. In: KNORR-CETINA, Karin e MULKAY, Michael. Science observed: perspectives on the social study of science. London: Sage Publications, s/d. p. 166 (Grifo do Autor).
} 
em que busca convencer seu público dos enunciados. No PIPGE, o discurso foi se adaptando ao contexto, sendo uma ferramenta fundamental para o desenvolvimento dos textos. Pois, um programa que se propõe a formular políticas energéticas e aplicar tecnologias e que atuava junto aos organismos que direcionam o setor energético, conseqüentemente deve adaptar seu argumento aos interesses destes, ou então, na direção contrária, atuando na crítica as decisões geradas por esses órgãos, ou seja, a junção entre discurso e contexto no PIPGE, tem a função de posicionar os pesquisadores junto ao setor energético do Estado de São Paulo ou então buscando elementos de crítica a este.

Dessa forma, a literatura científica exerce uma função fundamental para que as estratégias dos cientistas tenham o efeito de passar pelas controvérsias que possam surgir. Este "espaço" terá o papel de auxiliar o cientista a convencer sobre seus enunciados, fortalecendo seu ponto de vista.

Compreendo que, para convencer alguém, o autor deve saber para quem direcionar o discurso, e quais seriam os interesses deste.

Em uma dissertação intitulada "Avaliação do uso da vinhaça da cana-de-açúcar na geração de energia elétrica (Estudo de Caso)" de 1994, o pesquisador Reinaldo Almança, ao abordar a possibilidade de utilização da vinhaça da cana, líquido proveniente da moagem da matéria-prima, em processos de cogeração nas usinas, direciona seu texto para o setor sucro-alcooleiro e também para as companhias energéticas do Estado de São Paulo. Procurando unir os interesses de ambos para a geração de eletricidade, ressalta ainda o aspecto social da empreitada:

[...] procurou-se avaliar a possibilidade de geração elétrica a partir do aproveitamento da vinhaça da cana-de-açúcar e, por similaridade, a possibilidade do setor sucro-alcooleiro vir a contribuir, sob a forma de 
parceria com o setor público, na oferta de energia elétrica à rede, lapidando ainda mais sua imagem junto a sociedade. ${ }^{159}$

O autor enquadra nas páginas iniciais da sua dissertação os dois leitores que procura convencer sobre aquilo que enuncia em relação a seu objeto. Isso porque ainda em 1994 o controle da geração e distribuição de eletricidade se encontrava sob a administração pública. Portanto, cabia escrever sobre a possibilidade de uma parceria entre ambos, principalmente quando um ano antes, em 1993, já tinham firmado um acordo neste sentido, enquanto um Protocolo para a venda dos excedentes da geração de eletricidade nas usinas.

Tal documento, "Programa para cogeração e auto-produção de eletricidade no setor açúcar/álcool do Estado de São Paulo", segundo os pesquisadores do PIPGE David Zylbersztajn e Suani Coelho, ao se referirem ao protocolo em 1996, afirmam que este estabelecia: “[...] o preço de compra da eletricidade suprida deverá ser igual ao seu custo marginal [...]." ${ }^{\text {160 }}$ Com o Protocolo em aberto, questionava-se o seu real funcionamento, já que poucas usinas do Estado de São Paulo, nove em 1992 e mais duas entrariam em funcionamento no mesmo ano, realizavam a cogeração e a venda dos excedentes "[...] num total de 30 milhões de KWh/ano na safra, suficientes para abastecer uma cidade de 200.000 habitantes por um mês [...]”, o que demonstrava, mesmo assim, para a pesquisadora Suani Coelho que "[...] o caminho é viável.",161 Entretanto, devido aos baixos preços pagos pela eletricidade gerada, ocorreu o desinteresse dos usineiros em investir nas plantas de cogeração, levando a mesma

\footnotetext{
${ }^{159}$ ALMANÇA, Reinaldo Alves. Avaliação do uso da vinhaça da cana-de-açúcar na geração de energia elétrica (Estudo de Caso). São Paulo: PIPGE, (Dissertação de Mestrado), 1994. p. 4.

160 "[...] the purchase price of electricity surplus should be equal to the marginal cost [...]." ZYLBERSTAJN, David e COELHO, Suani Teixeira. A preliminary analysis of mechanisms to improve biomass-origin co-generation in Brazil. In: $9^{\text {th }}$ European Bioenergy Conference. Copenhagen/Dinamarca: Elsevier Science Ltd. Junho, 1996. p. 450.

${ }^{161}$ COELHO, Suani Teixeira. Avaliação da cogeração de eletricidade a partir de bagaço de cana em sistema de gaseificados e turbina a gás. São Paulo: PIPGE (Dissertação de Mestrado), 1992. p. 21.
} 
pesquisadora Suani Coelho revelar em 1996 que: “[...] e muitas industrias não estão interessadas em vender eletricidade por causa dos preços baixos oferecidos pelas companhias." 162

O foco estava direcionado aos usineiros e às Companhias Energéticas Estaduais, em franco processo de privatização, pois mediante a interação com estes atores seria possível a formulação de políticas públicas que atendessem a principal argumentação dos pesquisadores, a inserção da tecnologia de cogeração da cana, tal como aconteceu no caso do Protocolo de 1993. Os casos como o do pesquisador Reinaldo Almança e de Suani Coelho se repetem ao longo da produção textual do PIPGE no período que vai até 2002. O mesmo tipo de argumentação encontrei em outros autores. Na dissertação de Sergio Oliveira de 1997, "Dimensionamento de sistemas fotovoltaicos autônomos: ênfase na eletrificação de residências de baixo consumo", podemos encontrar o discurso direcionado ao Estado:

Toda a tecnologia nova e emergente necessita de um conjunto de normas e recomendações que direcione, da forma mais simples e objetiva possível, a sua utilização. A tecnologia fotovoltaica não foge a esta regra e, atualmente, com um aumento na sua inserção no contexto energético brasileiro, surge a necessidade da criação de uma normatização própria, que leve em consideração suas características específicas. ${ }^{163}$

A ênfase do autor fica a cargo da implantação da tecnologia fotovoltaica num cenário carente de abertura a formas energéticas alternativas, principalmente em São Paulo, cuja matriz principal era a geração hidrelétrica.

Após 1995, com a entrada de um novo elemento, as empresas privadas, e junto a estas, o mercado de energia, teremos o foco das teses e dissertações se voltando para

\footnotetext{
162 "[...] and so most industries are not interested on selling electricity due to low price offered by utilities." ZYLBERSTAJN, David e COELHO, Suani Teixeira. Op. cit. 1996. p. 450.

${ }^{163}$ OLIVEIRA, Sérgio Henrique Ferreira de. Dimensionamento de sistemas fotovoltaicos autônomos: ênfase na eletrificação de residências de baixo consumo. São Paulo: PIPGE (Dissertação de Mestrado), 1997. p. 215.
} 
este espaço. Na tese defendida em 2002, Sérgio Oliveira, demonstra a tendência em encaminhar seus argumentos ao mercado, principalmente quanto às barreiras impostas por eles:

A maior dificuldade encontrada à inserção da tecnologia fotovoltaica pode ser traduzida pelo seu ainda incipiente mercado. Essa é uma decorrência do alto custo da energia por ela gerada. Nesse sentido, enfrenta-se a seguinte dificuldade: a tecnologia solar não tem mercado por ser cara e ainda é cara por não ter mercado. ${ }^{164}$

O discurso científico localiza e enquadra os principais atores que suas redes abrangem. O foco da biomassa de cana-de-açúcar ou então o da energia solar são similares, buscam aqueles que detêm o poder das decisões e o devido financiamento para promover as tecnologias, sem que haja, no entanto, necessariamente uma crítica incisiva à postura destes, apenas a indicação das barreiras que devem ser superadas para a introdução de uma nova tecnologia energética.

As críticas aos direcionamentos das concessionárias privadas ou estatais e ao próprio mercado energético existem nos trabalhos do PIPGE. Os textos e artigos que são enviados para periódicos ou anais de eventos contêm este elemento, somado ao papel de divulgador das pesquisas. Muitos desses trabalhos foram para eventos internacionais ou então revistas especializadas na área. Estes fatores podem significar que haveria um espaço maior de debate e crítica fora do país. Em texto para uma conferência realizada nos EUA no ano de 1999, Suani Coelho e outros revelam que, apesar do setor energético quase totalmente privatizado, e mesmo com a existência dos produtores independentes, não havia ainda o incentivo para a produção de energia elétrica a partir de biomassa.

\footnotetext{
${ }^{164}$ OLIVEIRA, Sérgio Henrique Ferreira de. Geração distribuida de eletricidade: inserção de edificações fotovoltaicas conectadas à rede no Estado de São Paulo. São Paulo: PIPGE (Tese de Doutorado), 2002. p. 14.
} 
[...] Atualmente, com a privatização do setor elétrico brasileiro, não existem oficialmente preços impostos para as vendas de eletricidade para as companhias. O PIE [Produtor Independente de Energia] pode vender para outros consumidores, mas as tarifas definidas para a transação ainda estão altas e não incentivam o processo. ${ }^{165}$

Sendo que a causa principal dessa falta de incentivos estaria na descentralização da produção, como revelam os autores em outro texto, este de 1998, para uma conferência européia: "Também do ponto de vista das companhias, não existe interesse em tal processo visto como de 'perda de poder' ou 'perda de clientes' [...]."166 Ainda assim, divulgam a biomassa como um grande programa energético brasileiro, indicando sua importância à matriz do país, principalmente em relação ao combustível:

A biomassa tem um papel importante na sociedade moderna. No Brasil particularmente, esta representação é bem significativa: a biomassa corresponde em $28 \%$ do total da energia primária, maior que a produção de combustíveis fósseis [...] Alem disso, o uso da biomassa nos setor sucro-alcooleiro coloca o Brasil em uma situação relevante como responsável por um dos mais importantes programas de energia renovável no mundo. ${ }^{167}$

Do mesmo modo, os "papers" sobre energia solar abordam a relação entre a tecnologia e os órgãos controladores do setor energético. Porém, apesar da barreira do mercado e a possível descentralização na geração elétrica, a energia solar apresenta uma proximidade com a política, principalmente pelos programas sociais de eletrificação que

\footnotetext{
165 "[...] Presently, with the privatization of Brazilian electric sector, there are no prices officially imposed for the electricity sales for the utilities. The IPP can sell to other consumers but the tariffs defined for wheeling are still quite high and do not incentive such process." COELHO, Suani T. et al. Proposals for the improvement of biomass participation in the Brazilian energy matrix: the "Declaration of Recife". In: IV Conferência de Biomassa das Américas. Oakland/EUA: Agosto, 1999. p. 3.

166 "Also from the utilities point of view, there is no interest in such process, seen as 'loss of power' or 'loss of client' [...]" COELHO, Suani T., BOA NOVA, A.C. e ZYLBERSTAJN, David. Social and political aspects of a biomass-origin cogeneration program. The Brazilian experience. In: X European Conference - biomass of energy industry. Junho, 1998. p. 1184.

167 "Biomass plays an important role on a modern society. In Brazil, particularly, its figures are quite significant: biomass corresponds to $28 \%$ of total primary energy, higher than fossil fuels production [...] Moreover, biomass use in sugar/alcohol sector places Brazil in a relevant situation as responsible for one of the most important renewable energy programs worldwide." COELHO, Suani T. e MERCEDES, Sonia S. P. Brazilian policy for greenhouse gas mitigation: the national reference Center on Biomass CENBIO. In: II EETIC Teams Meeting. Novembro, 1998. p. 1.
} 
promovem a fonte energética. Novamente em um texto enviado para uma conferência na Europa no ano de 1997, Roberto Zilles, Adnei Melges e Fernando Prado Jr. apresentam as parcerias com o Estado de São Paulo e divulgam a pesquisa, mediante menção de dois programas de energia solar, o primeiro voltado para a área de saúde: “Um dos programas, desenvolvido em parceria com a Secretaria Estadual de Saúde de São Paulo, garante energia para sete postos de saúde, para iluminação, vacina e as necessidades de refrigeração do soro [...]." "168 Já o segundo programa que citam se refere a um projeto de eletrificação em áreas de preservação do Estado, pois tais locais, por suas características ambientais, não permitiam a adesão destas à rede elétrica normal

[...] Esta consistiu na eletrificação de onze centros comunitários na Estação Ecologia Juréia-Itatins, o mais importante parque de preservação da Mata Atlântica no Estado de São Paulo. Este programa totalizou $6,2 \mathrm{KWp}$ de eletricidade. ${ }^{169}$

Os pesquisadores traziam para os textos os atores que estavam envolvidos nas pesquisas sobre as tecnologias. Mas não somente orgãos públicos, Governo ou companhias privadas tinham espaço dentro do discurso. As pessoas que iriam utilizar a tecnologia no seu cotidiano foram também o destaque das argumentações, principalmente nas pesquisas sobre energia solar. Os estudos no PIPGE que abordam a energia solar fotovoltaica, principalmente a partir de 1997, têm a preocupação em realizar o trabalho de campo para conhecer as comunidades a serem atendidas, como também, após a inserção da tecnologia, os resultados da utilização dos sistemas fotovoltaicos. A documentação sobre este tipo de atividade neste núcleo de pesquisas do

\footnotetext{
168 "One of the programs, developed in partnership with São Paulo State Health Secretary, granted electric energy to seven health stations for their illumination and vaccine and serum refrigeration needs [...]." ZILLES, Roberto, ANDRADE, Adnei Melges e PRADO Jr. Fernando Amaral do. Solar home system programs in São Paulo State, Brazil: utility and user associations experiences. In: XIV European Photovoltaic Solar Energy Conference. Barcelona: Espanha, Junho, 1997. p. 932.

169 "[...] It consisted in the electrification of eleven community centers at the Juréia-Itatins Ecological Station, the most important Mata Atlântica (Atlantic Forest) preservation park in São Paulo State. This program totalized $6.2 \mathrm{kWp}$ power." Idem. p. 932 (Grifo do Autor).
} 
Programa é mais considerável que as provenientes do grupo da biomassa, me levando a considerar que a atividade de campo e a preocupação de entender os atores que irão utilizar a tecnologia foi uma determinação das orientações deste tipo de pesquisa em energia solar dentro do PIPGE.

Entende-se que isso ocorreu pelo tipo de direcionamento, como veremos a seguir, para a pequena escala,na utilização do equipamento e pelo tipo de meio no qual a energia solar foi colocada para estas comunidades: os programas sociais de eletrificação. Provavelmente, a iniciativa de partir para o campo deveu-se às falhas constatadas nos projetos sociais na qual participavam, que serão tratados a diante nesta dissertação. Portanto, resolver os problemas que foram enfrentados nestes projetos acabaria os levando ao reconhecimento do espaço de aplicação da tecnologia.

Segundo os pesquisadores do Programa, para as populações atendidas, a tecnologia permitiu a mudança no padrão de vida e também de consumo de seus habitantes; neste sentido, a introdução de uma tecnologia afetou diretamente o cotidiano dessas pessoas, pois se ao mesmo tempo em que "Levar energia as áreas isoladas e rurais surge como um desafio, uma conquista de cidadania, dentro de uma sociedade com desigualdades sociais e econômicas [...]." ${ }^{170}$, como exaltou Marcos Paulo Serpa do PIPGE em sua tese de 2001, também houve outras conseqüências da aplicação tecnológica nestes casos. E estas são resultado do formato em que os projetos sociais de eletrificação foram configurados, que provavelmente teve os mesmo problemas, apesar dos estudos de campo, que os projetos já mencionados de 1992. Esta comparação ficaria obtusa, pois não tenho informações sobre os acontecimentos que marcaram os fracassos destes programas, nem provenientes dos pesquisadores do PIPGE e nem de literatura oriundos de meios governamentais. Portanto, como antes citado, teriam tido

\footnotetext{
${ }^{170}$ SERPA, Paulo Marcos Noronha. Eletrificação fotovoltaica em comunidades caiçaras e seus impactos socioculturais. São Paulo: PIPGE (Tese de Doutorado), 2001. p. 35
} 
dificuldades com a realidade local. E, como veremos, o mesmo ocorreu com os trabalhos deste tipo no PIPGE, será possível apenas supor a semelhança entre ambos.

Nos levantamentos de campo realizados pelos pesquisadores do Programa para teses e dissertações entre 1997 e 2002, consta que as regiões atendidas pela energia solar fotovoltaica, dentro do projeto social em que atuavam, ${ }^{171}$ seriam espaços nos quais as interações sociais se estabeleciam em torno de uma única forma de economia, seja a região costeira com a pesca entre os caiçaras, as áreas rurais e a sua função agropecuária e o parque ecológico da Juréia-Itatins, com a atividade de área de preservação. No entanto, alguns pesquisadores admitem certa variedade de atividades econômicas que diferenciariam comunidades de uma mesma região, conforme descreveu Federico Trigoso no ano 2000: “As comunidades rurais onde foram instalados os medidores de Ah pertencem aos municípios de Ilha Comprida e Cananéia. Estas comunidades mostram perfis sociais, econômicos e culturais diferentes [...]". ${ }^{172}$ Mesmo assim, foram tratadas, em sua maioria, como se não houvesse diferenças significativas.

Os pesquisadores do PIPGE apontaram os personagens que poderiam exercer o papel de lideranças em cada uma das comunidades, sendo que a figura do chefe se tornava o principal mediador entre os pesquisadores, a tecnologia e os habitantes. $\mathrm{O}$ trabalho de campo se preocupava também com o tipo de consumo energético que cada comunidade atendida apresenta, os usos finais para cada habitante e a comparação entre o total consumido pelas comunidades de cada região. Como explica Federico Trigoso, este procedimento se torna necessário pois as configurações do sistema fotovoltaico dependem da demanda de energia a ser utilizado e consequentemente "[...] é de suma

\footnotetext{
${ }^{171}$ Este projeto é referente a uma parceria entre o Estado de São Paulo e o Laboratório de Sistemas Fotovoltaicos do Instituto de Eletrotécnica e Energia da USP, ligado ao PIPGE. Teve inicio no ano de 1995 e seu objetivo seria de levar eletricidade a comunidades isoladas e rurais do Estado.

${ }_{172}$ TRIGOSO, Federico Morante. Demanda energética em Solar Home Systems. São Paulo: PIPGE (Dissertação de Mestrado), 2000. p. 75.
} 
importância estabelecer um diagnóstico completo das famílias onde se pretende realizar o projeto [...]." 173

Os problemas na inserção da energia solar não estavam diretamente relacionados à tecnologia. Na maioria dos casos foram realizadas capacitações para que a população atendida pudesse manter os equipamentos, garantindo o suprimento de energia sem a necessidade do auxilio externo, ou então, os técnicos eram fornecidos pelo próprio projeto. No entanto, as relações sociais dentro das comunidades sofreram certo impacto pela introdução da energia fotovoltaica, consolidando-se também como uma espécie de instrumento de poder para aqueles que exerciam o papel de lideres em meio aos habitantes. "[...] Quando da instalação do sistema fotovoltaico [...]", explica Maria Julita Ferreira em sua análise no ano de 2002, a respeito dos projetos, “[...] a família desse responsável já ocupava um lugar de destaque, seja pelo nível de consciência política ou pelo exercício de sua cidadania em uma comunidade com elevado grau de isolamento [... $]^{\prime 174}$, ou seja, se destacaria dos demais habitantes por ser conhecedor de alguns mecanismos de funcionamento social, detendo o saber necessário para ser reconhecido pelos pesquisadores como o mediador entre a tecnologia e a população atendida, mas que, ao se tornar este personagem, o líder acaba por assumir por si próprio a função de controlar o acesso e a utilização do equipamento dentro da comunidade, promovendo atividades que estariam fora do contrato estabelecido para o uso da energia fotovoltaica. Como indica a mesma autora, com o exemplo de certa comunidade, quando o líder aproveitava a tecnologia para outros fins que não prover de eletricidade as casas dos moradores, lucrando com o equipamento e o desviando do objetivo tratado por contrato de concessão de seu uso.

\footnotetext{
${ }^{173}$ Idem. p. 13.

${ }^{174}$ FERREIRA, Maria Julita Guerra. Experiência de projetos fotovoltaicos no estado de São Paulo: modelagem para planejamento energético em comunidades isoladas. São Paulo: PIPGE (Tese de Doutorado), 2002. p. 74.
} 
[...] Na vistoria realizada em 1993 foi constatado que os sistemas fotovoltaicos também eram utilizados para recarregar baterias de embarcações. Não é possível avaliar até que ponto esses serviços eram realizados indiscriminadamente [...]. ${ }^{175}$

Partindo da leitura dos textos, percebo que a liderança foi estimulada em alguns casos pelos próprios pesquisadores, quando da formação de uma Associação de Moradores, evidenciando, a preferência dos projetos em estabelecer um personagem para o diálogo entre o conhecimento científico e tecnológico e os habitantes leigos. Isto pode significar que houve uma definição de um perfil característico para um líder comunitário, responsável pela tecnologia. Os pesquisadores do PIPGE teriam se baseado para defini-lo nas próprias estruturas sociais tecidas dentro das comunidades, assim como considerou o então doutorando em 2001 Paulo Serpa: “[...] no contexto das lideranças locais, há questões ainda não resolvidas como a representatividade baseada nas relações de parentesco, resquícios de autoritarismo e baixa participação política das mulheres." 176

Neste sentido, podemos também compreender que, se houve a constatação de um exercício de poder sobre o conhecimento tecnológico que extrapolou as funções préestabelecidas em contrato para tal atividade, por uma das partes pelo menos, devemos questionar conseqüentemente quem então detém o poder sobre tal ou qual equipamento, conhecimento cientifico ou procedimento técnico? As companhias energéticas? Os cientistas e pesquisadores? A sociedade? As populações atendidas? A partir de que momento um determinado conjunto de saberes deixa de ser propriedade de um grupo e passa a ser de uso livre para todos que necessitam deste conhecimento? Evidentemente que as chamadas lideranças das comunidades que utilizaram em beneficio próprio a tecnologia não devem ser isentas de responsabilidade sobre o mau uso de um

\footnotetext{
${ }^{175}$ Idem. p. 74 (SIC).

${ }^{176}$ SERPA, Paulo Marcos Noronha. Op. cit. 2001. p. 242.
} 
instrumento que deveria beneficiar a todos, mas se em primeiro lugar esses lideres são eleitos pelos próprios pesquisadores com a capacitação técnica, privilegiando sua presença, e, em segundo, adotam a postura de que o equipamento deve ser preservado da própria população, sendo que faz parte do projeto e não da comunidade, não estariam os cientistas também exercendo o poder sobre os demais, leigos nestes assuntos, deixando-os a mercê daqueles lideres?

Dessa forma, os pesquisadores do PIPGE em energias alternativas procuraram atuar junto ao atores que poderiam tomar decisões em relação à inserção de novas tecnologias na geração de energia. As pesquisas do Programa ficam centradas em casos específicos, novos espaços de atuação e a preocupação, principalmente, da energia solar, com os usuários do sistema. Os pesquisadores do PIPGE que buscam definir as áreas de atuação de suas pesquisas, pequena ou larga escala, estavam estendendo as redes que compunham seus laboratórios. Procuravam criar caminhos, e junto a estes, a possibilidade de atuar com os interessados em suas pesquisas, além do interesse próprio em se firmarem enquanto grupo de pesquisadores e também enquanto indivíduos, pois anseiam pelo reconhecimento do trabalho científico.

Portanto, os pesquisadores trazem ao discurso os atores envolvidos na pesquisa. Há uma repetição de temas e argumentos, o que pode ser considerada uma característica da produção científica desta linha de pesquisa do PIPGE. Sugiro também que isto indica que não haveria a necessidade de uma abordagem que esmiuçasse fatores externos às tecnologias envolvidas, devendo ficar no espaço estrito da técnica e suas implicações políticas e econômicas. Revelador de uma postura de ação estrita com órgãos e indivíduos que proporcionassem uma resposta direta às suas argumentações. 
3) Larga e pequena escala: diferentes objetivos no PIPGE para as fontes alternativas

Em 1992, a primeira dissertação defendida pela linha de pesquisa sobre energias alternativa era intitulada "Avaliação da cogeração de eletricidade a partir de bagaço de cana em sistemas de gaseificador/turbina a gás", na qual sua autora, Suani Teixeira Coelho, busca ampliar a presença do setor privado na geração energética, junto à expansão da matriz no país, que poderia ser realizada com o uso da biomassa. ${ }^{177}$ E no ano de 1993, temos a defesa do mestrado em energia solar de Maria Julita Guerra Ferreira, "Inserção da energia fotovoltaica no Brasil", cujo teor indica que a presença da tecnologia solar estava crescendo devido a eventos sobre o tema e que o mercado nacional cresceria com o barateamento de seu custo, proporcionado pelas pesquisas e desenvolvimentos da área. ${ }^{178}$

Essa tendência em nomear os trabalhos fazendo referência à introdução ou inserção das tecnologias se mantém até o final da primeira fase da literatura do Programa de 1992 até 1996. Mas isso não significa que tenha desaparecido completamente da literatura posteriormente produzida pelo Programa. Até o ano de 2002 podemos encontrar em dissertações, teses e textos para eventos e periódicos a preocupação em introduzir ou inserir as tecnologias no cenário energético do Estado ou País. A mesma pesquisadora Suani Teixeira Coelho, da dissertação de 1992, defende em 1999 o doutorado com o título de "Mecanismos para implementação da cogeração de eletricidade a partir da biomassa. Um modelo para o Estado de São Paulo" e publica em 1996, entre outros textos, para uma conferência européia em bioenergia " $A$

\footnotetext{
${ }^{177}$ COELHO, Suani T. Avaliação da cogeração da eletricidade a partir de bagaço de cana em sistemas de gaseificador/turbina a gás. São Paulo: PIPGE (Dissertação de Mestrado), 1992.

${ }^{178}$ FERREIRA, Maria Julita Guerra. Inserção de energia solar fotovoltaica no Brasil. São Paulo: PIPGE (Dissertação de Mestrado), 1993.
} 
preliminary analysis of mechanisms to improve biomass-origin co-generation in Brazil".

A partir da segunda fase, de 1997 a 2002, houve a iniciativa dos pesquisadores em estabelecer cenários específicos para as tecnologias. Cenários que poderiam definir os tipos de utilização para estas, assim como os usuários destes sistemas energéticos. A diferença vinha também do fato dos atores apresentarem uma postura crítica, embora limitada, a indicar alguns pontos negativos da tecnologia, e estudos de casos, diferentemente do primeiro momento no qual eles elaboravam cenários gerais para a análise dos objetos. Os pesquisadores também procuravam agregar estas tecnologias ao planejamento estadual em energia, e de forma notadamente incisiva a partir de 1998 com a crise energética nacional e o advento do apagão na região sul e sudeste do país, levando à premente necessidade de geração elétrica de emergência para suprir a demanda da região. Dessa forma, direcionavam a energia solar para a baixa escala de utilização e a biomassa de cana de açúcar para a larga escala dentro da matriz energética do Estado de São Paulo.

A larga escala seria a utilização da tecnologia para prover a matriz energética estadual ou nacional, contribuindo ou substituindo as principais fontes, comumente de origem fóssil, pela tecnologia em questão. Dessa forma, seria um aproveitamento de grande quantidade de energia a ser gerada, para exatamente compor o parque gerador e ter uma presença significativa no balanço energético. Por outro lado, a baixa escala procuraria a aplicação individualizada da tecnologia, casas, comércio, industrias, sem que, no entanto, fosse direcionada para grandes empreendimentos, inserindo-se em atividades de pouco consumo de energia.

Desde a década de 1980, no Brasil, tem se considerado a utilização da energia solar para eletrificação de comunidades isoladas, parques ecológicos, área rural. "Como 
se constata em diversos projetos de energia fotovoltaica, esta alternativa de geração de energia é compatível com as necessidades de comunidades carentes [...]", escreve em 2002 a doutorando do PIPGE, Maria Julita Guerra Ferreira. Isto porque a tecnologia solar possibilitaria trazer a estas populações "[...] níveis mínimos de conforto $e$ capacidade de produção, o que se traduz em consolidação de alguma renda e sua decorrente capacidade de participação do mercado de consumo." 179

O governo brasileiro introduziu esta tecnologia nas comunidades carentes do país, com o Programa de Desenvolvimento Energético dos Estados e Municípios (PRODEEM) do ano de 1995. Havia outros projetos sociais em funcionamento anteriormente no estado de São Paulo, como por exemplo, os projetos da Secretária Estadual de Energia e do Laboratório de Sistema Fotovoltaicos do Instituto de Energia e Eletrotécnica da Universidade de São Paulo (LSF/IEE), que juntos promoveram estudos de eletrificação na região costeira do estado e a implantação de unidades fotovoltaicas nas comunidades da região de Lagamar. ${ }^{180}$ Além disso, no Brasil, havia desde 1992 a parceira com os EUA em um programa do Departament of Energy deste país e outro, com a Alemanha, no chamado Projeto Eldorado, que durou de 1995 a 1997. Porém, como admite a Maria Julita Ferreira do PIPGE, estes programas que contavam com parceiros internacionais não foram bem sucedidos, pois os projetos inseridos nas comunidades não se encaixaram com a realidade local, conseqüentemente não produzindo os resultados esperados. Mas, como contraponto, foram "[...] programas de maior impacto [...]", pois teriam mostrado "[...] às empresas de energias e às

\footnotetext{
${ }^{179}$ FERREIRA, Maria Julita Guerra. Experiência de projetos fotovoltaicos no Estado de São Paulo: modelagem para planejamento energético em comunidades isoladas. São Paulo: PIPGE (Tese de Doutorado), 2002. p.114-115.

${ }^{180}$ Cf. SERPA, Paulo Marcos Noronha. Eletrificação fotovoltaica em comunidades caiçaras e seus impactos socioculturais. São Paulo: PIPGE, (Tese de Doutorado), 2001; FERREIRA, Maria Julita Guerra. Op. cit. 2002.
} 
autoridades governamentais a viabilidade técnica da opção fotovoltaica, para atendimento das necessidades em comunidades isoladas e no meio rural". ${ }^{181}$

Se os exemplos mostraram para as autoridades e a tecnocracia das empresas energéticas que era uma opção investirem neste tipo de programa, não poderemos responder com certeza. Entretanto, no final de 1994, mediante um decreto do presidente Itamar Franco, foi criado o PRODEEM, tendo como objetivos: tornar viável a inclusão de sistemas energéticos em comunidades isoladas que não fossem atendidas pela rede elétrica, promover a descentralização da geração elétrica, pois a produção seria no próprio local de consumo, não passando pelas companhias de energia, além de promover a tecnologia nacional e "complementar a oferta de energia dos sistemas convencionais com a utilização de fontes de energia renováveis descentralizadas". ${ }^{182} \mathrm{O}$ texto do PRODEEM assemelhava-se com as perspectivas dos projetos sociais, tendo outras nações como parceiras na aplicação da tecnologia.

Segunda, Maria Julita Ferreira, o PRODEEM possibilitaria às fontes alternativas uma participação, embora pequena, na geração elétrica no país, enquadrando-se no tipo de utilização almejada inicialmente pelos pesquisadores do PIPGE em energia solar. Em 1999, o programa governamental ganhou um novo aliado, o Banco Interamericano de Desenvolvimento, permitindo a ampliação do espaço de atuação do PRODEEM e sua integração com outros projetos, criando um plano de ação para que o controle de suas atividades fossem passadas para o âmbito regional, quando até então ficavam os Estados responsáveis por toda a organização do projeto de eletrificação, e assim, aproximar os personagens que seriam os beneficiados com a tecnologia, permitindo a integração entre suas necessidades e as possibilidades de ação do programa. ${ }^{183}$

\footnotetext{
${ }^{181}$ FERREIRA, Maria Julita Guerra. Op. cit. 2002. p. 8-9.

${ }^{182}$ Decreto $\mathrm{S} / \mathrm{N}^{\mathrm{o}}$, de 27 de dezembro de 1994.

${ }^{183}$ FERREIRA, Maria Julita Guerra. Op. cit. 2002.
} 
Devido ao fato de existirem, na década de 1990, diversos projetos de eletrificação fotovoltaica atendidos pelo PIPGE (somente no Estado de São Paulo, foram pelo menos cinco $^{184}$ ) faremos uma abordagem em conjunto, pois as características, suas vantagens, usos e problemas que os pesquisadores do Programa apresentaram podem ser arrolados de forma geral para todos os casos.

A utilização da energia solar nas comunidades isoladas e na zona rural se caracterizou pelo consumo nas tarefas cotidianas: cocção, bombeamento de água, iluminação, aquecimento etc. Para a pesquisadora Maria Julita Ferreira, os projetos que visam à eletrificação destes espaços mediante o uso da tecnologia fotovoltaica possibilitariam romper com o isolamento energético dessas populações, além do fato de proporcionar a descentralização da atividade de geração energética que:

[...] é de fundamental importância para o estabelecimento das tecnologias baseadas na exploração das fontes renováveis não convencionais, como o caso da energia fotovoltaica, pois sua possibilidade de expansão de mercado, até o advento dos sistemas interligados à rede era a expansão de projetos autônomos de eletrificação rural, ou seja, levar os serviços de energia a comunidades isoladas. 185

Com uma vertente tecnológica no PIPGE servindo diretamente para atender sua capacidade enquanto projeto social, compreendo que a energia solar fotovoltaica acaba tendo um uso diferenciado no país, e em especial no Estado de São Paulo, ao ser aplicada em áreas de pouco consumo, o que acaba tornando-a uma alternativa para geração descentralizada e para a inclusão social no Brasil, levando as melhorias e os benefícios da eletricidade para comunidades isoladas e a zona rural, onde não seria

\footnotetext{
184 O Projeto Juréia-Itatins de 1993; Projeto Ecowatt de 1997; Projeto Eldorado de 1995 a 1999; O Programa Luz da Terra de 1996; A parceria entre PIPGE e uma Ong espanhola Era-Aedenat, que em 2002 gerenciava projetos no Vale do Ribeira. Inclusive consta de um projeto pioneiro no estado que ocorreu de 1985 a 1989, cujo mote era a eletrificação fotovoltaica em postos de saúde neste mesmo Vale do Ribeira.

${ }^{185}$ FERREIRA, Maria Julita Guerra. Op. cit. 2002. p. 130.
} 
viável economicamente o uso da rede de transmissão elétrica. Assim, se enquadram nas perspectivas tanto do Governo Federal, mediante o exposto no Decreto do PRODEEM e também naquilo que os pesquisadores tinham ou aceitaram como as possibilidades de aplicação da tecnologia fotovoltaica.

Quanto a este direcionamento, possivelmente suas raízes estejam muito antes da criação do próprio PIPGE, pois percebo que os pesquisadores do Programa seguiam a mesma linha de pensamento exposta pelo Professor José Goldemberg em 1977, ao dizer em conferência para a Câmara dos Deputados sobre o aproveitamento da energia solar no país que: "[...] Há quantidades imensas de energia que nos atingem todo o dia, provenientes do sol e o que ocorre é que essa forma de energia não é adequada para o tipo de civilização que constituímos [...]." e na continuação da fala, diz que esta seria e foi mais proveitosa para uma "[...] sociedade agrícola [...]." " Assim, talvez definiu em 1977 os direcionamentos que seriam adotados pelo PIPGE, afinal o Programa foi criado por ele, para a energia solar fotovoltaica.

Mesmo que, na primeira dissertação sobre energia solar defendida pelo Programa em 1993, a pesquisadora Maria Julita Ferreira entenda que a tecnologia fotovoltaica, devido ao seu desenvolvimento, “[...] tem aberto novas perspectivas para a solução do problema energético em larga escala." ${ }^{187}$ esta posição não foi levada adiante, sendo abandonada pelos pesquisadores em trabalhos posteriores. Até mesmo esta autora, em seu doutorado, parte para a pesquisa junto a comunidades isoladas, admitindo inclusive a diferenciação legada pelo setor energético nacional tanto para a eletrificação rural quanto para as energias renováveis, sendo que para ela: “[...] $E$ sintomático que geralmente estão vinculadas estruturalmente a áreas de planejamento,

\footnotetext{
${ }^{186}$ CÂMARA DOS DEPUTADOS. Desenvolvimento e importância da tecnologia nacional. Brasília: Centro de Documentação e Informação/Coordenação de Publicações, 1978. p. 281.

${ }^{187}$ FERREIRA, Maria Julita Guerra. Op. cit. 1993. p. 22-23 (Grifo Nosso).
} 
onde são colocadas todas as atividades que o setor não sabe muito bem como classificar $[\ldots] ., " 188$

Já as perspectivas em torno da biomassa de cana de açúcar giravam em torno de um projeto que, embora possa parecer ambicioso frente à energia solar, pode ser compreendido como simples, a larga escala. Durante o período abordado nesta dissertação, de 1992 a 2002, não houve mudanças significativas no argumento dos pesquisadores quanto ao destino que procuravam dar a tecnologia em biomassa. A larga escala em biomassa no Brasil vem desde a década de 1970, quando se inicia a produção de álcool combustível dentro do Proálcool, a que a cogeração com o bagaço de cana-deaçúcar, principal estudo do PIPGE, se filia como sendo o resultado e solução do programa, assim como expomos anteriormente. A larga escala na geração energética pela biomassa se daria pelo "[...] enorme potencial de geração existente [...]" que ainda seria desperdiçado no ano 2000, por conta do bagaço ser queimado pelas usinas “[...] por falta de outras opções [...]." ${ }^{189}$ Os empreendimentos em larga escala, deveriam vir a substituir o petróleo ou ser um elemento a mais neste processo para a renovação da matriz energética nacional, lembrando que este também seria o plano inicial para o Programa do Álcool em 1975.

A larga escala se apresentava na década de 1990 como uma opção viável para os pesquisadores e também como um meio de reaproveitar as sobras da safra da cana; o bagaço e até mesmo a vinhaça seriam cogitados para a cogeração nas indústrias sucroalcooleiras. A vinhaça, cabe fazer uma ressalva, aparece apenas na dissertação de Reinaldo Alves Almança de 1994, não aparecendo outros trabalhos a respeito, nem artigos ou eventos após este ano, provavelmente pela própria postura demonstrada pelo

\footnotetext{
${ }^{188}$ Idem. p. 4.

189 COELHO, Suani T. Questão de bom senso. In: Agroanalysis. Rio de Janeiro: Fundação Getulio Vargas, 2000. p. 31.
} 
pesquisador ao chegar a conclusão que "A possibilidade de utilizar a vinhaça da canade-açúcar na geração de eletricidade é como pode ser constatado neste estudo, perfeitamente viável sob o aspecto técnico, embora impraticável sob o aspecto econômico [...]." ${ }^{190}$ Como podemos observar, uma afirmação que se diferencia da maioria dos outros trabalhos científicos, ao admitir que seu objeto, a vinhaça, não seria competitiva em relação a outros meios de produção energética, enfraquecendo seu enunciado frente às companhias e usinas do setor, pois, como veremos adiante, as barreiras econômicas, de preço de compra da eletricidade e dos custos de instalação da tecnologia de cogeração, são os pontos principais nas controvérsias a respeito da biomassa.

Como escreveu em sua dissertação de 1992, Suani Coelho: "Deve ser considerado o fato de que o objetivo principal do setor sucro-alcooleiro é a geração de vapor para consumo no processo de fabricação de açúcar e álcool [...]. "191 Talvez por conta disto que a fonte energética não foi mais pesquisada no Programa; afinal exigiria do empresário um investimento maior na compra de equipamento. Interessante notar que a tecnologia para a vinhaça e para o bagaço seria a mesma, mas os pesquisadores deste último encobrem a questão.

Optar pela larga escala como objetivo para a biomassa levava os autores a trazerem diversos aliados que pudessem auxiliar na iniciativa de um programa amplo para a fonte energética. Assim, por necessitar de atores que fortalecessem seu enunciado, os pesquisadores do Programa não realizaram uma abordagem sobre a tecnologia de forma que seus contrapontos fossem levados em conta. Apenas relacionavam as controvérsias que surgiam de fora da pesquisa, ou seja, das concessionárias e do governo, que por vezes iam de encontro ao seus argumentos; neste

\footnotetext{
${ }^{190}$ ALMANÇA, Reinaldo Alves. Op. cit. 1994. p. 123.

${ }^{191}$ COELHO, Suani T. Op. cit. 1992. p. 30.
} 
caso, tais elementos "negativos" ao enunciado eram considerados pelos pesquisadores como barreiras à fonte energética.

Neste sentido, entre os pesquisadores do PIPGE, a larga escala na cogeração com o bagaço da cana não apresentava os problemas econômicos e nem mesmo os tecnológicos, mas entre estes apareciam os problemas políticos relacionados à legislação vigente, que em 1996 levou os pesquisadores Zylbersztajn e Coelho a dizer que "[...] apesar da unanimidade de opiniões quanto aos seus benefícios, ainda não existem mecanismos especiais para a implementação de um programa de cogeração em larga escala no país." 192 Porém, em relação a mecanismos de incentivos, tal como as políticas públicas, as pesquisas apresentaram um exemplo, citado anteriormente, que foi tema recorrente dos argumentos na literatura do PIPGE. No ano de 1992, uma espécie de contrato firmado no Estado de São Paulo, que não se concretizou, foi o estabelecimento de um Protocolo de venda dos excedentes da geração elétrica das usinas para as concessionárias, ainda públicas, fazerem a distribuição na rede e ao mesmo tempo aliviar a demanda de energia nos horários de pico do consumo no Estado de São Paulo.

A respeito deste protocolo firmado, temos apenas indícios, não sendo possível encontrá-lo para análise. Estes indícios partem daquilo que os pesquisadores do Programa escreveram sobre o documento. Em sua análise do Protocolo, no mesmo ano da sua assinatura, em 1992, Suani Coelho acreditava que haveria um incremento no número de usinas que empregariam o processo de cogeração, por haver naquele momento este mecanismo legal que iria beneficiar os produtores, pois venderiam a

\footnotetext{
192 COELHO, Suani T. e ZYLBERSZTAJN, David. Barreiras e mecanismos de implementação à cogeração de eletricidade a partir de biomassa. IN: III Congresso Brasileiro de Planejamento Energético. São Paulo: Sociedade Brasileira de Planejamento Energético, 1998. p. 159
} 
energia excedente à “[...] preços realistas [...]”"193; entretanto, seis anos depois, 1999, em sua tese a mesma autora reconhece que

O Protocolo de Cogeração, assinado em 1993 entre o setor sucroalcooleiro e as concessionárias do Estado de São Paulo, apresentou resultados tímidos, quando comparados com as expectativas iniciais (3.000 MW instalados, $1.300 \mathrm{Gw} / \mathrm{h}$ até o ano de 2000). ${ }^{194}$

Os pesquisadores do PIPGE procuravam dessa maneira se aproximar tanto da indústria quanto das companhias energéticas, estabelecendo parâmetros para aquilo que seria ideal para o setor sucro-alcooleiro no quesito de preços de venda do $\mathrm{kW}$ e das concessionárias realizando estudos sobre as possibilidades do uso desta matéria-prima na matriz energética do Estado de São Paulo. Inclusive, a dificuldade em estabelecer os parâmetros para o Protocolo, além de colocá-lo efetivamente em funcionamento, viria da mentalidade "conservadora", que os Pesquisadores do Programa atribuem ao governo do Estado de São Paulo. Este adjetivo pode ser encontrado, principalmente, em Suani Teixeira, ao afirmar que este adota uma mentalidade que preferiria o uso das fontes tradicionais em detrimento das energias alternativas.

Entretanto, o que chama a atenção nos textos do PIPGE, sendo sobreposto por outros argumentos, foi a postura do próprio produtor de energia, dos usineiros, que em contraponto ao "conservadorismo" político, criava um clima de dúvida por parte do setor energético, principalmente em relação ao procedimento para garantir os preços de venda,

[...] Há indústrias que possuem uma capacidade de auto-geração maior do que aquela com que efetivamente operam pois, além do aspecto

\footnotetext{
${ }^{193}$ COELHO, Suani T. Op. cit. 1992. p. 33.

194 COELHO, Suani T. Mecanismos para implementação da cogeração de eletricidade a partir da biomassa: um modelo para o estado de São Paulo. São Paulo: PIPGE (Tese de Doutorado), 1999. p. 46. (Devido à discrepância quanto ao ano de firmado o Protocolo, 1992 ou 1993, preferimos adotar o ano de 1992, já que a dissertação de Suani Coelho foi defendida neste ano, portanto, já existiria este documento e entendemos que na tese tenha se equivocado quanto à datação.)
} 
econômico, temem que a concessionária (diante de uma perspectiva de crise) imponha reduções na eletricidade vendida [...]. ${ }^{195}$

Segundo Suani Teixeira, o Protocolo criaria as condições para a almejada introdução da cogeração em larga escala no contexto do cenário energético do Estado de São Paulo, porém as ações dos atores envolvidos teriam dificultado atingirem as metas estabelecidas. Revelando também que as barreiras não são políticas em sua maioria, como afirmam os pesquisadores em artigos de 1997 em diante, mas deveriam incluir a postura dos produtores em não cumprir os acordos firmados, por conta de interesses próprios. ${ }^{196}$ Mas não relacionarem a barreiras políticas pode também ter outros sentidos, relacionados principalmente às perspectivas que tinham sobre determinada iniciativa governamental.

Ilustrativo deste ponto foi à postura adotada pelos pesquisadores do PIPGE que trabalhavam com energias alternativas durante o processo de privatizações. Inicialmente apresentaram expectativas positivas ao cenário que se esboçava, em relação aos leilões das estatais e ao mercado de energia que estava por se concretizar, com as possíveis expansões e também pela almejada diversificação da matriz energética nacional. ${ }^{197}$ Podemos encontrar esta posição nos trabalhos sobre a biomassa, que tinham enquanto proposta a utilização em larga escala no parque energético paulista, quando entendiam que os investimentos privados poderiam auxiliar o setor em crise. ${ }^{198}$ Mas isto não

\footnotetext{
${ }^{195}$ Idem. p. 38.

${ }^{196}$ Cf. COELHO, Suani T., VARKUlya JR. Américo, PALETTA, Carlos Eduardo M. e SILVA, Orlando Cristiano da. A importância e o potencial brasileiro da cogeração de Energia a partir da biomassa. In: Gazeta Mercantil/Seminário "Cogeração De Energia". São Paulo, outubro, 2001. s/p.; ZYLBERSZTAJN, David e COELHO, Suani T. Op. cit. 1998.

${ }^{197}$ Cf. COELHO, Suani T. Avaliação da cogeração da eletricidade a partir de bagaço de cana em sistemas de gaseificador/turbina a gás. São Paulo: PIPGE (Dissertação de Mestrado), 1992; FERREIRA, Maria Julita Guerra. Inserção de energia solar fotovoltaica no Brasil. São Paulo: PIPGE, (Dissertação de Mestrado), 1993; ALMANÇA, Reinaldo Alves. Avaliação do uso da vinhaça da cana-de-açúcar na geração de energia elétrica (Estudo de Caso). São Paulo: PIPGE, (Dissertação de Mestrado), 1994.

${ }^{198}$ VELÁZQUEZ, S. G; COELHO, S. T. \& ZYLBERSZTAJN, D. Cogeneration in Brazilian pulp and paper industry from biomass-origin to reduce $\mathrm{CO}_{2}$ emissions. In: Developments in thermo chemical biomass conversion. Canadá, Vol. III, maio, 1996. pp. 1073-1085.
} 
significou que tal acontecimento tenha influenciado os textos e as análises dos pesquisadores do PIPGE, sobre o setor energético e a tecnologia em fontes alternativas. São poucos os trabalhos que se referem às privatizações, o que leva a entender que este processo, embora significativo para o tipo de pesquisa que elaboravam, foi colocado em segundo plano na produção, pois não era interessante tomar uma postura crítica sem que fosse finalizada a venda das estatais, seguindo a postura do próprio governo brasileiro.

O contrário disso ocorreu quando, nos anos que se seguiram ao estabelecimento das concessionárias privadas, com as políticas e planejamentos definidos, os pesquisadores do Programa acabam por alterar suas perspectivas quanto ao papel dessas empresas para a aplicação das fontes alternativas. O foco passa para a crítica e o questionamento das barreiras e direcionamentos que tais empresas formulam contra a presença das fontes geradoras de eletricidade que saem de seu controle, ou seja, que promovem a descentralização da produção de energia elétrica em suas áreas de concessão. As críticas quanto à postura dessas empresas se agravaram quando os investimentos e expansões do parque energético, tal como esperado durante o processo de privatização, não ocorreram, e, além disso, houve também a desestruturação do planejamento integrado da matriz energética nacional. Portanto, as perspectivas para a utilização da biomassa em larga escala foram frustradas pela política empresarial que as companhias adotaram, cabendo neste momento a crítica aos processos de privatizações promovidas pelo governo federal.

Entendo que esta postura se justificaria, pois os pesquisadores da biomassa procuravam estabelecer cenários para a aplicação da energia, e em alguns momentos realizavam estudos de caso sobre os impactos econômicos da cogeração em determinadas usinas de São Paulo. Era necessário que o contexto fosse favorável para que o discurso da tecnologia voltado para o setor usineiro tivesse a base política. 
Durante as privatizações, a larga escala era viável, já que a perspectiva dos pesquisadores com o mercado de energia criava a possibilidade de novos geradores de energia, tal como os Produtores Independentes de Energia (PIE), não cabendo a crítica a ações governamentais neste sentido. Mas quando perceberam que o contexto mudou desfavoravelmente a seus objetivos, não se concretizando a abertura do mercado de larga escala para a biomassa, coube a crítica às companhias privadas e ao Governo Federal.

Exemplo da relação entre contexto favorável ou não e a conseqüente continuidade nas atividades são as pesquisas do PIPGE sobre a utilização de biomassa na Amazônia. Podemos encontrar este tipo de trabalho em artigos sobre as aplicações da biomassa como combustível para comunidades isoladas na Amazônia, dois destes publicados no ano de 1994 e um em 2001. Nestes textos a motivação de trabalhar com a Região Norte, no inicio do século XXI, viria do fato de que em muitas partes deste espaço a geração era "[...] exclusivamente baseada em óleo diesel [...]"199 e também haveria o problema da poluição ocasionada por este tipo de combustível, detalhe que com a utilização da biomassa seria sanado, além de contribuir com uma questão estratégica considerada pelos pesquisadores do PIPGE, a descentralização da geração elétrica, como afirmou Suani Coelho e outros em 2001

[...] Aliás, esta vantagem da geração localizada é uma característica geral da utilização de resíduos. Outro ponto a ser considerado é a descentralização na distribuição da biomassa, o que permite a geração descentralizada com todas as suas vantagens estratégicas. ${ }^{200}$

Os artigos de 1994, ambos publicados em eventos internacionais, um na Bolívia e outro na Áustria, não diferem significativamente do argumento que seria utilizado em

\footnotetext{
${ }^{199}$ COELHO, Suani T., VARKULYA JR. Américo, PALETTA, Carlos Eduardo M. e SILVA, Orlando Cristiano da. Op. cit. 2001. s/p.

${ }^{200}$ Idem.
} 
2001. Apenas se referindo às decisões e relatórios brasileiros sobre a região durante a ECO-92, ressalta o papel das queimadas e a substituição da floresta por áreas de agricultura, e que poderiam ser utilizados os resíduos do Buriti e do óleo de Palma na cogeração energética para a região, pois seriam cultivados por famílias em pequenas vilas no interior da floresta. ${ }^{201}$

Entretanto, não foi possível encontrar nenhum resultado para as propostas do PIPGE em relação a biomassa na Amazônia e nem mesmo uma literatura quantitativa que fizesse transparecer os esforços neste sentido; inclusive, os dois textos de 1994 têm praticamente o mesmo teor, alterando tal ou qual parágrafo de um evento para outro. Sugere, por fim, que o papel da pequena escala foi secundário na argumentação, não tendo contexto favorável, surgindo quando fosse conveniente para os autores, incluindo um argumento diferente em seus trabalhos, embora não sendo a preocupação de suas pesquisas no período.

4) As tecnologias de energias alternativas: energia solar e biomassa de cana

No PIPGE, a ação de convencer, de provocar o interesse para a tecnologia e suas pesquisas, está presente em suas teses e dissertações. Os argumentos utilizados, as referências bibliográficas, os dados e equações, fazem parte das estratégias que utilizam para trazer seus leitores, principalmente o público alvo dos trabalhos, no caminho que desejam. O ato de convencer, componente da prática dos cientistas, atua na elaboração dos enunciados científicos da década de 1990 e início do século XXI.

\footnotetext{
${ }^{201}$ Cf. ZYLBERSZTAJN, David; IENO, Gilberto O. e COELHO, Suani Teixeira. Biomass in Amazonia and electricity generation. In: I Seminário Internacional de Energias Renovables. Bolivia, Setembro, 1994. E também ZYLBERSZTAJN, David; IENO, Gilberto O. e COELHO, Suani Teixeira. Electricity production in Amazonia from biomass crops residues. In: Biomass for Energy, Environment, Agriculture and Industry. Viena/Austria. Outubro, 1994.
} 
Neste período, anos de 1992 a 2002, as tecnologias para cogeração com biomassa de cana-de-açúcar e a energia solar, que apesar de serem conhecidas anteriormente, ainda eram distantes da realidade das pessoas. Segundo o Balanço Energético Estadual de São Paulo com ano-base 1995, a necessidade de energia no Estado, registrada no período de 1992 a 1995, cresceu 5\% ao ano. ${ }^{202}$ Dentro desta perspectiva de crescimento da necessidade de geração energética, o uso da biomassa para a cogeração de eletricidade nas usinas sucro-alcooleiras tinha sua tecnologia, em 1992, tratada na dissertação de Suani Coelho, pesquisadora do PIPGE, enquanto uma "possibilidade promissora" sendo que "[...] O excedente de eletricidade gerado pode ser vendido às concessionárias, contribuindo para suprir as crescentes necessidades da demanda." 203 Já no caso da energia solar fotovoltaica, Maria Julita Ferreira, em sua dissertação de 1993, aborda o fato de que estaria crescendo o interesse por esta tecnologia: "É notável, frente à situação anterior de quase total desinteresse pelo assunto, o impulso que a geração de energia elétrica por conversão fotovoltaica de energia solar vem recebendo nos últimos 3 anos no país." 204

Dois elementos podem ser considerados comuns na literatura do PIPGE em relação ao estado da arte da tecnologia fotovoltaica: sua elevada maturidade e confiabilidade para os processos aos quais seria destinada. Encontramos essa afirmação em vários momentos da produção científica do Programa. Em 1998, num congresso nacional de energia: "Atualmente a tecnologia fotovoltaica conta com um alto grau de maturidade o que se reflete em uma também elevada confiabilidade e eficiência no

\footnotetext{
${ }^{202}$ SÃO PAULO (ESTADO). Secretaria de Estado de Energia. Balanço Energético do Estado de São Paulo 1996 Ano-Base: 1995. CESP: São Paulo, 1996. p. 19.

${ }^{203}$ COELHO, Suani T. Op. cit. 1992. p. 02.

${ }^{204}$ FERREIRA, Maria Julita Guerra. Inserção de energia solar fotovoltaica no Brasil. São Paulo: PIPGE (Dissertação de Mestrado), 1993. p. 1.
} 
funcionamento dos sistemas [...]"205 ou então em uma dissertação de 1997: "A energia solar fotovoltaica é uma tecnologia razoavelmente nova, mas, por ter sido desenvolvida inicialmente para aplicações espaciais possui uma confiabilidade alta e grande durabilidade [...]"206 Estas afirmações constam apenas em textos divulgados em eventos nacionais, nas teses e dissertações, mostrando a característica de ser uma fonte em desenvolvimento no Brasil; nos textos em inglês enviados ao exterior, não costumam incluir a descrição as vantagens da tecnologia. No entanto, houve também casos em que os problemas tecnológicos foram descritos pelos pesquisadores, contrapondo a confiabilidade e maturidade dos sistemas, como a dissertação de Federico Trigoso, de 2000, ao considerar,

[...] a geração elétrica com tecnologia fotovoltaica no atual estágio de seu desenvolvimento, ainda é considerada uma forma de fornecimento energético com muitas limitações, relacionadas com os custos altos, com sua dependência às condições climáticas e com desempenho do sistema de armazenamento energético. ${ }^{207}$

Uma confiabilidade que depende de fenômenos externos ou do funcionamento do próprio sistema. Ou então, em 1998, quando reconhecem que não sabiam sobre o comportamento de uma vertente da tecnologia, o que chamam de Edificações Fotovoltaicas Conectadas à Rede (EFCR), no clima tropical, e problemas na segurança do equipamento, pois devido às características da fonte, não se aplicariam determinados tipos de mecanismos de segurança para evitar incêndios, por exemplo. ${ }^{208}$ Os argumentos contraditórios sobre a maturidade ou não dos sistemas fotovoltaicos e sua confiabilidade

\footnotetext{
${ }^{205}$ FEDRIZZI, Maria Cristina e SAUER, Ildo Luis. Pequenos sistemas de bombeamento fotovoltaico: análise da competitividade com outras opções. In: III Congresso Brasileiro de Planejamento Energético. São Paulo: Sociedade Brasileira de Planejamento Energético, 1998. p. 206 (Grifo Nosso).

${ }^{206}$ OLIVEIRA, Sergio H. F. Op. cit. 1997. p. 113 (Grifo Nosso).

${ }^{207}$ TRIGOSO, Federico Morante. Op. cit. 2000. p. 141.

${ }^{208}$ Cf. ZILLES, Roberto e OLIVEIRA, Sergio H. F. Pequenos geradores fotovoltaicos conectados à rede de distribuição de eletricidade. In: III Congresso Brasileiro de Planejamento Energético. São Paulo: Sociedade Brasileira de Planejamento Energético, 1998.
} 
parecem apenas auxiliar nas barreiras impostas pelas concessionárias para a introdução deste tipo de tecnologia. Em sua tese de 2002, o mesmo pesquisador que aponta as falhas no sistema EFCR, revela que as concessionárias incluem "[...] exigências desnecessariamente restritivas [...] quanto (i) às normas de segurança, e (ii) a qualidade da energia injetada na rede." Ou seja, os problemas inerentes a uma tecnologia confiável e matura não devem passar pela segurança de seu equipamento? Desconsiderar ou minimizar seus problemas seria uma forma de ocultar as possíveis críticas sobre a tecnologia?

Ocultar os problemas da tecnologia levou os pesquisadores do PIPGE a adotarem uma postura de não explorar criticamente o objeto, uma ação que, embora costumeira entre os pesquisadores do Programa, se revelou também uma tática de convencimento. Ignorando os problemas ou as polêmicas que envolvem a tecnologia, ou mesmo limitando-se a apresentá-los em alguma parte do texto, são logo esquecidos, ou seja, se valem da possibilidade de passar em branco estes pontos que poderiam enfraquecer o argumento. Pois, podemos encontrar em um resumo de 1998 a seguinte afirmação "[...] tecnologias mais eficientes precisam ser introduzidas no setor industrial brasileiro, visando incrementar a utilização da biomassa de uma forma mais eficiente $[. .$.$] " o que poderia indicar que haveria uma tecnologia, para geração de$ eletricidade a partir da biomassa, que necessitaria de um desenvolvimento adequado, aumentando a eficiência do processo, porém logo em seguida, o texto muda de foco e passou a crítica novamente ao setor elétrico brasileiro "[...] o que também irá contribuir para reduzir as dificuldades existentes no setor elétrico brasileiro garantindo o suprimento de eletricidade. "209 As possíveis deficiências da tecnologia que buscam

\footnotetext{
209 “[...] Such more efficient Technologies need to be introduced in Brazilian industrial sector aiming to improve biomass utilization in a more efficient way [...] what will also contribute to reduce existing difficulties in Brazilian electric sector to guarantee electricity supply." COELHO, Suani T. et al.
} 
inserir no contexto energético são utilizadas não para avaliar o objeto em questão, mas para direcionar os leitores para aquilo que estaria interrompendo o andamento da pesquisa ou sua aplicação. Portanto, os pesquisadores enquadram as possíveis controvérsias como se fossem um fato corriqueiro no cotidiano do pesquisador e seu objeto.

Determinar o vocabulário ou prevendo as objeções não são os únicos meios que os autores utilizam para determinar seu público e a interpretação deste sobre seus argumentos. Os leitores podem também ser levados a considerar o que antes era um problema do objeto de análise como um de seus principais argumentos. Se a tecnologia da biomassa era deficitária em 1998, dois anos depois, em 2000, em um artigo na Revista Agroanalysis da Fundação Getúlio Vargas, cuja edição destacava a "emancipação do setor sucroalcooleiro", o pesquisador Suani Coelho do PIPGE enfatiza que:

O combustível (bagaço de cana) e os equipamentos utilizados são nacionais, contribuindo para a independência energética e para a dinamização do setor de máquinas e equipamentos, com o subseqüente crescimento na arrecadação de impostos. E, além disso, há a vantagem da geração de empregos, não apenas na zona rural, mas também nos setores indiretamente afetados. ${ }^{210}$

Se o problema era a tecnologia disponível em território nacional para a cogeração de eletricidade, neste momento esta se torna a resposta que o setor necessita para a sua "emancipação". Adequando o discurso das ciências aos seus principais interessados, o pesquisador procura convencer o setor sucroalcooleiro de que o processo e a tecnologia disponíveis são viáveis e podem inclusive gerar empregos direta e indiretamente.

Brazilian policy for greenhouse gas mitigation: the national reference center on biomass. In: II EETIC Teams meeting, s/e, 1998. p. 1.

${ }^{210}$ COELHO, Suani T. Questão de bom senso. In: Agroanalysis. Rio de Janeiro: Fundação Getulio Vargas, 2000. p. 32. 
O mesmo ocorrendo no caso da energia solar fotovoltaica. Os custos da tecnologia, sua manutenção e os questionamentos sobre a confiabilidade na geração de energia por este equipamento são focados em alguns momentos nos textos do Programa. Em sua maioria, quando abordados, acabam por serem sobrepostos por uma gama de elementos positivos, especialmente as vantagens ambientais da energia solar. Embora encontramos referências, mesmo no ano 2000, a suas limitações enquanto tecnologia, como já citado anteriormente. ${ }^{211}$ Tais limitações, que estavam relacionadas aos custos econômicos, ao clima e também ao armazenamento da energia gerada, facilmente podiam ser sobrepujados por suas vantagens ambientais, que iam desde considerar a fonte fotovoltaica enquanto integrante da lista de "[...] recursos energéticos renováveis e não agressores ao meio ambiente [...]" 212 até mesmo em 2002. Quase dez anos antes, em 1993, quando ainda estavam tentando inserir a fonte energética no contexto nacional, por exemplo, Maria Julita Ferreira escreve que:

Atualmente, em função das preocupações mundiais com as condições de habitabilidade do planeta, especialmente para o futuro, a geração fotovoltaica de energia solar tem sido lembrada pelo seu caráter não poluente. É fato que a durante o processo de geração de energia por conversão fotovoltaica não ocorre praticamente nenhuma agressão ambiental no entorno das instalações, e o risco de acidentes é mínimo, o que não se pode dizer de nenhuma outra forma de geração de energia (exceção feita talvez à geração eólica). ${ }^{213}$

O discurso apresentando leva o leitor a compreender que a fonte solar de energia deveria ser utilizada por ser composta de elementos ambientalmente corretos, permitindo que este tenha a sensação de que a tecnologia em nenhum momento cause algum tipo de prejuízo ao meio ambiente. Porém, a questão que fica oculta, ou pelo menos que não pode ser encontrada facilmente nos textos do Programa, não é quanto à

\footnotetext{
${ }^{211}$ Vide citação Trigoso, nota 122.

${ }^{212}$ OLIVEIRA, Sérgio Henrique Ferreira de. Op. cit. 2002. p . 22.

${ }^{213}$ FERREIRA, Maria Julita Guerra. Op. cit. 1993. p. 83.
} 
presença de processos poluidores no ato de geração de energia, mas sim durante o processo de fabricação dos equipamentos.

O físico Sergio Oliveira, em relação à qualidade ambiental da energia solar, escreve na sua tese que: "A tecnologia fotovoltaica de geração de eletricidade é uma fonte renovável de energia que, durante o processo de geração elétrica não possui qualquer tipo de dano ao meio ambiente [...]", sem, no entanto, fazer qualquer referência ao momento anterior, durante a confecção dos equipamentos que compõem o sistema. Porém, ainda em sua tese, admite, sem no entanto prosseguir no assunto, que:

Em relação às questões ambientais, pode-se afirmar que a tecnologia solar fotovoltaica não gera qualquer tipo de efluentes sólidos, líquidos ou gasosos durante a produção da eletricidade. Também não emite ruídos nem utiliza recursos naturais esgotáveis. No entanto, há dois tópicos que ainda permanecem em discussão: a emissão de poluentes e gastos energéticos durante o processo de fabricação dos módulos e as suas possibilidades de reciclagem depois de terminada sua vida útil. ${ }^{214}$

Dois tópicos em aberto, mas que aparentemente não estariam arrolados na lista das discussões principais sobre a energia solar. O importante para os autores do PIPGE era ressaltar que, em relação ao contexto, a tecnologia funcionava, era útil, tinha um público que já havia demonstrado a sua viabilidade. Se as questões ambientais ou qualquer outro tipo de problema fossem apresentados, estes não passariam de debates menores, ou então, sem uma definição nos meios acadêmicos, quanto a sua interferência na aplicação da energia.

O discurso perpassa o contexto, montando uma realidade científica que exclui e inclui os elementos que os cientistas escolhem para seus enunciados. Os argumentos contribuem no sentido a dotar o momento histórico de significados que são construídos pelos autores. Ao escolherem a larga ou baixa escala, definirem seus leitores e suas

\footnotetext{
${ }^{214}$ OLIVEIRA, Sérgio Henrique Ferreira. Op. cit. 2002. p. 117-118.
} 
hierarquias, assim como na descrição do estado da arte de suas tecnologias e por vezes na falta da crítica ao seu objeto e mesmo ao seu enunciado, os pesquisadores do PIPGE atuam no elemento discursivo para interferir no contexto em que estão situados. Mas o contrário também ocorreu, ou seja, quando o discurso foi modificado pela conjuntura, com alterações no setor energético, as crises, que levaram os cientistas do Programa a opinarem e introduzirem novos elementos aos seus enunciados, procuravam se adaptar a realidade cientifica e política que se apresentava para eles.

O mote do capítulo seguinte será o de compreender o conjunto de idéias que moveriam este tipo de pesquisa científica, principalmente em relação às energias alternativas. O problema a seguir indica elementos de uso entre os cientistas preocupados com a área de energia e os do PIPGE não se esquivam deles, enquanto força que promoveria e tornaria fundamentais seus trabalhos para as sociedades. 
"Sim! Concerto elétrico! E que instrumentos! Graças a uma técnica húngara, duzentos pianos intercomunicados entre si por meio de uma corrente elétrica tocavam juntos sob a mão de um único artista! Um piano com a força de duzentos pianos." (Júlio Verne, 1863) 


\section{CAPÍTULO 3 - CORNUCÓPIA ENERGÉTICA: HISTÓRIA, PROGRESSO E DESENVOLVIMENTO SUSTENTÁVEL.}

No capítulo anterior tratei das características gerais do discurso do PIPGE em relação às energias alternativas pesquisadas no âmbito do Programa. Agora exponho sobre características da produção científica que, embora apareçam na documentação de forma escassa e por vezes sub-repticiamente, fizeram parte do conjunto de idéias que orientavam a pesquisa. Idéias que muitas vezes serviram de fundamento para os argumentos e enunciados dos pesquisadores em seus textos.

Assim, o capítulo se divide em duas partes: inicialmente trato de duas questões, a primeira sobre a defesa, pelos pesquisadores, da existência de um passado para a biomassa de cana de açúcar, como também a idéia de progresso tecnológico no caso da energia solar, servindo como características que teriam a função de justificar as pesquisas na década de 1990. Na segunda parte, fiz a análise do conceito de sustentabilidade, enquanto fundamental para os enunciados do Programa no sentido a adaptar o discurso sobre as energias alternativas aos anseios sociais e políticos do período.

Isto posto, além dos pesquisadores do Programa e sua literatura científica, fez-se necessário a busca por outras obras, e, para tanto, autores que se dedicaram aos temas durante os períodos abordados aqui. Em sua maioria são cientistas estrangeiros, dos Estados Unidos e Europa, que apresentaram um apelo ambiental e uma crítica ao modo de vida dos países ocidentais. Esta presença se justifica no sentido de relacionar as argumentações utilizadas pelo PIPGE dentro de uma ótica geral de enunciados sobre o tema. 


\section{História e progresso: o passado da biomassa e o desenvolvimento da energia solar.}

No ano de 1973, os países exportadores de petróleo, associados sob a sigla OPEP (Organização dos Países Exportadores de Petróleo), decidiram diminuir a extração, gerando um abalo no comércio mundial do produto, tendo como intento forçar o aumento dos preços dos barris, que estavam estagnados na faixa de 2 dólares desde o final da Segunda Guerra Mundial. A iniciativa apresentou os resultados esperados, havendo o aumento significativo: num primeiro momento para 12 dólares e meses mais tarde atingindo a marca de 30 dólares o barril. Esse acontecimento, taxado de "choque do petróleo", deixou marcas profundas na economia mundial e também nas questões estruturais, a energia no caso, das nações dependentes da importação de petróleo para o funcionamento de suas sociedades.

O Brasil procurou escapar deste acontecimento de 1973 ao fazer uso de um combustível encontrado em grande parte do Estado de São Paulo: o álcool da cana-deaçúcar, produto que antes privilegiava somente o mercado de açúcar e que passava por um período de crise. O setor canavieiro foi o principal agente para a produção do álcool, recebendo incentivos e subsídios do governo federal a partir de 1975, para fabricação em larga escala do combustível, ao mesmo tempo que a indústria automobilística nacional ia adaptando os motores de seus veículos para poder utilizar o álcool. Duas seriam as finalidades do produto: por um lado, seria utilizado com incremento na gasolina - o álcool anidro - e, por outro, seria diretamente empregado como combustível - o álcool hidratado. Surgia então uma solução que, apesar de não substituir inteiramente a necessidade do petróleo, proporcionou o alívio para o país e o Estado de São Paulo em meio à crise internacional causada pelo "choque". 
O governo brasileiro lança, no ano de 1975, o Programa Nacional do Álcool (Proálcool), com investimentos para a intensificação de culturas agrícolas, além de financiar usinas para a fabricação do álcool. Logo no início, o programa acabou se destinando para a cana-de-açúcar, que, por ter grandes áreas de cultivo no país, demonstrava possibilitar a resposta rápida à crise energética no setor de combustíveis. Deixam-se de lado outras matérias primas que poderiam gerar álcool, como a mandioca, batata e babaçu.

Nos anos que se seguiram ao início do Proálcool, entre 1975 e 1979, o Governo Militar que administrava o Brasil apresentava um discurso de incentivo e exaltação do programa. Este denotava a capacidade brasileira de solucionar a crise do petróleo, estimular a geração de empregos (os bóias-frias) e também a redistribuição de renda com o aumento dos trabalhadores empregados e de terras cultivadas, como sendo as principais características que marcariam o sucesso do programa do álcool no país. No entanto, como afirma Valdir Pietre em artigo que analisa a questão jurídica do Proálcool:

\footnotetext{
Apesar de intenções tão salutares, na prática, o Proálcool vem contribuindo para concentrar ainda mais a propriedade da terra, sem garantir novos empregos, sem melhorar a distribuição de renda interna e sem reduzir as disparidades regionais $\left[\ldots . .{ }^{215}\right.$
}

Isto se agravaria pelo fato de a produção do álcool ter sido destinada unicamente à cana-de-açúcar, monopólio de usineiros e latifundiários produtores de açúcar, concentrado em sua maioria no estado de São Paulo, que além de tudo utilizavam uma colheita mecanizada, que não faria uso da mão-de-obra. ${ }^{216}$

\footnotetext{
${ }^{215}$ PIETRE, Valdir. Proálcool: legislação, ecologia e questão social. In: Encontros com a Civilização Brasileira. V. 26, 1980. p. 69.

${ }^{216}$ Idem.
} 
A cana foi a privilegiada e isto se justificava pelos baixos preços internacionais do açúcar, causando prejuízos na lavoura e nas usinas; portanto, a solução era investir nesta produção ao mesmo tempo em que era fabricado o álcool. Apesar do intuito de redistribuição de renda, assim como previsto pelo programa, a maior parte das usinas foram destinadas ao estado de São Paulo, que já contava com uma safra significativa de cana; do total de 243 destilarias aprovadas em 1979, 93 eram destinadas ao estado. ${ }^{217}$

O álcool não era um combustível desconhecido no país, sendo utilizado de forma mais intensa durante a II Guerra Mundial, no período 1939 a 1945, quando a produção de petróleo estava sendo destinada aos esforços de guerra. Como relata João B. Peixoto, durante este período:

[...] em todo o Nordeste o combustível usado nos veículos era o álcool. Naquela região o exército usa 'USGA' (sigla do álcool produzido pela Usina Serra Grande de Alagoas) em automóveis e caminhões, como motores sumariamente adaptados. ${ }^{218}$

No entanto, o produto foi colocado de lado, quando ao fim da guerra os preços do petróleo para a importação foram fixados em níveis baixos, sendo mais atrativo que a continuidade do álcool para a utilização nos meios de transporte. Permanecera somente a produção em menor escala como aditivo da gasolina e como matéria-prima industrial.

A tecnologia e a utilização do combustível enquanto um recurso nacional somente se tornariam necessárias novamente na década de 1970, quando a estrutura do Proálcool foi montada sobre a criação de um parque de produção, no qual seria produzido o álcool combustível a partir da cana-de-açúcar. Foram construídas usinas e anexos em unidades açucareiras, o que possibilitou a fabricação tanto do açúcar quanto

\footnotetext{
${ }^{217}$ Cf. MELO, Fernando Homem de \& FONSECA, Eduardo Giannetti da. Proálcool, energia e transportes. São Paulo: Pioneira; FIPE, 1981; PEIXOTO, João B. O desafio da crise energética. Rio de Janeiro: CAPEMI, 1981; CALABI, André Sandro et. al. A energia e a economia brasileira: interações econômicas e institucionais no desenvolvimento do setor energético no Brasil. São Paulo: Pioneira: Fundação Instituto de Pesquisas Econômicas, 1983.

${ }^{218}$ PEIXOTO João B. Op. cit. p. 118.
} 
do álcool. O Proálcool acelerou suas atividades somente em 1979, com a produção de 3,3 bilhões de litros de álcool. Tal produção inicial conduzia o governo a certo clima otimista quanto aos resultados do programa, chegando a estipular a meta de 10,7 bilhões de litros de álcool para o ano de 1985. Porém, a partir de 1986, o consumo do produto no mercado interno começou a declinar, representando o fim do otimismo e o começo de um período de queda na produção do álcool. Segundo Calabi e outros, a administração do programa ficaria por conta da Comissão Nacional do Álcool (CENAL), porém tanto este órgão quanto o Instituto do Açúcar e do Álcool definiam a política nacional, gerando uma extrema burocratização nas decisões sobre o assunto. ${ }^{219}$

O estímulo à produção viria dos créditos subsidiados pelo governo federal, com recursos maiores e juros menores do que encontrados nos programas regulares de crédito rural. ${ }^{220}$ Estes procedimentos de controle da produção e do financiamento, que levavam a uma demasiada centralização de todo o processo, eram agravados pela

[...] excessiva intervenção governamental, uma política de preços e crédito incompatível com o desenvolvimento das empresas alcooleiras [...]" levando a um "[...] círculo vicioso de dependência do governo, inclusive no que diz respeito às inovações tecnológicas $\left[\ldots . . .{ }^{221}\right.$

A bibliografia revela que a intervenção Estatal, marca do Proálcool na década de 1970, para a continuidade e manutenção do Proálcool teria deixado o programa estagnado, não havendo a concorrência direta entre os produtores, já que toda a safra era comprada, assim como o plantio subsidiado pelo governo. Havia, no entanto, a busca por novas áreas de plantio, criando latifúndios monocultores de cana-de-açúcar, além da utilização de mão-de-obra barata, os bóias-frias, o que aumentava o lucro dos usineiros.

\footnotetext{
${ }^{219}$ CALABI et al. Op. cit.

${ }^{220}$ MELO, Fernando Homem de \& FONSECA, Eduardo Giannetti da. Proálcool, energia e transportes. São Paulo: Pioneira; FIPE, 1981.

${ }^{221}$ CALABI et al. Op. cit. pp. 175-176.
} 
A análise dos textos mostrou que tais questões estiveram presentes nos argumentos dos pesquisadores do PIPGE, durante toda a década de 1990, indo até 2002, quando estes buscavam traçar justificativas para a pesquisa que desenvolviam, fundando suas bases no Proálcool, ou mesmo tratando o objeto pesquisado como uma peça-chave para a continuidade da produção do combustível em território nacional.

O Proálcool foi alvo das argumentações do PIPGE nos trabalhos sobre biomassa. Os pesquisadores utilizavam a ligação do bagaço de cana com a produção de álcool combustível, numa ligação histórica, servindo de elo para fortalecer a postura que estes adotavam e até mesmo para o próprio objeto pesquisado.

A relação histórica com o álcool e com o "choque do petróleo" que os pesquisadores buscam inserir nos textos pode ser considerada como um elemento da literatura que produziram. Inclusive, historicizando o objeto, trazem a evolução, desenvolvimento e demais melhorias na tecnologia e em sua aplicação ao longo de cenários de outros períodos. A lembrança do Programa do Álcool (Próalcool) foi um fator comum nos textos sobre biomassa dentro do PIPGE.

Desde as primeiras dissertações até o final do período recortado em 2002, a utilização do Próalcool como argumento pode ser considerada presente em toda a literatura, principalmente nos textos para eventos no exterior. O motivo para o uso desse recurso talvez se devesse à proximidade entre ambos os objetos, ou seja, o setor sucroalcooleiro, produtor de açúcar e álcool a partir da cana de açúcar, que necessitava de energia elétrica e vapor para os procedimentos industriais, precisando também escoar o bagaço da cana. Além disso, a cogeração permitia reduzir os custos de seus produtos principais e, por fim, o excedente poderia ser vendido às concessionárias, gerando uma renda extra ao produtor de cana. 
Como foi dito em 1996, contando com a participação do então secretário do Estado de São Paulo de Energia, os pesquisadores do PIPGE, David Zylbersztajn e Suani Coelho: “[...] Um programa de cogeração em larga escala poderá contribuir para reduzir os custos de produção do etanol devido à receita da venda de eletricidade." ${ }^{222}$ Pelo fato que o Próalcool estava passando por uma crise de incentivos econômicos, se tornava necessária para os pesquisadores do PIPGE a recuperação do setor sucroalcooleiro

O Programa Nacional do Álcool, Proálcool, estabelecido no Brasil em 1975, demonstrou um grande sucesso técnico. Durante os anos 1980, muitos novos veículos (cerca de 90\%) foram fabricados a álcool e a frota de álcool alcançou quase 5 milhões de veículos. Contudo, atualmente o Proálcool ainda apresenta controvérsias em relação ao ponto de vista econômico e de incentivos que são necessários. ${ }^{223}$

O que estes pesquisadores não revelam, no entanto, é que, nesta mesma década de 1980, quando o álcool estava presente na grande maioria da frota de veículos nacionais, se deu a redução da produção, comercialização e da própria frota de veículos que utilizavam o combustível, especificamente, de 1986 em diante. Eles destacam o papel do programa do álcool para o setor energético, sem revelar que este não havia ultrapassado a década em questão com os mesmos índices de aproveitamento no território nacional.

Utilizar a cogeração implicava também a recuperação das usinas de álcool, talvez sendo esta iniciativa a sua principal vantagem tecnológica, econômica, ambientai e social, tal como explicou em sua tese de 1999 a então doutoranda Suani Coelho:

\footnotetext{
222 "A large scale co-generation program could contribute to reduce ethanol production costs due to revenues from electricity sales." ZYLBERSTAJN, David e COELHO, Suani Teixeira. A preliminary analysis of mechanisms to improve biomass-origin co-generation in Brazil. IN: $9^{\text {th }}$ European Bioenergy Conference. Copenhagen/Dinamarca: Elsevier Science Ltd. Junho, 1996. p. 446.

223 "The National Alcohol Program, Proalcool, established in Brazil in 1975, has achieved a great technical sucess. During the 80 's, most of the new vehicles (around 90\%) were alcohol fueled and alcohol fleet reached almost 5 million vehicles. However, Proalcool still presents controversies nowadays under an economic point of view and incentives are needed." Idem. p. 446
} 
Considerando os conhecidos benefícios sociais, ambientais e estratégicos do Programa Nacional do Álcool, a cogeração de eletricidade no setor sucro-alcooleiro poderia ser um mecanismo para, em conjunto com as outras medidas em estudo pelo Governo Federal colaborar para evitar a extinção do Programa Nacional do Álcool. ${ }^{224}$

Recorre à historicização do objeto para compor uma conjuntura de utilização do mesmo, ressaltando seus avanços tecnológicos e científicos. Isto se torna representativo do tipo de historicização que os pesquisadores utilizam para com as fontes alternativas, criando potencialidades que só poderiam ser comprovadas se fossem baseadas no passado que tais tecnologias teriam.

[...] Se a história não tem outro significado a não ser concretizar uma potencialidade - isto é, efetivar o que já existia na causa -, então, independentemente da sarabanda de associações que ocorrerem, nada, ou pelo menos nenhuma coisa nova, acontecerá jamais, porquanto o efeito já estava oculto na causa como potencial [...]. ${ }^{225}$

Haveria supostamente uma historicidade inerente aos objetos pesquisados para a energia solar ou para a biomassa da cana. O passado como representante de uma espécie de raiz científica ou tecnológica dos objetos permite torná-los fatos sociais antes mesmo de serem fatos científicos, ou como Latour destaca "[...] A causalidade vem depois dos eventos, não antes [...].",226

Para a biomassa, se sua vinculação com o Proálcool não fosse suficiente para estimular e exemplificar as vantagens da cogeração, a pesquisadora do PIPGE Suani Coelho, em 1992, vai em busca de recuperar as formas de uso no passado da biomassa, partindo do que seria um processo evolutivo desde a Revolução Industrial " [...] As primeiras experiências com gaseificação de carvão datam de 200 anos atrás, na Inglaterra, com significativo desenvolvimento durante a Segunda Guerra Mundial

${ }^{224}$ COELHO, Suani T. Mecanismos para implementação da cogeração de eletricidade a partir de biomassa. Um modelo para o Estado de São Paulo. São Paulo: PIPGE (Tese de Doutorado), 1999. p. 30.

${ }^{225}$ LATOUR, Bruno. A esperança de Pandora: ensaios sobre a realidade dos estudos cientificos. Bauru: EDUSC, 2001. p. 177.

${ }^{226}$ Idem. p.177 (grifo do autor). 
[...]." até recentemente no país, quando "[...] na década de 1980, vários fabricantes de gaseificadores deste tipo existiam, em particular no Brasil, com carvão vegetal, e nas Filipinas, com madeira [...]" chegando à atualidade considerando que houve o domínio humano sobre a técnica de gaseificação da biomassa ${ }^{227}$, inclusive se contradizendo, pois a mesma pesquisadora afirma páginas depois que não havia dados suficientes sobre o processo de gaseificação da biomassa de cana, aguardando para um futuro próximo essas informações. ${ }^{228} \mathrm{Ou}$ então fornecendo informações que ressaltam o progresso no conhecimento científico de determinado processo:

A partir da década de 1960, o processo de digestão anaeróbica passou a ser encarado de maneira mais científica, havendo então, progresso quanto à compreensão dos fundamentos envolvidos, controle e operação dos mesmos e adequação dos equipamentos utilizados. ${ }^{229}$

Aliás, utilizar o conceito de progresso científico foi uma questão de destaque nas teses e dissertação sobre energia solar ao longo de todo o período abordado, sendo que apareciam em trabalhos que tinham como mote a análise da fonte e sua introdução no contexto energético nacional.

Esta vinculação da tecnologia em energia solar com os progressos científicos demarca outro tema relacionado ao "choque do petróleo" de 1973. Além de toda uma literatura específica que surgiu nos EUA nos anos posteriores a este acontecimento, tal como os já referidos trabalhos de Barry Commoner ${ }^{230}$, os pesquisadores do PIPGE retomam esta relação, trazendo nos textos a perspectiva de um futuro em que a tecnologia atingiria níveis adequados de eficiência.

\footnotetext{
${ }^{227}$ COELHO, SUANI T. Op. cit. 1992. p. 67.

${ }^{228}$ Cf. COELHO, Suani T. Op. cit. 1999.

${ }^{229}$ ALMANÇA, Reinaldo Alves. Avaliação do uso da vinhaça da cana-de-açúcar na geração de energia elétrica (Estudo de Caso). São Paulo: PIPGE (Dissertação de Mestrado), 1994. p. 34.

${ }^{230}$ COMMONER, Barry. Op. cit. 1986.
} 
A leitura dos textos mostrou que os pesquisadores do PIPGE defendiam a relação da energia solar com o progresso científico, anterior mesmo ao choque do petróleo. Inclusive, quando historicizam as pesquisas, os pesquisadores da energia solar costumam ir até o século XIX para fincar as raízes do início das atividades científicas sobre a energia solar. Principalmente em relação às pesquisas de Edmond Becquerel, que em 1839 teria escrito um tratado sobre a capacidade elétrica da luz solar ao atravessar determinadas cores. Este momento foi tido como o inaugural para a energia solar por alguns pesquisadores do PIPGE e mesmo por autores da década de 1970. Provavelmente, isto parte do princípio de que, resgatando as origens da cientificidade da tecnologia ou mesmo do objeto o tornaria presente na sociedade, diminuindo a possível rejeição caso fosse compreendida como uma novidade, e talvez não confiável. A pesquisadora Maria Julita Guerra Ferreira, em sua dissertação de 1993, busca Becquerel, e inclusive coloca no apêndice de seu trabalho, uma cópia do tratado do cientista francês.

\footnotetext{
Em 1839 foi observado pela primeira vez que a simples incidência da luz pode gerar uma tensão elétrica em uma estrutura de materiais apropriados. Em1876 foi concebido o primeiro aparato fotovoltaico advindo dos estudos das estruturas de estado sólido, e apenas em 1956 iniciou-se a produção industrial. Embora sejam eventos relativamente recentes, o desenvolvimento de tais artefatos para o uso da energia solar é de inegável importância. ${ }^{231}$
}

Se a importância do estabelecimento de uma tecnologia poderia ser definida em um tempo relativamente recente, a justificativa para a pesquisa e desenvolvimento da mesma deveria ter um momento significativo.

\footnotetext{
${ }^{231}$ FERREIRA, Maria Julita Guerra. Op. cit. 1993. p. 37.
} 
Novamente teremos o choque de 1973 como marco para os incentivos de cientistas e ciências na busca por tornar o que tinha um desenvolvimento recente em algo para ser utilizado como fonte energética principal.

Neste sentindo, no PIPGE os pesquisadores traçavam a cronologia dos acontecimentos que acreditavam marcar o desenvolvimento da tecnologia: "Os eventoschave no desenvolvimento dos equipamentos de conversão da energia solar fotovoltaica podem ser visualizados através de uma representação logarítimica no tempo [...]"232, não apenas seriando os eventos, mas também equacionando as informações para chegar à conclusão de que haveria uma evolução no conhecimento sobre o objeto no decorrer de determinada duração temporal.

$\mathrm{Na}$ evolução da tecnologia, presente em diversas teses e dissertações do PIPGE, o acontecimento chave funciona como elemento de argumentação que serviu como impulsionador para que a tecnologia tivesse sua caminhada rumo ao auge. E até quase trinta anos depois, em 2001, na tese de Paulo Marcos Noronha Serpa, podemos encontrar tanto a seriação do tempo, quanto o marco temporal em questão:

A crise do petróleo provocou o ressurgimento da produção de células
solares, nos fins dos anos 70 . Nos anos 80 , a pesquisa dedicou
interesse no desenvolvimento do silício amorfo, devido ao seu baixo
custo de produção; nos EUA, foram desenvolvidas várias aplicações,
como a produção de módulos fotovoltaicos para utilização em
sistemas. A partir de então, a tecnologia fotovoltaica desenvolveu-se
rapidamente.

Entendo que, se houve um desenvolvimento rápido, isto se deu pela dinâmica da pesquisa, impulsionada principalmente nos EUA, espaço no qual a energia solar teve uma divulgação maior pela mídia e por cientistas como Barry Commoner. Assim, a rapidez na evolução tecnológica teria sido fruto, segundo Serpa, da crise, pois esta “[...]

\footnotetext{
${ }^{232}$ Idem. p. 37.

${ }^{233}$ SERPA, Paulo Marcos Noronha. Eletrificação fotovoltaica em comunidades caiçaras e seus impactos socioculturais. São Paulo: PIPGE (Tese de Doutorado), 2001. p. 47.
} 
veio conferir à tecnologia fotovoltaica um papel alternativo de suprimento parcial das necessidades energéticas globais [...].", porém, o mais revelador seria que “[...] os grandes investimentos financeiros para o desenvolvimento dessa tecnologia vieram das grandes companhias de petróleo."234

Cabem aqui algumas indagações a respeito dessa citação, pois se o financiamento para que a energia solar se tornasse uma realidade na matriz energética era proveniente das empresas petroleiras, principais interessadas na manutenção das características dessa matriz, essas empresas teriam a capacidade de controlar as pesquisas? Teria sido por isso que a tecnologia não alcançou a "evolução" a ponto de se tornar a solução para os problemas energéticos mundiais? O pesquisador Paulo Marcos N. Serpa não trata desse assunto, encerra a questão neste ponto, direcionando seu texto para outros argumentos.

Nem mesmo Maria Julita Guerra Ferreira ou os demais pesquisadores em energia solar, como Federico Morante Trigoso e Sergio Henrique Oliveira, tomaram este rumo; apenas deixaram para o futuro a crença de que " $O$ desenvolvimento das pesquisas das células de filmes finos, e sua produção em escala industrial, é o próximo passo, e talvez o que vá definir as novas linhas de geração elétrica no mundo, para o próximo milênio." ${ }^{235}$

A crença da maioria desses pesquisadores do PIPGE da linha de pesquisa sobre energias alternativas foi em relação aos avanços no conhecimento e na tecnologia, o que teria funcionado enquanto motivação na continuidade as suas pesquisas.

No caso do PIPGE, esta crença os leva a assumir que as barreiras tecnológicas, econômicas, políticas que impedem a introdução dessas fontes na matriz seriam superadas com a Pesquisa e o Desenvolvimento da biomassa e a energia solar

\footnotetext{
${ }^{234}$ Idem. p. 47.

${ }^{235}$ FERREIRA, Maria Julita Guerra. Op. cit. 1993. p. 37.
} 
fotovoltaica. "[...] há a necessidade de desenvolvimento de um numero maior de projetos de demonstração [...]" observa Suani Coelho em sua tese sobre a biomassa no ano de 1999, pois tais exemplos poderiam incentivar o setor sucro-alcooleiro a implantar a cogeração em suas usinas e também "[...] irão permitir a introdução (a curto prazo) das tecnologias atualmente em desenvolvimento em outros países.",236

Em 2002, o pesquisador do PIPGE Sergio Oliveira escreve sobre o progresso de todas as fontes alternativas de energia, explicando que

[...] Com o progresso da ciência, novas tecnologias de geração passam a compor o rol de opções para o setor e a competir com as tecnologias tradicionais, procurando espaço para entrar no mercado de geração de eletricidade. Esses recentes desenvolvimentos tecnológicos, como as micro-turbinas, celular de combustível, energia solar fotovoltaica e de cogeradores [...] essas tecnologias passam progressivamente a ser competitivas e a viabilizar a geração distribuída de energia. ${ }^{237}$

Dessa maneira, se houvesse barreiras ou se elas estivessem presentes durante o processo de aplicação das fontes energéticas, elas seriam superadas pelo progresso científico, assim como teriam sido superadas ao longo do processo histórico de desenvolvimento dessas energias alternativas.

Tais fontes energéticas teriam, para os pesquisadores do Programa, a capacidade de se superar historicamente, avançando num grau de desenvolvimento que teria por fim a perfeita adequação aos requerimentos que as sociedades delas pediam. Se estas fontes alternativas, tidas como tecnologias do futuro desde 1972 durante a Conferência da ONU em Estocolmo, apresentaram durante a década de 1970 até o final de nosso período, em 2002, falhas em suas execuções ou então um lento progresso, isso teria sido resultado de problemas externos à ciência; em nenhum momento os pesquisadores

\footnotetext{
${ }^{236}$ COELHO, Suani T. Op. cit. 1999. p. 71.

${ }^{237}$ OLIVEIRA, Sérgio Henrique Ferreira de. Geração distribuída de eletricidade: inserção de edificações fotovoltaicas conectadas à rede no Estado de São Paulo. São Paulo: PIPGE (Tese de Doutorado), 2002. p. 21.
} 
cogitam em sua literatura a perspectiva de terem atingido os limites do conhecimento sobre a tecnologia.

Fora do PIPGE também teremos estas argumentações. Autores externos ao Programa da USP traziam em seus textos questões sobre o progresso tecnológico atingido e as perspectivas futuras quanto aos desenvolvimentos a serem alcançados. Um olhar sobre as bibliografias produzidas fora do PIPGE pode auxiliar na compreensão deste ponto como uma questão ampla, que foi discutida em vários âmbitos e por vários atores.

Entendo que as cicatrizes deixadas pela década de 1970, pelo choque do petróleo, são marcas que perduram até a atualidade, sempre como uma preocupação que extrapola os meios econômicos, atingindo diretamente aos cientistas, pois estes enquanto "responsáveis" pela solução energética, tão necessária ao mundo moderno e contemporâneo, ainda jogam para o futuro a resolução dos problemas.

Tais cicatrizes foram aprofundadas pelo movimento ambientalista iniciado nos anos 1960, sendo durante a década seguinte atuantes no que diz respeito a crítica das fontes energéticas poluidoras. Ao longo de 1980 e 1990, apresenta um papel ao mesmo tempo de contraponto às medidas de governos quanto de colaboradores nas tomadas de decisões por orgãos supranacionais, como a ONU. Parte desta colocação do movimento ambientalista pode ser devido aos grupos que dele faziam e ainda fazem parte: membros da sociedade civil, políticos, economistas e cientistas. Para compreender a postura ambiental/científica que adotaram a partir das marcas deixadas pelo "choque do petróleo" de 1973 e os discursos sobre as alternativas que proferiram irá nos ligar ao próximo item "desenvolvimento sustentável" por conta das conseqüências de suas colocações. 
Em praticamente qualquer tipo de trabalho das últimas décadas para cá que tenha como tema meio ambiente, poderemos encontrar referências, discursos e análises sobre energia. Autores com formação científica que adentraram no "mundo ambientalista" da década de 1970 e 1980 invariavelmente, em seus textos, não deixam de empreender um capítulo ou parágrafo que seja sobre o tema, principalmente fazendo alusões às energias alternativas. $\mathrm{O}$ resultado imediato foi conectar energia por vários fios na égide ambientalista, conseqüentemente orientando as argumentações a respeito das fontes renováveis pelo sentido de ecológicas.

Tais questões foram provenientes de acontecimentos: o repetidamente referido “choque do petróleo", as reuniões da ONU (1972 e por toda a década de 1980), acidentes nucleares (Chernobyl e Three Mile Island) ${ }^{238}$; as publicações: Barry Commoner "Energias alternativas", Enzo Tiezzi "Tempos históricos, tempos biológicos", o "Relatório Brundtland", as publicações do Worldwatch Institute durante a década de $1990 .^{239}$

Os conceitos: desenvolvimento sustentável, renovabilidade, ecologicamente limpo, sustentabilidade e tudo o mais que vier no pacote ambiental (ou seria pacote político-ambiental?) acabaram sendo englobados pelo discurso de governos, políticos, economistas, de ambos os lados, direita ou esquerda.

O que podemos tirar disto é que houve a adequação em vários sentidos do conceito de energias alternativas, servindo de base para um punhado de causas, e sugiro

\footnotetext{
${ }^{238}$ Three Mile Island, nome dado a uma usina localizada na ilha homônima, foi um acidente que ocorreu no território dos EUA em 1980, sem grandes proporções, ao contrário de Chernobyl em 1986, na então URSS, cuja rachadura no núcleo do reator causou mortes e doenças em milhares de pessoas, além do isolamento de toda uma região na atual Ucrânia.

${ }^{239}$ COMMONER, Barry. Energias Alternativas. Rio de Janeiro: Editora Record, 1986; TIEZZI, Enzo. Tempos históricos, tempos biológicos. São Paulo: Nobel, 1988; COMISSÃO MUNDIAL SOBRE MEIO AMBIENTE E DESENVOLVIMENTO. Nosso futuro comum. Rio de Janeiro: Editora da Fundação Getulio Vargas, 1988; BROWN, Lester (org.). Worldwatch Institute. Qualidade de vida: salve o planeta! São Paulo: Globo, 1993; GOLDEMBERG, José \& VILLANUEVA, Luz D. Energia, meio ambiente e desenvolvimento. São Paulo: EDUSP, 2003; ROSA, Luiz Pinguelli. O apagão: por que veio? Como sair dele? Rio de Janeiro: REVAN, 2001.
} 
que tudo isto teria sido originado pelas cicatrizes deixadas no ano de 1973. Anteriormente, a literatura sobre as fontes alternativas de energia, quaisquer que fossem estas, pode ser considerada como inexistente. Talvez um manual técnico ou textos afins sobre energia solar, utilizada durante a "corrida espacial" no período de 1950 até 1960, como geradora elétrica para satélites e demais tecnologias espaciais, ou então para telefonia, como fonte em pontos isolados da rede elétrica. No mais, teremos a utilização, como exposta acima, do álcool pelo Brasil durante a Segunda Guerra Mundial. No entanto, nenhuma incidência encontrada para as demais fontes energéticas. ${ }^{240}$

O medo gerado pelo fim da principal matéria-prima utilizada para o abastecimento energético no planeta, os combustíveis fósseis, levou à idealização das energias alternativas enquanto o futuro da humanidade. "Esta é a onda do futuro[...]" afirma o físico professor do PIPGE José Goldemberg em artigo para O Estado de S. Paulo em outubro de 2000, destacando que: “[...] os países mais avançados estão investindo pesadamente no desenvolvimento de 'energias renováveis', que são alternativas viáveis às 'energias fósseis' que acabaram por se exaurir [...]."241

O contingente de informações a respeito das fontes alternativas destaca o seu papel como produto renovável, encontrado em grande quantidade e variedade na natureza, contrapondo-se aos adjetivos: esgotável e poluente, das fontes fósseis. Numa entrevista para um jornal em 2003, José Walter Bautista Vidal, um dos responsáveis pela implantação do Próalcool em 1975, afirma o seguinte: “O Brasil tem condições de produzir oito milhões de barris de óleo diesel de dendê da Amazônia, que é natural,

\footnotetext{
${ }^{240}$ Além, evidentemente, do uso da lenha considerada como biomassa pelas sociedades anteriores à era industrial. Porém, os trabalhos a respeito são atuais. Cf. BARTOLETTO, Silvana. L'approvvigionamento energético della citá di Napoli tra XIX e XX secolo. In: ZILLI, Ilana (Org.) La natura e la cittá per uma storia ambientale di Napoli fra '800 e '900. Napoli: Edizioni Scientifiche Italiane, 2004. pp. 139-175.

${ }^{241}$ GOLDEMBERG, José. O papel das energias renováveis. Jornal O Estado de S. Paulo, 31/10/2000. p.
} A2. 
limpo e mais eficiente que o combustível fóssil." ${ }^{242}$ Ressaltando tanto a grande capacidade de produzir energia, no caso o óleo diesel de dendê, e sua vantagem ao diesel do petróleo, que seria menos eficiente, poluente e artificial.

$\mathrm{Na}$ literatura internacional, a crise do petróleo e a ascensão das energias alternativas estão presentes em vários estudos. Um dos destaques é Barry Commoner; em artigos para jornais, revistas e palestras nos EUA em 1975 e 1977, o autor escreveu que:

O embargo representou um forte lembrete do que deveria ter sido óbvio muito antes: que o petróleo, o gás natural, o carvão e o urânio, que representam $96 \%$ do total da energia americana, são fontes nãorenováveis que se esgotam [...] mais cedo ou mais tarde teremos de buscar alguma outra fonte renovável de energia. ${ }^{243}$

Quase todos os autores, dentro ou de fora do PIPGE, irão utilizar estes contrapontos como principal argumento para o incentivo às energias alternativas. "[...] Neste caso, se não forem encontradas soluções alternativas [...]", afirmou Commoner “[...] as ruas serão despovoadas, as luzes perderão sua potência, as residências se esfriarão, as fábricas fecharão e no campo se trabalhará com a força dos homens e animais. ${ }^{244}$ Um catastrofismo mais do que aparente, e sim destacado; para os autores de porte ambientalista deste período, décadas 1970 e 1980, tais afirmações são comuns.

A crise do petróleo teve o efeito de causar abalos estruturais nas economias mundiais e ao mesmo tempo de encontrar eco nas argumentações de ambientalistas, provocando um fortalecimento das críticas destes ao padrão de vida ocidental. Sem energia, não haveria mais mundo tal qual conheciam, mas não era qualquer fonte energética que deveria ser preferencial, deveriam aproveitar a crise petrolífera e investir no futuro energético, na ciência e tecnologia. O italiano Enzo Tiezzi, discípulo de

\footnotetext{
${ }^{242}$ VIDAL, José W. B. Folha de Londrina. 01/05/2003. p. 2.

${ }^{243}$ COMMONER, Barry. Op. cit. p. 8.

${ }^{244}$ Idem. p. 8.
} 
Commoner, resume esta equação: energias alternativas, ciência, futuro, da seguinte maneira:

\begin{abstract}
A solução para superar as crises ambiental, energética e econômica é a utilização de fontes alternativas e renováveis de energia que, além de favorecerem um modelo de desenvolvimento descentralizado, não sujeito à escassez imprevista e à inflação, levarão a uma sociedade cientificamente moderna e avançada, salvaguardando o meio ambiente. ${ }^{245}$
\end{abstract}

Todas estas argumentações e afirmações criaram certo peso sobre os ombros das ciências, dos cientistas e de seus objetos, as fontes alternativas. Trazem expectativas demasiadamente carregadas de significados para que pudessem suportar a demanda de "desenvolvimento" para tais tecnologias. Essa carga pode ser verificada ao se considerar, como o fazem acima Goldemberg, Commoner, Tiezzi, que estas são tecnologias do futuro, portanto, sempre passíveis de serem melhoradas, desenvolvidas, avançadas. Ou podemos partir da afirmação de Carlos Walter Porto-Gonçalves, sobre a relação entre ciência e meio ambiente: "O mais interessante a observar é que, a rigor, a ciência e os cientistas não podem dirimir essas dúvidas por si mesmos, até porque entre eles haverá, sempre, incerteza [...]."246 Incerteza que dentre as afirmações das ciências, e aquelas sobre as energias alternativas, ficam enfraquecidas mediante o argumento do progresso científico, segundo o qual não haveria incertezas, apenas questões colocadas em cada etapa do processo epistemológico; ou seja, as ciências sempre estarão ao lado da razão, da lógica e da verdade.

Contudo, as incertezas sobre as energias alternativas estavam presentes entre seus divulgadores. Tanto que os primeiros trabalhos de divulgação da energia solar, ainda na década de 1970, procuravam descaracterizar toda uma "mitologia" que cercava

\footnotetext{
${ }^{245}$ TIEZZI, Enzo. Op. cit. p. 92.

246 PORTO-GONÇALVES, Carlos Walter. O desafio ambiental. Rio de Janeiro: Record, 2004. p. 51 (grifo do autor).
} 
a tecnologia. Novamente recorremos a Barry Commoner, quando escreve sobre tais mitos, no contexto dos EUA, “Mas parece que estamos criando tanto mitos acerca da energia solar quanto o número de mitos existente sobre o próprio sol [...]", abordando apenas os mitos mais difundidos, inclusive em relatórios oficiais do governo dos EUA:

[...] a energia solar só é utilizável nas regiões muito ensolaradas, como o Arizona; é ineficaz durante a noite e nos dias nublados; a luz solar é muito difusa para prover as altas temperaturas necessárias à geração de energia elétrica, e outra de alta qualidade; se a energia solar fosse verdadeiramente possível e valesse a pena economicamente, as grandes empresas elétricas a teriam desenvolvido. ${ }^{247}$

Por fim, talvez seja por isso que as energias alternativas ficaram e ainda ficam para o futuro, devido às crenças populares, as desconfianças e a divulgação de incertezas sobre o funcionamento e a possibilidade de substituição em sua totalidade os combustíveis fósseis. No mesmo artigo para O Estado de S. Paulo citado anteriormente, José Goldemberg escreve

O ideal seria, pois, voltar ao passado e depender somente de energias renováveis, o que, à primeira vista, parece um sonho, por uma razão muito simples: não só a população mundial é hoje muito maior como também o consumo de energia "per capita" é muitas vezes superior ao que era no passado. ${ }^{248}$

Portanto, se houve e ainda há dificuldades em adaptar as tecnologias ao contexto em que estamos situados por conta dos caminhos escolhidos, que nos levaram à dependência do petróleo, carvão e afins, devemos esperar pelos resultados das ciências. Entretanto, fica também a dúvida: se a necessidade energética aumenta em nível global, regional e local todos os anos, por conta do estilo de vida que levamos, quando será que as ciências oferecerão o desenvolvimento adequado para que sejam substituídos os sistemas baseados nos combustíveis fósseis, que, afinal, se esgotarão? O que se tem em

\footnotetext{
${ }^{247}$ COMMONER, Barry. Op. cit. p. 43.

${ }^{248}$ GOLDEMBERG, José. Op. cit. p. A2.
} 
conta nesta dúvida é que se a justificativa de mudança de matriz energética, tendo como principal argumento a esgotabilidade das fontes principais da atualidade, não tem mais a força suficiente, nem mesmo com o auxílio do apelo ecológico, de serem poluentes, os discursos dos vários grupos envolvidos nesta corrente de pensamento passa a apostar no conceito chave para a década de 1990, no que diz respeito à relação entre: economia, política, sociedade e ecologia, que é "Desenvolvimento Sustentável”.

\section{Desenvolvimento Sustentável e energias alternativas: conceitos e práticas.}

O princípio que rege o conceito de Desenvolvimento Sustentável ou pelo menos seu significado oficial está contido no "Relatório Brundtland" de 1988. O relatório, resultante de uma série de reuniões ao redor do mundo, promovida pelas Nações Unidas e realizada principalmente em países considerados na época como "subdesenvolvidos" ou de "terceiro mundo", destacava a ligação entre o discurso econômico de crescimento industrial e a utilização dos recursos naturais, mediados por uma racionalidade ambiental.

[...] o desenvolvimento sustentável é um processo de transformação no qual a exploração dos recursos, a direção dos investimentos, a orientação do desenvolvimento tecnológico e a mudança institucional se harmonizam e reforçam o potencial presente e futuro, a fim de atender às necessidades e aspirações humanas. ${ }^{249}$

Significava que a continuidade dos processos produtivos que fazem uso das matérias-primas da natureza deveria ser levada de maneira a superar as práticas usuais de degradação e poluição, buscando uma nova interação entre ambos. Sendo que as

\footnotetext{
${ }^{249}$ COMISSÃO MUNDIAL SOBRE MEIO AMBIENTE e DESENVOLVIMENTO. Op. cit. 1988, p. 49.
} 
transformações se dariam de uma forma progressiva, um lento processo de modificação das estruturas que compõem as sociedades e suas economias. ${ }^{250}$

Segundo Ignacy Sachs, o Desenvolvimento Sustentável seria um discurso abrangendo as preocupações dos países "subdesenvolvidos" em relação ao crescimento econômico a fim de atingir os patamares considerados ideais para as nações do planeta, tal como os exemplos europeus ou os Estados Unidos da América. E também atingiria as aspirações de certos grupos no "mundo desenvolvido" quanto à situação do meio ambiente, tanto urbano quanto natural, no qual a exploração sem limites estaria causando prejuízos que poderiam ser irreversíveis se não fossem solucionados de forma rápida e eficaz. ${ }^{251}$

Portanto, entendo-o como um conceito abrangente, atendendo as aspirações de dois tipos de sociedade, e que foi endossado pelos países que participaram da ECO-92, concretizado pelo documento Agenda 21, resultante deste encontro. Tal documento estabeleceu bases, práticas e metas para que os governos que o adotassem seguissem na busca para atingir o que seria considerado um "desenvolvimento sustentável". Entretanto, as iniciativas para que tal conceito fosse considerado pelas sociedades globais vem de um longo processo, que teve origem anos antes.

As bases que definiram o conceito de "desenvolvimento sustentável" podem ser consideradas como anteriores a todos estes momentos. Antes de 1992, quando se torna um conceito político, e antes da década de 1980, com a publicação do "Relatório Brundtland". Novamente, o período inaugural destas discussões se deu na década de 1970. Ascensão do movimento ambiental; debates sobre os estilos de desenvolvimento adotados; das interações entre ser humano e natureza; preocupações com as diferentes

\footnotetext{
${ }^{250}$ COMISSÃO MUNDIAL SOBRE MEIO AMBIENTE e DESENVOLVIMENTO. Op. cit. 1988.

${ }^{251}$ Cf. SACHS, Ignacy. Estratégias de transição para o século XXI: desenvolvimento e meio ambiente. São Paulo: Studio Nobel: Fundação do desenvolvimento administrativo, 1993.
} 
formas de poluição gerada pelas indústrias, automóveis, pessoas; imigração de membros da esquerda para as posições ecologistas, entre outros acontecimentos, marcam a difusão de um conceito que abrangeria as argumentações sobre economia e meio ambiente nos anos de 1970. Ignacy Sachs formula junto a Maurice Strong o conceito de "ecodesenvolvimento" durante a Primeira Conferência da ONU sobre Meio Ambiente em 1972. Partiam do princípio de um capitalismo ecológico, buscando exatamente aquilo que será o teor do "desenvolvimento sustentável" de décadas depois. ${ }^{252}$

Nesse período, marcado pela divisão norte e sul e pela Guerra Fria, as propostas de mudanças no sentido dado ao crescimento econômico esbarravam diretamente nas questões políticas da época. Frear a economia de países do sul representava para esses que estariam sendo controlado pelos do norte, mais "avançados", limitando que os demais pudessem alcançar o mesmo nível de suas economias. Já o bloco comunista acusava o lado capitalista de pretender barrar os avanços industriais que estavam alcançando à custa dos mesmos processos de devastação ambiental constados no bloco capitalista. Portanto, uma encruzilhada, na qual o "ecodesenvolvimento" não teria condições nem ao menos de ser discutido entre as nações. ${ }^{253}$

O desenvolvimento ecológico apresentaria condições para sua aplicação somente na década de 1990. Tal como analisa Maurice Strong em prefácio a uma obra de Sachs do ano de 1993: “[...] Atualmente, as condições são muito mais propícias para se passar do conceito à ação, demonstrando que o ecodesenvolvimento é ao mesmo tempo desejável e possível." 254 . E ainda, o renomeado ecodesenvolvimento poderia, na década

\footnotetext{
${ }^{252}$ Idem.

${ }^{253}$ Idem.

254 STRONG, Maurice. Prefácio. In: SACHS, Ignacy. Estratégias de transição para o século XXI: desenvolvimento e meio ambiente. São Paulo: Studio Nobel: Fundação do desenvolvimento administrativo, 1993.
} 
de 1990, adquirir novos contornos, aprimorando-se em relação ao conceito original de vinte anos antes. ${ }^{255}$

Entretanto, o que houve foi a diversificação dos sentidos dados ao conceito. "Desenvolvimento Sustentável”, "Sustentabilidade”, "Ações Sustentáveis”, "Economia Sustentável”, "Sociedade Sustentável”, entre outros, foram designações utilizadas para tentar definir aquilo que Ignacy Sachs e Maurice Strong pretendiam ao formular inicialmente o termo. Para Sachs o "ecodesenvolvimento" seria:

Um processo criativo de transformação do meio com a ajuda de técnicas ecologicamente prudentes, concebidas em função das potencialidades deste meio, impedindo o desperdício inconsiderado dos recursos, e cuidando para que estes sejam empregados na satisfação da sociedade, dada a diversidade dos meios naturais e dos contextos culturais $[\ldots]{ }^{256}$

Há diversas definições, provenientes de todos os lados interessados: políticos, economistas, biólogos, físicos, historiadores, sociólogos e outros atores. Muito disso se deve à ampla divulgação que teve e também sua capacidade de abordar tantos outros elementos: educação, sociedade, produção, economia, ecossistema, ciências, energia. ${ }^{257}$ Isso permitiu que os debates viessem de todos os lados e que partissem para todos os lados.

A discussão que se dava no âmbito da sociedade civil via muitos
limites no conceito de desenvolvimento sustentável, destacando a
precariedade, a ambigüidade deste conceito que reformava a idéia de
desenvolvimento sem enfrentar suas principais contradições [...]. ${ }^{258}$

Se partirmos de uma análise do significado das palavras que compõem o conceito, segundo o Dicionário Aurélio, desenvolvimento = Adiantamento, crescimento,

\footnotetext{
${ }^{255}$ Idem.

${ }^{256}$ SACHS apud SCOTTO, Gabriela et al. Desenvolvimento sustentável. Petropólis/RJ: Vozes, 2007. p. 26.

${ }^{257}$ Cf. ALMEIDA, Jozimar Paes de. Biodiesel o "Óleo Filosofal”: desafios para a educação ambiental no caldeirão do "Desenvolvimento Sustentável”. Londrina/Pr: Atrito Art Editorial, 2007.

${ }^{258}$ SCOTTO, Gabriela et al. Desenvolvimento sustentável. Petropólis/RJ: Vozes, 2007. p. 47.
} 
aumento, progresso, e o segundo termo do conceito sustentável = Capaz de se manter mais ou menos constante, ou estável, por longo período. Ou seja, se partimos do entendimento puro dos termos, já teremos a contradição colocada: como algo pode progredir ao mesmo tempo em que se mantém estável por longo tempo? Isso também se consolida na relação que tal conceito provoca entre economia e ecologia, entre capital e ecossistema, entre empresários e ecologistas, formando uma equação que torna o discurso sustentável pelo menos digno de desconfiança. Qual seria a eficácia de uma prática sustentável que é paradoxal em si mesma? Plantar e cortar a árvore plantada? Reduzir o lixo, mas aumentar o consumo? Economizar energia ao comprar equipamentos eletrônicos? Manter um padrão de vida pautado pelo excesso e levar a todos os países do planeta esta mesma lógica?

As estruturas nas quais se pautam o capitalismo não suportariam essa relação ecológica. Dessa maneira, o conceito de desenvolvimento sustentável se reduziu de uma proposta de mudança significativa no estilo de vida para uma tentativa de civilizar o capitalismo, ou na compreensão de Paulo Rogério Vargas:

[...] da maneira como está posta, embalada apenas numa 'pregação ecológica', a 'nova' idéia de desenvolvimento sustentável (e sua aceitação), erige-se como a tentativa de implementação de uma proposta de mudança precisamente para se garantir que nada se mude, transformando o discurso da sustentabilidade numa quimera, pura ilusão. ${ }^{259}$

Esta "ilusão", fruto da proposta do desenvolvimento sustentável, teria de ser amarrada exatamente em um dos pilares ideológicos fundamentais do capitalismo na época e que perdura até nossos dias, ou seja, a competitividade. É neste ponto que a

\footnotetext{
259 VARGAS, Paulo Rogério. O insustentável discurso da sustentabilidade. In: BECKER, Dinizar Fermiano (Org.). Desenvolvimento sustentável: necessidade elou possibilidade? 4o. ed. rev. e amp. Santa Cruz do Sul, Edunisc, 2002. p. 237 (grifo do autor).
} 
noção da sustentabilidade perde sua força no meio social, político e econômico, pois os seus teorizadores não conseguem (ou não querem) refletir sobre essa "adversidade".

$\mathrm{Na}$ tentativa de elaborar um esquema de referência para o desenvolvimento sustentável, o autor brasileiro Geraldo Muller, em 2002, quase dez anos após os trabalhos de Sachs, entende como um "desafio imenso" a questão de unir as propostas ecológicas e igualitárias que compõem o conceito, junto à noção de competitividade. ${ }^{260}$ E o desenvolvimento sustentável deveria ser:

[...] simultaneamente competitivo, eqüitativo e ecológico [no qual não se trataria de] reduzir ecologia e equidade aos ditames simples da competitividade ou, de uma maneira simplória, da concorrência ainda que na prática atual dos mercados e suas instituições predomine fortemente a concorrência a qualquer preço [mas, para o autor, seria um preceito] considerar as transações econômicas, suas regulações e coordenações, transpassadas por componentes ecológicos e de equidade [...]. ${ }^{261}$

O que Muller pretende em seu ensaio é encontrar uma solução para o dilema do desenvolvimento sustentável. "A aplicação deste modelo de desenvolvimento sustentável [...]", escreve o autor, "[...] implica na mudança social de atitudes e comportamentos em todos os segmentos sociais, em direção a uma sociedade inovadora". ${ }^{262}$ Ou seja, inovar a sociedade, transformando as estruturas que compõem a lógica sistêmica capitalista do período.

Se houve modificações na maneira de se compreender o conceito de desenvolvimento sustentável ao longo dos anos 1990, este foi pautado pela mesma

\footnotetext{
${ }^{260}$ MULLER, Geraldo. Desenvolvimento sustentável. Notas para a elaboração de um esquema de referência In: BECKER, Dinizar Fermiano (Org.). Desenvolvimento sustentável: necessidade elou possibilidade? 4o. ed. rev. e amp. Santa Cruz do Sul, Edunisc, 2002. p. 117-138.

${ }^{261}$ Idem. p. 131.

${ }^{262}$ Idem. p. 137.
} 
racionalidade, mudanças onde não poderia haver mudanças, pois o termo alteraria em sua proposta todo o modus operandi do sistema econômico-social do planeta.

Mas isto também não significou que o conceito não tenha sido aceito por grande parte da sociedade. Atualmente é muito comum observarmos governos, empresas, comércios, pessoas que adotaram o estilo de vida proposto pelos ideais da sustentabilidade. Evidentemente que o jogo de interesses existe nestas situações, principalmente para o capital. As empresas "sustentáveis" adquirem um novo público para seus produtos e serviços, além de fixar clientelas antigas. Os governos "sustentáveis" utilizam a imagem da sustentabilidade para expor aos cidadãos e outras nações que têm uma administração moderna, podendo trazer contratos e indústrias para seu território.

As ciências também adotam esse discurso e os pesquisadores do PIPGE em energias alternativas o utilizam a partir de 1997, após a assinatura do Protocolo de Kyoto. Quanto à participação dos cientistas dentro da perspectiva da sustentabilidade, isto fica evidente na afirmação de Sachs. "[...] Por um lado, o ecodesenvolvimento é, intrinsecamente, um processo intensivo em conhecimento [...]", destaca o autor em 1993 e que "[...] Cientistas engajados em pesquisa fundamental e pesquisa aplicada têm grandes contribuições a oferecer neste sentido."263 Assim, partindo da ótica do “desenvolvimento sustentável”, haveria a inclusão de várias camadas e grupos da sociedade.

Os cientistas poderiam participar fazendo propostas e pesquisas "sustentáveis". Análise dos ciclos de vida de determinados tipos de produtos, desenvolvimento de materiais biodegradáveis, redução de poluentes dos motores automotivos, e

\footnotetext{
${ }^{263}$ SACHS, Ignacy. Op. cit. 1993. p. 68.
} 
evidentemente, fontes energéticas que tivessem uma melhor relação com o meio ambiente, como as fontes alternativas.

Energia solar, eólica, maremotriz, geotérmica e a biomassa são fontes energéticas que primariam por um condicionante fundamental de serem "ecologicamente limpas". Quer dizer, no seu processo de produção energética não agrediriam o meio ambiente ao seu redor tal como os combustíveis fósseis; portanto, se enquadram na lógica da sustentabilidade. Esta indicação consta também no relatório brasileiro de 1991, que servia como um levantamento para as diretrizes do país na reunião da ONU de 1992. O documento "O desafio do desenvolvimento sustentável", indicava que:

[...] os problemas de meio ambiente e as possibilidades de que se materialize um estilo de desenvolvimento sustentável se encontram diretamente relacionados com os problemas [...] de uma nova matriz energética que privilegie as fontes renováveis e do processo de inovação tecnológica. ${ }^{264}$

O quadro montava-se sobre cenários em que as energias alternativas fossem privilegiadas e ainda as inovações tecnológicas incentivadas, tanto no Brasil quanto em outros países. O interesse, que se sobrepunha até mesmo às questões ambientais e econômicas, vinha da crença de que seria possível em um período de tempo relativo atingir pela pesquisa e desenvolvimento destas fontes o suprimento para as necessidades que se apresentavam. ${ }^{265}$ Podemos entender esse fornecimento de energia em dois sentidos. Primeiro, que a energia fosse abundante, sem risco de haver corte na produção, seja por problemas políticos ou econômicos. Segundo, que tais fontes pudessem ficar a

\footnotetext{
${ }^{264}$ BRASIL (Presidência da República). Comissão Interministerial para Preparação da Conferência das Nações Unidas sobre Meio Ambiente e Desenvolvimento. $O$ desafio do desenvolvimento sustentável. Brasília: Cima, 1991. p. 19.

${ }^{265} \mathrm{Idem}$
} 
cargo das nações, ou melhor, que as nações fossem independentes das demais no quesito energia, podendo produzir em seu território a demanda necessária.

A sustentabilidade energética viria do fato de que os principais países exportadores de petróleo não tivessem mais o controle das fontes energéticas de maior utilização nos países do planeta. Além disso, a natureza deveria garantir uma reserva inesgotável de abastecimento energético, uma "Cocanha" da eletricidade e dos combustíveis. Esta idéia serviria de outra justificativa, já que a primeira seria o choque de 1973, para a pesquisa e desenvolvimento de energias alternativas.

Podemos encontrar estas idéias sobre a natureza e o meio ambiente no PIPGE da USP, quando seus pesquisadores em energias alternativas traziam esta argumentação como um fator de fortalecimento das pesquisas em biomassa de cana ou então em energia solar. Há duas fases para este tipo de idéias. Um primeiro período, de 1992 a 1997, quando se mostrava em segundo plano nos textos, servindo de apoio aos demais argumentos. De 1997 em diante, temos um segundo período, no qual a presença das questões relacionadas ao meio ambiente ganha força e se destaca na análise dos pesquisadores do Programa. A compreensão desta última fase é representativa do conjunto de idéias dos pesquisadores desta linha de pesquisa em relação ao desenvolvimento sustentável.

O Protocolo de Kyoto de 1997 foi significativo para a pesquisa e desenvolvimento de fontes alternativas de energia ${ }^{266}$, levando os pesquisadores do PIPGE a alterarem seu teor argumentativo. Após a assinatura do documento por quase todos os países que participaram da reunião, menos Japão e EUA, os pesquisadores passaram a considerar o debate ambiental com um dos protagonistas de seus trabalhos.

\footnotetext{
${ }^{266}$ Deve-se levar em conta que, apesar do marco de 1997, o Protocolo de Kyoto foi o resultado de uma série de conferências realizadas a partir de 1992. Inclusive seu texto foi discutido até o ano de 2001 e sua ratificação pelos países ocorrendo somente na reunião de cúpula de 2002 , a já citada "Rio + 10 ".
} 
A preocupação geral que se esboçava no protocolo seria com as "mudanças climáticas" causadas pela intensificação no uso dos combustíveis fósseis em processos industriais, agrícolas e nos transportes. ${ }^{267}$ Tais alterações no clima seriam provenientes principalmente do efeito estufa e de sua conseqüência, o aquecimento global.

O Protocolo estabeleceu metas para a diminuição das emissões de gases poluentes e uma série de mecanismos para complementar e permitir que tais objetivos fossem alcançados pelos países que participaram da reunião. ${ }^{268}$ Umas das principais ferramentas foi a elaboração do Mecanismo de Desenvolvimento Limpo (MDL), que, como o próprio nome demonstra, estaria em consonância com o conceito de “desenvolvimento sustentável”.

O artigo de Helena Moreira e Analúcia Giometti de 2008 é particularmente revelador neste sentido. Segundo as autoras, o MDL pode ser considerado como fundamental para o Protocolo de Kyoto e também para as energias alternativas, pois promove uma série de projetos governamentais que visariam à redução das emissões de poluentes, possibilitando aos países envolvidos receberem financiamento de um fundo internacional, dependendo das toneladas de carbono cuja emissão para_as camadas atmosféricas conseguissem evitar anualmente.

[...] O objetivo final da redução das emissões pode ser atingido, assim, por meio da implementação de atividades de projetos nos países em desenvolvimento que resultem na redução das emissões de GEEs [Gases do Efeito Estufa] ou no aumento da remoção de $\mathrm{CO}$, mediante investimentos em tecnologias mais eficientes, substituição de fontes de energia fósseis por renováveis, racionalização do uso da energia, florestamento e reflorestamento, entre outros. ${ }^{269}$

\footnotetext{
${ }^{267}$ Cf. MOREIRA, Helena Margarido e GIOMETTI, Analúcia B. dos Reis. O Protocolo de Quioto e as possibilidades de Inserção do Brasil no Mecanismo de Desenvolvimento Limpo por meio de Projetos em Energia Limpa. In: Contexto Internacional. Rio de Janeiro, vol. 30, n. 1, janeiro/abril, 2008.

${ }^{268} \mathrm{Idem}$.

${ }^{269}$ Ibidem. p.10.
} 
Podemos entender que na prática funcionaria como um escambo de nível planetário. Com uso de tecnologias ambientalmente recomendadas, tal como as relacionadas às energias alternativas, os países que mitigassem os gases do efeito estufa poderiam resgatar somas do fundo internacional que foram ali depositadas por nações que não tivessem atingidos as metas do Protocolo. Foi o chamado "comércio de carbono", tornado o gás um produto a ser comercializado entre os países. Um sistema de trocas, que levaria as nações subdesenvolvidas ou em desenvolvimento a procurar tornar rentável sua industrialização e geração energética, ao mesmo tempo em que as desenvolvidas poderiam pagar pelas atividades ambientais e continuar reproduzindo seu estilo de industrialização, transportes, consumo, entre outros. Exatamente por apresentar em seu conteúdo responsabilidades diferenciadas para cada um dos países envolvidos, resgatando que, dependente do nível de desenvolvimento, estariam obrigados a responder por determinadas metas. Isto possibilitou as nações responsáveis por altos índices de poluição diminuir suas metas no Protocolo, ou até mesmo não o ratificarem, como os EUA e o Japão. Pois as minúcias presentes no documento tornaram possível que o "comércio de carbono" os levassem a negociar com outros países a venda de créditos, ou seja, pagavam para continuar poluindo como anteriormente.

Quanto às fontes alternativas de energia, o Protocolo agiu diretamente nestas tecnologias, estimulando o aumento de sua participação nas matrizes energéticas das nações.

Segundo as autoras Helena Moreira e Analúcia Giometti, no caso brasileiro, os incentivos provenientes do MDL podem ser considerados de fundamental importância para a aplicação das energias alternativas.

O Brasil tem grande potencial para desenvolver energias limpas ou renováveis, principalmente pela sua vocação agroindustrial para o cultivo de produtos como a cana-de-açúcar, usada para produção do 
álcool combustível, e as plantas oleaginosas (mamona, soja etc.), que podem ser utilizadas para a produção de biodiesel, e ainda pelo uso de resíduos agrícolas (madeira, casca de arroz etc.) e industriais (lixo municipal). ${ }^{270}$

Em um texto do PIPGE de 1998 sobre bombeamento de água utilizando a energia fotovoltaica, os pesquisadores Ildo Sauer e Maria Fedrizzi expressam esta relação, indicando não somente a premissa de ser uma tecnologia "[...] de última geração [...]" e, portanto, estariam “[...] permanentemente no debate da problemática energética [...]", mas ressaltam as dificuldades que as fontes tradicionais estavam causando ao meio ambiente "[...] acidificação do ciclo da água, do provável aquecimento global e outros problemas relacionados à saúde dos seres vivos." ${ }^{271} \mathrm{Se}$ a energia solar se insere nas discussões de cunho político sobre a matriz, no caso da biomassa de cana, apresentam o objeto como "[...] conveniente para a sociedade [...]" no qual seu papel como fonte para usinas

[...] apresenta emissões de poluentes mais reduzidas que as térmicas a combustíveis fósseis (mesmo o gás natural, que é o combustível mais limpo de todos os fósseis), principalmente em termos de gases do efeito estufa, responsáveis pelo aquecimento global do planeta. ${ }^{272}$

Destacar os benefícios ambientais das fontes energéticas, ainda mais considerando e trazendo para a discussão outros problemas ecológicos, tal como o efeito estufa e aquecimento global, esteve presente na literatura do PIPGE. Assim como o estado da arte, tão caro aos pesquisadores no capítulo anterior, foi tratado como uma qualidade ambiental, no ano 2000, por Suani Coelho “[...] Por ser mais eficiente, os impactos ambientais são menores - mais ainda no caso da biomassa, pelo balanço

\footnotetext{
${ }^{270}$ Ibidem. p. 33.

${ }^{271}$ FEDRIZZI, Maria Cristina e SAUER, Ildo Luís. Pequenos sistemas de bombeamento fotovoltaico: análise da competitividade com outras opções. In: III Congresso Brasileiro de Energia, 1998. p. 205.

272 COELHO, Suani T. Questão de bom senso. In: Agroanalysis. Rio de Janeiro: Fundação Getulio Vargas, 2000. pp. 31-32.
} 
praticamente nulo das emissões de carbono. ${ }^{273}$ Entretanto, considerar que a biomassa seria um produto que apresenta baixos índices de impacto por emitir quase nada de carbono seria admitir o que em 1992 os pesquisadores ainda não cogitavam, ou não revelavam, pois a mesma pesquisadora Suani Coelho escrevia que "A biomassa é um combustível limpo, que não apresenta enxofre em sua composição, além de manter o equilíbrio de $\mathrm{CO}_{2}$ na atmosfera, através da reabsorção do $\mathrm{CO}_{2}$ emitido durante o processo de fotossintese que ocorre nas plantações [...]." ${ }^{, 274}$, destacando um elemento fundamental: a possibilidade de limpar a atmosfera pelo simples fato de ser uma planta e por isso absorve em seus processos naturais o $\mathrm{CO}_{2}$ do ambiente.

Em relação a este ponto, novamente as pesquisas do PIPGE retomam a historicidade de seu objeto, retomando oProálcool de 1975. Em um documento elaborado por David Zylbersztajn, Eliane Fernandes e Suani Coelho em 1994, utilizado para a campanha presidencial de Fernando Henrique Cardoso, intitulado "Bases para uma politica energética sustentável a longo prazo", os autores demonstram as características de ser uma energia ecológica e abundante na natureza. O benefício ambiental destacaria novamente o álcool em relação à gasolina, pois além de não ter em sua composição os poluentes atmosféricos, permitiu aos motores de automóveis nacionais a controlarem as emissões de materiais a partir do início do programa do álcool. ${ }^{275}$ E sobre a relação entre bagaço de cana e sua abundância como fonte, o texto revela que:

Outro aspecto importante relativo ao Proálcool é a possibilidade de geração de excedentes significativos de eletricidade pelas industrias do setor, a partir do bagaço de cana, um sub-produto do processo de

\footnotetext{
${ }^{273}$ Idem. p. 32.

${ }^{274}$ COELHO, Suani T. Avaliação da cogeração da eletricidade a partir de bagaço de cana em sistemas de gaseificador/turbina a gás. São Paulo: PIPGE (Dissertação de Mestrado), 1992. p. 15 (grifo nosso).

275 ZYLBERSZTAJN, David; FERNANDES, Eliana dos Santos Lima e COELHO, Suani T. Bases para uma política energética sustentável a longo prazo: proposta de estudos referenciais. Sub-grupo Álcool combustivel. São Paulo, 1994.
} 
fabricação de açúcar e álcool, disponível em grandes quantidades $[\ldots]^{276}$

Entretanto, esses autores não relacionam os problemas ambientais causados no quesito meio ambiente, mas o deixam para outro momento: a queima do canavial para a colheita da cana, sua lavagem, o líquido resultante do processo de obtenção do álcool, a vinhaça $^{277}$ ou mesmo na própria cogeração com o bagaço, que segundo os pesquisadores "No método tradicional, usando como combustível nas caldeiras, o bagaço de cana produz particulados nos gases de combustão que devem ser eliminados por filtros". 278

E se não forem utilizados os tais filtros? A poluição será enviada à atmosfera, causando impacto ao meio ambiente?

As formas de poluição geradas pela biomassa da cana geralmente são legadas aos principais produtos, álcool e açúcar, sendo que a fonte energética em si ficaria de fora dos prejuízos ecológicos. Em 1992 Suani Coelho escreveu que:

A produção do açúcar e álcool traz como conseqüência uma série de resíduos poluentes, desde a emissão de poluentes pela queima do canavial até os despejos industriais conseqüentes da fabricação (lavagem da cana, torta de filtro, vinhaça). ${ }^{279}$

A adequação do discurso sobre os impactos ambientais do objeto ocorreu em 1999 na tese de doutorado da pesquisadora. Incorporou então no argumento a comparação entre os poluentes gerados pela cana, neste momento entrado na equação o

\footnotetext{
${ }^{276}$ Idem. p. 16.

${ }^{277}$ O pesquisador do PIPGE Reinaldo Alves Almança caracteriza a vinhaça da seguinte maneira: "[...] $a$ vinhaça pode ser considerada uma suspensão aquosa de sólidos orgânicos e minerais, contendo os componentes do vinho não arrastados na destilação, além de quantidades residuais de açucar, álcool e componentes voláteis mais pesados." Cf. ALMANÇA, Reinaldo Alves. Avaliação do uso da vinhaça da cana-de-açúcar na geração de energia elétrica (estudo de caso). São Paulo: PIPGE (Dissertação de Mestrado), 1994. p. 23.

${ }^{278}$ ZYLBERSZTAJN, David; FERNANDES, Eliana dos Santos Lima e COELHO, Suani T. Op. cit. 1994. p. 6.

${ }^{279}$ COELHO, Suani T. Op. cit. 1992. p. 141.
} 
álcool e o bagaço junto, em relação às demais fontes poluidoras na matriz energética. Traz as chamadas "Externalidades" para justificar que a menor quantidade de emissões de gases nocivos à atmosfera seria ainda preferível do que os combustíveis fósseis. Externalidades seriam os custos que ficariam de fora na contabilização dos custos de um determinado produto, mas que, devido às conseqüências de seu uso em processos industriais ou sociais, indiretamente causariam prejuízos às sociedades; tal conceito procuraria avaliar estes produtos, abarcando nisto os problemas ambientais. ${ }^{280}$ Nesta conta, os principais causadores das emissões de gases na colheita da cana ou na usina de beneficiamento do álcool e açúcar seriam os combustíveis fósseis utilizados direta ou indiretamente na agricultura ou no transporte da safra e do álcool.

[...] quanto se compara corretamente, isto é, as emissões da UTE a GN com as emissões apenas da queima do bagaço (quer dizer, comparando apenas as emissões na geração de eletricidade a partir de dois combustíveis), verifica-se a vantagem significativa da biomassa, mesmo sem considerar a questão do efeito estufa. ${ }^{281}$

Portanto, a argumentação ambiental dos pesquisadores do PIPGE girou em torno da qualificação do objeto como sendo benéfico ao meio ambiente, descaracterizando os poluentes que causavam enquanto menores ou até desprezíveis em relação a outras fontes. Mesmo quando o objeto da pesquisa fosse um dos principais causadores da poluição ambiental, os pesquisadores adaptam os enunciados de forma a minimizar os efeitos que poderiam prejudicar seu argumento. Como no caso da vinhaça, o pesquisador Reinaldo Almança, em 1994, logo na introdução de sua dissertação de mestrado admite que o líquido "[...] chamado de vinhaça da cana-de-açúcar [...] é caracterizado como um grande poluidor, principalmente, se lançado em corpos d'água

\footnotetext{
${ }^{280}$ Ibidem.

${ }^{281}$ COELHO, Suani T. Op. cit. 1999. p. 178.
} 
[...]. ${ }^{, 282}$ Porém, logo em seguida escreve sobre a possibilidade de purificar a vinhaça, mediante a aplicação de processos anaeróbicos. Retira a carga negativa do líquido, ao torná-lo passível de recuperação e uso para a geração energética.

Este procedimento, inferir sobre um problema e logo em seguida descaracterizálo, permite ao cientista modificar seu enunciado, de forma a considerar os pontos de vulnerabilidade do objeto ao mesmo tempo em que remonta sobre eles com considerações que irão alterar os significados para bem representar a pesquisa e o pesquisado, montando um quebra-cabeça que muitas vezes teria lógica apenas para o cientista. Uma forma de mobilizar o mundo ao seu redor, lhe permitindo trazer processos anaeróbicos para a composição de uma tecnologia energética. Não que ambos estejam desligados por uma distância conceitual, mas a abrangência das possibilidades que o entorno do objeto desvela proporciona ao pesquisador sublimar características mediante a utilização de recursos distintos de sua estirpe cientifica, ou, no caso, da engenharia elétrica para a química. ${ }^{283}$ Trazendo para a questão novos argumentos e ferramentas que possibilitariam ao pesquisador argumentar com outros pontos de vista dispares do seu. Para Latour seria nestes momentos presentes na literatura científica que "[...] o mundo se converte em argumentos [...].".284

Quanto à energia solar, a convergência em argumentos leva os pesquisadores do PIPGE a generalizar as questões envolvidas, ou seja, partem de um mesmo argumento amplo, sem adentrar nas minúcias ecológicas, por exemplo. Provavelmente os textos sobre a fonte solar de energia sejam os que mais fazem uso do caráter de renovabilidade como argumento. Os problemas ambientais que poderiam ser causados no processo de fabricação dos materiais que compõem a tecnologia fotovoltaica já foram descritos no

\footnotetext{
${ }^{282}$ ALMANÇA, Reinaldo Alves. Avaliação do uso da vinhaça da cana-de-açúcar na geração de energia elétrica (estudo de caso). São Paulo: PIPGE (Dissertação de Mestrado), 1994. p. 1.

${ }^{283}$ LATOUR, Bruno. Op. cit. 2001.

${ }^{284}$ Idem. p. 120.
} 
final do capítulo anterior. Relembrando, tais questões têm a ver com a extração dos materiais que compõem as células solares, sendo um procedimento de degradação do ambiente no qual estes materiais se encontram.

A incidência do argumento da renovabilidade das fontes alternativas continuou por todo o período analisado em trabalhos que ressaltam os benefícios da energia solar fotovoltaica. "[...] é de fundamental importância para o estabelecimento das tecnologias baseadas na exploração das fontes renováveis não convencionais, como o caso da energia fotovoltaica [...]",285, afirma Maria Julita Guerra Ferreira em 2002. Ou então Roberto Zilles, docente do PIPGE, em 2001, relatando para o Jornal da USP os benefícios que a universidade teria com os equipamentos fotovoltaicos instalados no ano 1998 no prédio que abriga o Programa: “[...] Para a USP em particular [...] possibilitará iniciar os debates sobre as novas metas definidas em Kyoto, redução de emissões de carbono e mecanismo de negociação com a bolsa [...]",286, destacando a relação da fonte energética com o documento de Kyoto. Assim como os pesquisadores escreveram sobre as vantagens ao "desenvolvimento sustentável" dos projetos de eletrificação rural e de comunidades isoladas que utilizavam a energia solar

[...] torna-se necessário buscar soluções energéticas de geração autônoma para as populações isoladas, visando promover o acesso à energia elétrica a toda a população, indistintamente de sua condição econômica ou localização geográfica. E estas soluções serão tanto melhores, quanto mais baratas e menos prejudiciais para o ambiente forem. ${ }^{287}$

\footnotetext{
285 FERREIRA, Maria Julita Guerra. Experiência de projetos fotovoltaicos no Estado de São Paulo: modelagem para planejamento energético em comunidades isoladas. São Paulo: PIPGE, (Tese de Doutorado), 2002. p. 130.

${ }^{286}$ ZILLES, Roberto. As promissoras dádivas que vêm do céu. In: Jornal da USP, 2001. p. 13.

287 FEDRIZZI, Maria Cristina e SAUER, Ildo Luís. Pequenos sistemas de bombeamento fotovoltaico: análise da competitividade com outras opções. In: III Congresso Brasileiro de Energia, 1998. p. 206.
} 
O discurso levava os leitores a caminhar sempre no sentido de uma mesma conclusão: que a energia solar era benéfica para o uso no meio social. Necessitaria somente de mais incentivos e financiamentos para o desenvolvimento da tecnologia em direção ao seu melhor desempenho e aplicação no meio social.

$\mathrm{O}$ argumento continua jogando para o futuro a certeza de um sistema energético que iria substituir todos os outros. Sendo considerado com a "solução do abastecimento energético" por um pesquisador do PIPGE em 1997, pois

O sol fornece anualmente para a atmosfera terrestre cerca de $5,51 \times 10^{24}$ $\mathrm{J}$, isto é $1,53 \times 10^{18} \mathrm{KWh}$ por ano. Esta é uma quantidade significativa de energia. Para dar uma idéia da magnitude deste valor, toda a energia primária consumida no planeta, ao longo do ano de 1993 foi de 7,80 GTEP, ou seja, 9,06×10 ${ }^{14} \mathrm{KWh}$, cerca de 0,0595 deste valor. $^{288}$

O sol seria a principal usina geradora de energia, podendo vir a substituir outras formas tradicionais de geração, principalmente no Brasil, como as hidrelétricas. Segundo Célio Bermann, docente do PIPGE, a capacidade de geração elétrica é quase infinita, tanto que chega a afirmar que: “[...] Se cobríssemos a área da usina de Itaipu $\left(1.350 \mathrm{~km}^{2}\right)$ com painéis solares fotovoltaicos, ele gerariam toda a energia elétrica consumida no país (330 bilhões de $\mathrm{kWh}$ ) [... $]^{, 289}$, com a ressalva de que a quantidade necessária de painéis solares para tal empreendimento seria de cem vezes aquilo que o mundo produz anualmente. Há, portanto, a tecnologia para ser utilizada; no entanto, economicamente estaria limitada pelas possibilidades de fabricação dos equipamentos que tornasse viável tal empreitada.

\footnotetext{
${ }^{288}$ OLIVEIRA, Sérgio Henrique Ferreira de. Dimensionamento de sistemas fotovoltaicos autônomos: ênfase na eletrificação de residências de baixo consumo. São Paulo: PIPGE (Dissertação de Mestrado), 1997. p. 52.

${ }^{289}$ BERMANN, Célio. Energia no Brasil: para quê? para quem? Crise e alternativas para um país sustentável. São Paulo: Editora da Livraria da Física/FASE, 2001. p. 24.
} 
A literatura do Programa Interunidades não destoa deste ponto de vista econômico e tecnológico. Todos os pesquisadores, sem exceção, aplicam esses argumentos em suas teses, dissertações, artigos, papers. Entretanto, o discurso ambiental da energia solar esteve presente apenas em textos publicados no Brasil. Em eventos de âmbito internacional, quando escreviam em inglês, não inseriam estes fatores nos trabalhos. Será que somente no Brasil era necessário este tipo de argumentação?

Por fim, houve no PIPGE/Energias Alternativas toda uma literatura que vinculava seus objetos de pesquisa a uma idéia geral: a possibilidade de renovação $a d$ infinitum de suas fontes. A abundância da natureza resgatada para o uso e abuso das sociedades modernas. Os pesquisadores vinculavam historicamente suas pesquisas a outras para fortalecer seus argumentos, especialmente para justificar o porquê de realizá-las. Ora, quem não gostaria de poder contar com um suprimento eterno de energia, se esbaldando na “Cocanha” energética do sol e da cana? 
"[...] Poder-se-ia dizer que a energia é para o mundo mecânico o que a consciência é para o mundo humano. Se a energia falha, tudo o mais falha"

(E.F. Schumacher, 1991)

"O problema energético é um problema social" (Elmar Altvater, 1995) 


\section{CONCLUSÃO}

A pesquisa para esta dissertação se mostrou uma grata surpresa, recheada de descobertas, realizações e algumas decepções. Acontecimentos comuns no ofício de historiador, mas se, como escreveu Marc Bloch na obra "Apologia da História", a história é a ciência dos homens no tempo, então estes episódios refletem o objeto de trabalho, algo puramente humano. ${ }^{290}$ Busquei realizar um trabalho historiográfico que pudesse acrescentar um pedaço às migalhas perdidas do passado, colocar no palco do tempo os atores com suas falas e, quem sabe, compreendê-los.

Esta dissertação teve como objetivo compreender a produção científica sobre energias alternativas no Estado de São Paulo entre 1992 e 2002. Tal proposta se deu mediante questões gerais e específicas em relação à temática e que deram o mote das partes que compõem esta análise. A análise se desenvolveu a partir da documentação de um determinado grupo de pesquisadores (PIPGE/USP) em sua linha de pesquisas: energias alternativas.

De maneira geral, estabeleci a conjuntura histórica anterior em que se basearam tais atividades, destacando os principais acontecimentos no âmbito internacional, nacional e regional, assim como as motivações e justificativas que levaram os cientistas a desenvolverem pesquisas nesta área.

Inicialmente procurei mostrar que a energia, conceito definido no século XIX, ganhou traços de mercadoria no século XX, saindo de uma categoria abstrata para algo concreto, tendo significados palpáveis em meio à sociedade ocidental. Tal concretização na forma de combustíveis ou da eletricidade insere-a na lógica de mercado, de venda da

\footnotetext{
${ }^{290}$ Cf. BLOCH, Marc. Apologia da Historia, ou, O Oficio do Historiador. Rio de Janeiro: Jorge Zahar,
} 2001. 
energia como mercadoria, como, por exemplo, não sendo mais uma prática a procura de lenha para os fins domésticos, mas a vinda de um cabo que contém energia (elétrica) na porta das casas, desde que o morador pagasse o preço pelo serviço. Além disto, os processos industriais e a mecanização dos serviços de transportes utilizavam cada vez mais as fontes energéticas disponíveis para a época e que estimulavam o desenvolvimento de novas fontes. O mundo ocidental se mostrava cada vez mais rápido, os processos fabris e a velocidade atingida pelos trens a vapor e veículos motorizados, ao final do século XIX, levava à aceleração do tempo em que as sociedades humanas se acostumaram a viver. A energia possibilitava a execução de tarefas e estabelecia novas regras de eficiência, atendendo as perspectivas do capitalismo, caracterizando-se como a "espinha dorsal" de todo este sistema.

Em seguida analisei o contexto de formação do setor energético até os anos de 1990, mediante a caracterização das matrizes energéticas mundial e brasileira. Se mundialmente o petróleo e o carvão dominaram o período, teremos no caso brasileiro, e o estado de São Paulo não fugia a esta regra, a utilização maciça de duas fontes energéticas, o petróleo e a hidroeletricidade, sendo preferidas em relação a outras formas energéticas que também compunham a matriz: a energia nuclear e o álcool.

No ano de 1990 se deu início no Brasil o Programa de Desestatização do Governo Federal. Esse processo previa a venda de companhias estatais ao capital privado, procurando dinamizar tais empresas, abrindo novos mercados e criando a concorrência nos serviços públicos. As companhias energéticas também estavam incluídas nesse programa, visando ao aumento do potencial de geração de energia elétrica no território, atendendo a crescente demanda que se verificava, ou seja, 5\% ao ano em todas as regiões do país. No caso de São Paulo, as companhias estaduais foram vendidas em 1995, consolidando a criação de um mercado energético nacional. 
Como mostrei, as Conferências das Nações Unidas sobre meio ambiente, realizadas de dez em dez anos desde 1972, já vinham destacando a necessidade de os países em investirem na pesquisa e adotarem fontes alternativas na geração energética em seus territórios. Além disso, apresentei os resultados dessas Conferências na América Latina, no Brasil e no Estado de São Paulo, e também legislações que promoveram a introdução de tecnologias em energias alternativas na matriz nacional e estadual.

Esses eventos criaram cenários favoráveis para as pesquisas em energias alternativas, como aquelas desenvolvidas pelos cientistas do PIPGE no Estado de São Paulo na década de 1990 e início dos anos 2000. Esse grupo procurou desenvolver trabalhos sobre energia, e também fontes alternativas, sob vários questionamentos interdisciplinares.

O estudo de caso realizado, de um programa de pós-graduação da Universidade de São Paulo que faz pesquisas em energia, foi adequado para o direcionamento da análise, pois o mesmo se caracterizou enquanto formador de quadros científicos e institucionais na área, e que desenvolvia uma pesquisa sobre energias alternativas visando às esferas estadual e nacional.

Entendo que, com a estrutura do PIPGE montada visando desenvolver a crítica ao setor energético, esse se direcionou para a formação de uma tecnocracia especializada para compor os quadros de empresas energéticas, estatais ou privatizadas. Exatamente por privilegiar o mercado de trabalho, ao propor um ensino de pósgraduação que insira seus pesquisadores na ótica do sistema em vigência, podemos perceber que o Programa atua na formação de trabalhadores, no caso, como consta na proposta enviada a CAPES, de "profissionais de alto nivel", para atender as 
necessidades do mercado energético nacional ou internacional, já que suas redes são mais amplas que as fronteiras do Estado de São Paulo ou mesmo do país.

Quanto ao discurso científico sobre energias alternativas, percebo algumas características que marcam os trabalhos dos pesquisadores do PIPGE. Nas primeiras dissertações, as tecnologias ainda se mostram relativamente novas e desconhecidas nacionalmente; portanto, deveriam ser apresentadas ao público interessado. Após as primeiras dissertações defendidas, percebi que ocorreram nos trabalhos posteriores direcionamentos específicos para cada tecnologia. As mudanças podem ser datadas entre 1994 e 1995, com a privatização das companhias estatais, inaugurando um novo mercado de energia, no qual as fontes alternativas poderiam ser introduzidas. Esta nova postura frente ao contexto levou os pesquisadores do PIPGE a determinarem os leitores para seus textos, sendo eles os técnicos e especialistas das empresas privadas, o governo estadual e federal, além de buscarem nos usuários das tecnologias alternativas informações sobre o funcionamento das mesmas.

O Programa concentrou suas atividades em duas tecnologias de energias alternativas: a energia solar fotovoltaica e a biomassa de cana. Ambas as fontes alternativas tiveram semelhanças e também diferenças no tratamento dado pelos pesquisadores. As semelhanças ficaram por conta das barreiras que impediam as tecnologias de serem utilizadas na matriz energética paulista, e as diferenças se deram nos encaminhamentos que estas tiveram quanto às perspectivas dos pesquisadores do Programa.

Neste período ocorreu também por parte dos pesquisadores a busca de cenários ideais para a promoção e a introdução das tecnologias. A partir de então, a análise das fontes documentais mostrou que houve neste quesito a diferenciação entre biomassa e energia solar. A primeira privilegiaria a sua aplicação em larga escala dentro do cenário 
energético estadual, enquanto a segunda procurou se estabelecer como uma alternativa para geração em baixa escala, principalmente nos programas sociais de eletrificação promovidos pelo governo brasileiro.

A partir da relação entre contexto histórico e discurso, as fontes documentais analisadas se referem às barreiras para a inserção da biomassa da cana e da energia solar fotovoltaica na matriz energética nacional, e que podem ser agrupadas em três esferas: tecnológica, política e econômica. As barreiras tecnológicas dizem respeito ao nível de confiabilidade de cada fonte energética, seu desenvolvimento e o tipo de aplicação em que seria possível utilizá-las, pequena ou larga escala. Politicamente, os pesquisadores do PIPGE deram a entender que haveria certo conservadorismo nas decisões provenientes do Governo e até mesmo dos usuários, quanto à aplicação da tecnologia, os mecanismos de incentivo e financiamento para a geração, além da preferência por instalações hidroelétricas. E economicamente, os custos da instalação do equipamento, preços de venda da energia para as concessionárias e a questão da descentralização da geração energética.

Por meio da análise das fontes documentais do Programa junto à bibliografia sobre o tema, pude traçar as idéias que fundamentaram as pesquisas em energia solar e biomassa de cana, chegando à conclusão de que existe um conjunto de idéias, utilizado pelos cientistas, que servia para justificar a continuidade dos trabalhos, seja pelas vantagens para outros programas energéticos ou então pelos resultados atingidos quando foi dado o incentivo à tecnologia.

O conjunto de idéias em que se fundou a pesquisa em energias alternativas podem ser divididas em dois grupos. O primeiro grupo é proveniente do "Choque do petróleo" de 1973 e o segundo do conceito de "desenvolvimento sustentável" a partir de 1997. 
O "choque" da década de 1970 serviu para colocar em pauta entre as nações a questão da escassez do petróleo e a urgência em desenvolver novas tecnologias para a substituição desse combustível fóssil a médio e longo prazo. Especificamente, os pesquisadores em biomassa do PIPGE utilizaram o acontecimento para evidenciar o Programa do Álcool, pois a tecnologia em biomassa para cogeração seria proveniente deste programa brasileiro. Os investimentos nesta tecnologia poderiam, além de garantir o fornecimento energético para o país, também servir para auxiliar o Proálcool na crise que estaria enfrentando nos anos 1990, ao estimular o crescimento da produção e o barateamento dos custos do combustível. Quanto à energia solar, esta se embasou nos progressos tecnológicos que poderiam ser verificados a partir da década de 1970 e que poderiam continuar superando os estágios atingidos pela tecnologia, desde que as pesquisas fossem devidamente financiadas.

No outro conjunto de idéias, temos a utilização por parte dos pesquisadores de uma mesma base, a renovabilidade da matéria-prima das fontes energéticas. Tanto a biomassa quanto a energia solar não enfrentariam o problema da escassez, servindo como um combustível infindável, abundante na natureza. Tais idéias ainda eram relacionadas pelos pesquisadores ao conceito de "desenvolvimento sustentável", encaixando as características das fontes alternativas nas propostas de sustentabilidade entre meio ambiente e desenvolvimento econômico.

Considero, por fim, que as modificações que o conceito de energia sofreu ao longo do século XIX e do XX, ao ser tratada como uma mercadoria fundamental para as sociedades modernas, possibilitou que a pesquisa e desenvolvimento de novas fontes energéticas se transformassem em uma questão básica para as nações nesse período. Porém, no caso das energias alternativas, considerando as tecnologias energéticas ainda incipientes em sua utilização social, a pesquisa destas teria que atingir tanto questões 
científicas quanto políticas, pois os cientistas deveriam convencer seus leitores das vantagens de seu uso.

No estudo de caso, o PIPGE/USP, o lado político necessário para que os pesquisadores atingissem os objetivos determinados, para as tecnologias com que trabalhavam, foi pautado por barreiras impostas pelas companhias energéticas privatizadas e pelo Governo do Estado de São Paulo e também do Brasil, que muitas vezes limitaram a utilização social das fontes alternativas; portanto, os pesquisadores não conseguiram convencer seus leitores de forma plena a respeito das capacidades que a energia solar e a biomassa tinham para oferecer para a matriz energética, estadual ou nacional.

Finalizo acrescentando que hoje em dia a energia faz parte da consciência dos seres humanos, é algo comum no cotidiano, é parte integrante das preocupações, anseios e necessidades sociais; portanto, a análise deste conceito se torna fundamental para o conhecimento de nossa realidade, já que a energia é combustível vital à manutenção das sociedades capitalistas. 


\section{FONTES}

\section{Legislação Federal}

Lei No. 10.438, de 26 de Abril de 2002.

Medida Provisória No. 14 de 21 de Dezembro de 2001.

Resolução No. 91, de 21 de Dezembro de 2001.

Decreto $\mathrm{S} / \mathrm{N}^{\circ}$, de 27 de dezembro de 1994.

\section{Fontes/Governo do Estado de São Paulo}

SÃO PAULO (ESTADO). A batalha da energia no governo Montoro. São Paulo: PW, 1987.

SÃO PAULO (ESTADO). SECRETARIA DE ESTADO DE ENERGIA. Balanço Energético do estado de São Paulo (BEESP) 1994. Ano base: 1993/ Secretária de Energia, Recursos Hídricos e Saneamento. São Paulo: Cesp, 1994.

. Balanço Energético do estado de São Paulo (BEESP) 1995. Ano base: 1994/ Secretária de Energia, Recursos Hídricos e Saneamento. São Paulo: Cesp, 1995.

. Balanço Energético do estado de São Paulo (BEESP) 1996. Ano base: 1995/ Secretária de Energia, Recursos Hídricos e Saneamento. São Paulo: Cesp, 1996.

. Balanço Energético do estado de São Paulo (BEESP) 1997. Ano base: 1996/ Secretária de Energia, Recursos Hídricos e Saneamento. São Paulo: Cesp, 1997.

- Balanço Energético do estado de São Paulo (BEESP) 1998. Ano base: 1997/ Secretária de Energia, Recursos Hídricos e Saneamento. São Paulo: Cesp, 1998.

. Balanço Energético do estado de São Paulo (BEESP) 1999. Ano base: 1998/ Secretária de Energia, Recursos Hídricos e Saneamento. São Paulo: Cesp, 1999.

. Balanço Energético do estado de São Paulo (BEESP) 2000. Ano base: 1999/ Secretária de Energia, Recursos Hídricos e Saneamento. São Paulo: Cesp, 2000 .

Balanço Energético do estado de São Paulo (BEESP) 2001. Ano base: 2000/ Secretária de Energia, Recursos Hídricos e Saneamento. São Paulo: Cesp, 2001. 
. Balanço Energético do estado de São Paulo (BEESP) 2002. Ano base: 2001/ Secretária de Energia, Recursos Hídricos e Saneamento. São Paulo: Cesp, 2002.

. Balanço Energético do estado de São Paulo (BEESP) 2003. Ano base: 2002/ Secretária de Energia, Recursos Hídricos e Saneamento. São Paulo: Cesp, 2003.

SÃO PAULO (ESTADO). SECRETARIA DE ENERGIA, RECURSOS HÍDRICOS E SANEAMENTO. Matriz Energética do Estado de São Paulo 2006 a 2016. Série de Informações Energéticas No. 006. Secretária de Energia, Recursos Hídricos e Saneamento, 2005.

SÃO PAULO (ESTADO). SECRETARIA DE ESTADO DO MEIO AMBIENTE. Agenda 21: a experiência paulista desde 1992. 2.ed. São Paulo:SMA, 2003.

\section{Fontes/PIPGE}

\section{Estatutos do PIPGE (1989 a 2003)}

Universidade de São Paulo. Resolução $N^{o}$ 3482, de 17 de Janeiro de 1989. . Resolução $N^{\circ} 4002$, de 7 de Junho de 1993. . Resolução $N^{o}$ 4436, de 11 de Agosto de 1997. . Resolução $N^{o}$ 5087, de 05 de Dezembro de 2003.

\section{Relatórios para CAPES}

CAPES. Avaliação da pós-graduação. Interunidades em Energia, 2002 . Relatório INTERUNIDADES EM ENERGIA / USP (NRD6) - 1998. . Relatório INTERUNIDADES EM ENERGIA / USP (NRD6) - 2005.

\section{Entrevistas}

Prof. Dr. Murilo Fagá, entrevista cedida em 25 de Novembro de 2008.

\section{Teses e Dissertações}

ALMANÇA, Reinaldo Alves. Avaliação do uso da vinhaça da cana-de-açúcar na geração de energia elétrica (Estudo de Caso). São Paulo: PIPGE (Dissertação de Mestrado), 1994. 
BOLIGNINI, MARLY FRÉ. Externalidades na produção de álcool combustível no estado de São Paulo. São Paulo: PIPGE (Dissertação de Mestrado), 1996.

COELHO, Suani Teixeira. Avaliação da cogeração de eletricidade a partir de bagaço de cana em sistema de gaseificados e turbina a gás. São Paulo: PIPGE (Dissertação de Mestrado), 1992.

- Mecanismos para implementação da cogeração de eletricidade a partir da biomassa: um modelo para o estado de São Paulo. São Paulo: PIPGE (Tese de Doutorado), 1999.

FEDRIZZI, Maria Cristina. Fornecimento de água com sistemas de bombeamento fotovoltaicos: dimensionamento simplificado e análise de competitividade para sistemas de pequeno porte. São Paulo: PIPGE (Dissertação de Mestrado), 1997.

FERREIRA, Maria Julita Guerra. Inserção da energia solar fotovoltaica no Brasil. São Paulo: PIPGE (Dissertação de Mestrado), 1993.

- Experiência de projetos fotovoltaicos no estado de São Paulo: modelagem para planejamento energético em comunidades isoladas. São Paulo: PIPGE (Tese de Doutorado), 2002.

MACHADO, Fernando T. H. F. A utilização do ônibus a gás natural comprimido na frota de ônibus urbanos como alternativa para o redução da poluição atmosférica na região metropolitano de S.P. São Paulo: PIPGE (Dissertação de Mestrado), 1996.

PAULA, Ericson de. A integração energética da América Latina iniciando pelos países do cone Sul: o caso Argentina - Brasil. São Paulo: PIPGE (Dissertação de Mestrado), 1993

PELLEGRINI, Maria Cristina. Inserção de centrais cogeradoras a bagaço de cana no parque energético do estado de São Paulo: exemplo de aplicação de metodologia para análise dos aspectos locacionais e de integração energética. São Paulo: PIPGE (Dissertação de Mestrado), 2002.

OLIVEIRA, Sergio Henrique Ferreira de. Dimensionamento de sistemas fotovoltaicos autônomos: ênfase na eletrificação de residências de baixo consumo. São Paulo: PIPGE (Dissertação de Mestrado), 1997.

- Geração distribuída de eletricidade: inserção de edificações

fotovoltaicas conectadas à rede no estado de São Paulo. São Paulo: PIPGE (Tese de Doutorado), 2002.

SERPA, Paulo Marcos Noronha. Eletrificação fotovoltaica em comunidades caiçaras e seus impactos sócios-culturais. São Paulo: PIPGE (Tese de Doutorado), 2001.

TRIGOSO, Federico Morante. Demanda energética em Solar Home Systems. São Paulo: PIPGE (Dissertação de Mestrado), 2000.

\section{Livros publicados/organizados ou edições:}

COELHO, S. T. (Org.). I Encontro Parcerias para Desenvolvimento Tecnológico e Industrial em Bioenergia. 1998.

COELHO, S. T. Biomassa - Guia do Investidor. CENBIO / ANEEL, 1998. 
COELHO, S. T. (Org.); BOLOGNINI, M. F. (Org.); SILVA, O. C. (Org.); SEGER, S. (Org.); GOMES FILHO, A. (Org.); AMOROSO, L. A. M. (Org.); VARKULYA JR, A. (Org.); SOUZA, C. M. (Org.). Parcerias para o desenvolvimento Tecnológico e Industrial em Bioenergia. 1998. v. 2.

COELHO, S. T. e FERNANDES, E. (Orgs.). Perspectivas do Álcool Combustível no Brasil. 1. ed. São Paulo: IEE/USP, 1996. v. 1.

GOLDEMBERG, José \& VILLANUEVA, Luz D. Energia, meio ambiente $e$ desenvolvimento. São Paulo: EDUSP, 2003.

GOLDEMBERG, José. Energia nuclear no Brasil: as origens das decisões. São Paulo: HUCITEC, 1978.

ZYLBERSZTAJN, David; FERNANDES, Eliana dos Santos Lima e COELHO, Suani T. Bases para uma política energética sustentável a longo prazo: proposta de estudos referenciais. Sub-grupo Álcool combustível. São Paulo, 1994.

\section{Capítulos de livro}

COELHO, S. T.; GOLDEMBERG, J.; TURKENBURG, W. Renewable Energy Technologies. In: W. Turkenburg. (Org.). World Energy Assessment - Energy and Challenge of Sustainability. 1a. ed. New York: UNDP, 2000, v. 1, p. 219-272.

FEDRIZZI, M. C.; NODA, Sandra Do Nascimento; MENDONÇA, Marco Antonio de Freitas; MARTINS, Ayrton Lui Urizzi Martins; MARTINS, Lucia Helena Pinheiro; NODA, Hiroshi; ZILLES, Roberto; PAIVA, Maria Silvesnízia da Silva. Educação e Desenvolvimento Sustentável: a inserção do programa Vento Norte no Projeto de Desenvolvimento Sustentável do Alto Solimões. In: SCALABRIS, Rosemeri; SILVA, Ricardo Gilson da Costa; LIMA, Antonia Américo Biandi (Orgs.). Trabalho e Desenvolvimento na Amazônia: As alternativas da CUT. 2002, v. 1, p. 281-316.

GOLDEMBERG, José. Pesquisa e Desenvolvimento na área de Energia. São Paulo em Perspectiva Ciência e Tecnologia. 3 ed. São Paulo: www.seade.gov.br, 2000, v. 14, p. 91-97.

SERPA, Paulo. Sistema Energético Caiçara: Um conceito em construção. In: DIEGUES, Antonio Carlos . (Orgs.). Enciclopédia Caiçara. São Paulo: NUPAUB-USP \& HUCITEC, 2004.

\section{Artigos em jornais e revistas}

COELHO, S. T.; GOLDEMBERG, J.; REI, F. Brazilian Energy Matrix and Sustainable Development. In: Energy for Sustainable Development. p. 55 - 59, 01 dez. 2002.

COELHO, S. T.; BOLOGNINI, M. F.; PALETTA, C. E. M.; SEGER, S. Energy from biomass in Brazil: the Declaration of Recife. In: Greentimes. Holanda, p. 1 - 2, 03 jul. 2000 .

COELHO, S. T. Fontes alternativas: Questão de bom senso. In: Revista Agroanalysis. Fundação Getúlio Vargas, São Paulo, v. 20, p. 31 - 32, 15 mar. 2000. 
COELHO, S. T. A cogeração de eletricidade a partir de biomassa no setor industria - 1a. parte. In: Revista Alcobrás. São Paulo, v. 51, p. 41 - 45.

COELHO, S. T. A cogeração de eletricidade a partir de biomassa no setor industrial 2a. parte. In: Revista Alcobrás. São Paulo, p. 40 - 45.

COELHO, S. T.; GOLDEMBERG, J.Renewables Energy - Traditional Biomass vs Modern Biomass. In: Energy Policy. p. 711 - 714.

COELHO, S. T.; GOLDEMBERG, J.; LUCON, O. How adequate policies can push renewables. In: Energy Policy. p. 1.141 - 1.146.

FERREIRA, Maria Julita Guerra. Geração Fotovoltaica: uma opção emergente. In: Volts. São Paulo, 01 mar. 1997.

GOLDEMBERG, José. O papel das energias renováveis. Jornal O Estado de S. Paulo, 31/10/2000. p. A2

OLIVEIRA, S. H. F; ZILLES, R. Sistema de geração de energia elétrica com células fotovoltaicas integradas em edificações. In: Téchne. Brasil, p. 69 - 71.

SERPA, Paulo; GANDRA, M. L. Moradores de Bairro rural de Cananéia administram seu próprio sistema de energia solar. In: $A G B$ - Informa. São Paulo, v. 63.

ZILLES, Roberto. As promissoras dádivas que vêm do céu. IN: Jornal da USP, 2001. p. 13

. Atividades de pesquisa em energia solar fotovoltaica no IEE/USP. In:

CRESESB Informe. ano V, n. 6, setembro, 2000.

\section{Publicações em Periódicos}

COELHO, S. T.; GOLDEMBERG, J.; REI, F. Brazilian Energy Matrix and Sustainable Development. In: Energy for Sustainable Development. v. 4, p. 55-59, 2002.

COELHO, S. T.; LUCON, O. Depois da Rio+10: As lições aprendidas em Joanesburgo. In: Revista do Departamento de Geografia, v. 15, p. 11-18, 2002.

FEDRIZZI, M. C.; FREITAS, M. A. V.; STEMMER, C. E.; MOREIRA, J.R.; CAMPOS, I. A.; ZILLES, Roberto; FABRIZY, M. P.; FEITOSA, E.; CORREIA, F.; FAGÁ, M. T. W.; MAZZON, L. A.; PEREIRA, O. S. O Foro Permanente das Energias Renováveis e o Desenvolvimento da Energias Solar, Eólica, da Biomassa e das Pequenas Centrais Hidroelétricas no Brasil. In: Revista Brasileira de Energia, v. 6, n. 1, p. 121-156, 1997.

FEDRIZZI, M. C.; SAUER, Ildo Luis; ZILLES, Roberto. Economic Analysis of Photovoltaic an Gasoline Pumping Systems. In: Renewable Energy, Inglaterra, v. 8, n. 1-4, p. 424-427, 1996.

OLIVEIRA, S. H. F.; ZILLES, R. Grid-connected Photovoltaic Systems: The Brasilian Experience and the Performance of an Installation. In: Progress In Photovoltaics, Inglaterra, v. 9, n. 5, p. 341-347, 2001. 
SERPA, Paulo; ZILLES, R.; Lorenzo, Eduardo. From candles to PV electricity: a fouryear experience at Iguape-Cananéia, Brazil. In: Progress in Photovoltaics: Research and Appliacations, New York, v. 8, p. 421-434, 2000.

SERPA, Paulo. Energia Solar Fotovoltaica: Uma Alternativa Energética para a Promoção do Desenvolvimento Sustentável. In: Resenha Econômica Cepam, São Paulo, v. $17,1998 . \mathrm{s} / \mathrm{p}$.

Aspectos Socioambientais dos Projetos de Eletrificação Fotovoltaica em Comunidades Isoladas. In: O futuro da energia renovável para o século XXI. São Paulo: International Business Communications-IBC, 1998. s/p.

\section{Trabalhos em anais de eventos}

ABREU, Yolanda Vieira de, \& SAUER, Ildo Luis. A reestruturação do setor elétrico brasileiro: questões e perspectivas. In: Anais do Congresso Brasileiro de Energia $C B E$. Rio de Janeiro: Sociedade Brasileira de Planejamento Energético/COPPEUFRJ/Clube de Engenharia, 1999. pp. 662-679

COElHO, S. T.; PALETTA, C. E.; VARKUlYA JR, A.; GUARDABASSI, P.; PEREIRA, O. S. Utilização dos Conceitos de Energia para Análise Técnica e Econômica da Cogeração: Estudo de Caso em Indústrias de Madeira da Amazônia. In: XVI COBEM - Brazilian Congress on Mechanical Engineering. 2001.

COELHO, S. T.; PALETTA, C. E.; VARKULYA JR, A.; GUARDABASSI, P.; PEREIRA, O. S. Geração de Eletricidade na Amazônia Através de Florestas Plantadas: Análise Técnico-Econômica de Geração de Biomassa. In: XVI COBEM - Brazilian Congress on Mechanical Engineering. 2001.

COELHO, Suani T., VARKUlYA JR. Américo, PALETTA, Carlos Eduardo M. e SILVA, Orlando Cristiano da. A importância e o potencial brasileiro da cogeração de Energia a partir da biomassa. In: Gazeta Mercantil/Seminário "Cogeração De Energia”. São Paulo, Outubro, 2001. s/p.

COElHO, S. T.; BOlOGNINI, M. F.; PAlETTA, C. E.; GUARDABASSI, P. Evaluation of externalities in sugar cane origin cogeneration process in Brazil. In: First Conference On Biomassa For Energy And Industry. Sevilla, 2000.

COELHO, S. T.; MOREIRA, J. R.; ZYLBERSZTAJN, D. Evaluation of biomass-based electricity costs through thermoeconomic analysis: study case for sugarcane sector. In: Developmentes In Thermochemical Biomassa Conversion. Seefeld/Tyrol, 2000,

COELHO, S. T.; VARKULYA JR, A.; VELÁZQUEZ, S. M. S. G. Oportunidades de Negócio do Protocolo de Quioto para o Segmento de Papel e Celulose. In: $32^{\circ}$ Congresso Anual de Papel e Celulose. São Paulo, 1999.

COELHO, S. T.; MOREIRA, J. R.; CAMPOS, I. A.; OLIVERIA, A. C. Proposals for the Improvement of Biomass Participation in the Brazilian Energy Matrix: the Declaration of Recife. In: IV Biomass Conference Of The Americas. 1999, Oakland, Califórnia. 1999. 
COElHO, S. T.; VARKulyA JR, A.; VELÁZQuEZ, S. M. S. G. A Cogeração de Eletricidade no Setor de Papel e Celulose: avaliação técnica e econômica. In: XV Congresso Anual de Celulose e Papel. Águas de Lindóia, 1999.

COELHO, S. T.; ZYLBERSZTAJN, D. Barreiras e Mecanismos de Implementação à Cogeração de Eletricidade a Partir de Biomassa. In: III Congresso Brasileiro de Planejamento Energético. São Paulo, 1998.

COELHO, Suani T., BOA NOVA, A.C. e ZYLBERSTAJN, David. Social and political aspects of a biomass-origin cogeneration program. The Brazilian experience. In: $X$ European Conference - biomass of energy industry. Junho, 1998.

COELHO, Suani T. e MERCEDES, Sonia S. P. Brazilian policy for greenhouse gas mitigation: the national reference Center on Biomass - CENBIO. In: II EETIC Teams Meeting. Novembro, 1998.

COELHO, S. T.; OLIVEIRA JUNIOR, S.; ZYLBERSZTAJN, D. Análise Termoeconômica da Cogeração de Eletricidade a partir do Bagaço de Cana. Estudo de Caso para uma Usina no Estado de São Paulo. In: XIV COBEM - Congresso Brasileiro de Engenharia Mecânica. Bauru, 1997.

COELHO, S. T.; OLIVEIRA JUNIOR, S.; ZYLBERSZTAJN, D. Thermoeconomic Analysis of Electricity Cogeneration from Sugarcane Origin. In: Third Biomass Conference Of The Americas. Montreal, 1997. v. 2. p. 1631-1640.

FERREIRA, Maria Julita Guerra; ANDRADE, Adnei Melges de. Sistemas Fotovoltaicos em Escolas Rurais: a experiência do PRODEEM - São Paulo. In: IV Encontro de Energia no Meio Rural - AGRENER /UNICAMP. Campinas, 2002.

FERREIRA, Maria Julita Guerra; CAMPOS, Ubirajara Sampaio de. Instalações Fotovoltaicas do PRODEEM - São Paulo e Uma Proposta de Organização Regional. In: VIII Congresso Brasileiro de Energia. Rio de Janeiro, 2000.

FERREIRA, Maria Julita Guerra; ZILLES, Roberto; SHALDERS NETO, Armando. A Eletrificação Fotovoltaica e a Necessidade de Treinamento. In: III Encontro de Energia no Meio Rural-AGRENER/UNICAMP. Campinas, 2000.

FERREIRA, Maria Julita Guerra. Eletrificação Rural, Renováveis e o Resgate da Cidadania. In: Workshop Sobre Energia e Desenvolvimento Sustentável. Rio de Janeiro, 1997.

FEDRIZZI, M. C.; SAUER, Ildo Luis. Bombeamento solar fotovoltaico, histórico, características e projeto. In: IV Encontro de Energia no Meio Rural AGRENER/UNICAMP. Campinas, 2002.

FEDRIZZI, M. C.; SAUER, Ildo Luis; LORENZO, Eduardo. What is wrong with those PV pumping systems in Brazil? In: VII World Renewable Energy Congress. Colonia 2002.

FEDRIZZI, M. C.; SAUER, Ildo Luis. Simple and useful instrumentation to determine the performance of PV pumping systems in the field. In: 17th European Photovoltaic Energy Conference. Munique, 2001.

FEDRIZZI, M. C.; ZILLES, Roberto; TRIGOSO, Federico Morante. Avaliação dos sistemas fotovoltaicos instalados nas residências dos moradores da Ilha do Cardoso. In: III Encontro de Energia no Meio Rural AGRENER/UNICAMP. Campinas, 2000. 
FEDRIZZI, M. C.; SAUER, Ildo Luis; NODA, Hiroshi. Sistemas de bombeamento fotovoltaico de uso comunitário: implantação em comunidades isoladas na Amazônia. In: III Encontro de Energia no Meio Rural AGRENER/UNICAMP. Campinas, 2000.

FEDRIZZI, M. C.; ZILLES, Roberto; NODA, Hiroshi. PV systems implementation experience in the Brasilian Amazon rain forest. In: VI World Renewable Energy Congress (UNESCO). Brighton, 2000.

FEDRIZZI, M. C.; ZILLES, Roberto; TRIGOSO, Federico Morante. Ecowatt program's technical evaluation and user's satisfaction. In: 16th European Photovoltaic Solar Energy Conference. v. III., Glasgow, 2000, p. 2896-2899.

FEDRIZZI, M. C.; SERPA, Paulo. Sistemas Fotovoltaicos para o Abastecimento de Água: Uma Experiência de Adoção da Tecnologia em Comunidades Tradicionais. In: VIII Congresso Brasileiro de Energia. v. 3, Rio de Janeiro:UFRJ, 1999, p. 1227-1230.

FEDRIZZI, M. C.; SAUER, Ildo Luis. Pequenos Sistemas de Bombeamento Fotovoltaico, Análise da Competitividade com outras Opções. In: III Congresso de Planejamento Energético. São Paulo, 1998.

FEDRIZZI, M. C.; ZILLES, Roberto. Treinamento Técnico Local aos Usuários de Pequenos Sistemas Fotovoltaicos. In: IV Encontro do Foro Permanente de Energias Renováveis. Recife, 1998.

OLIVEIRA, S. H. F.; ZILLES, R.. Why do we need rules and standards to implement grid-connected distributed PV systems in Brazil?. In: IEEE/PES Transmition \& Distribution 2002 Latin America Conference. São Paulo: Sonopress, 2002.

OLIVEIRA, S. H. F.; ZILLES, R. Distributed Power Generation with Photovoltaic Systems at USP. In: IEEE/PES Transmition \& Distribution 2002 Latin America Conference. São Paulo: Sonopress, 2002.

OLIVEIRA, S. H. F.; ZILLES, R. 6.3kWp Photovoltaic Building Integration at São Paulo University. In: 17th European Photovoltaic Solar Energy Conference. München, 2001.

OLIVEIRA, S. H. F.; ZILLES, R. Índices de Mérito e o Comportamento do Sistema Fotovoltaico Instalado no LSF - IEE/USP. In: VIII Congresso Brasileiro de Energia. v.3, Rio de Janeiro: COPPE/UFRJ, 1999, p. 1381-1389.

OLIVEIRA, S. H. F.; ZILLES, R. O Preço do Wp e o Custo do kWh Fornecido por Sistemas Interligados à Rede Elétrica. In: VIII Congresso Brasileiro de Energia. v.3, Rio de Janeiro: COPPE/UFRJ, 1999 p. 743-748.

OLIVEIRA, S. H. F.; ZILLES, R. Pequenos Geradores Fotovoltaicos Conectados à Rede de Distribuição de Eletricidade. In: III Congresso Brasileiro de Planejamento Energético. São Paulo, 1998.

OLIVEIRA, S. H. F.; ZILLES, R. Dimensionamiento de Sistemas Fotovoltaicos Autónomos: Enfasis en la Eletrificación de Viviendas de Bajo Consumo. In: II Seminário Internacional de Energías Renovables. v. 1, Cochabamba : CINER, 1997. p. 87-99.

SAUER, Ildo Luis; SANTOS, Rosana Rodrigues; MERCEDES, Sônia Seger. A reestruturação do setor elétrico brasileiro e a universalização do acesso ao serviço de energia elétrica. In: Anais do Congresso Brasileiro de Energia - CBE. Rio de Janeiro: 
Sociedade Brasileira de Planejamento Energético/COPPE-UFRJ/Clube de Engenharia, 1999. pp. 680-706

SERPA, Paulo; ZILLES, R. Avaliação da Difusão de Sistemas Fotovoltaicos Domiciliares em Comunidades Tradicionais. In: IV Encontro de Energia no Meio Rural - AGRENER/UNICAMP. Campinas, 2002.

SERPA, Paulo; FEDRIZZI, M. C. Sistemas Fotovoltaicos para o Abastecimento de Água: Uma Experiência de Adoção da Tecnologia em Comunidades Tradicionais. In: VIII Congresso Brasileiro de Energia-CBE. v. III, Rio de Janeiro: Chivas Produções, 1999. p. 1227-1231.

VELÁZQUEZ, S. G; COELHO, S. T. \& ZYLBERSZTAJN, D. Cogeneration in brazilian pulp and paper industry from biomass-origin to reduce $\mathrm{CO}_{2}$ emissions. In: Developments in thermo-chemical biomass conversion. Canadá, Vol. III, maio, 1996. pp. 1073-1085.

ZILLES, Roberto; ANDRADE, Adnei Melges; PRADO Jr., Fernando Amaral do. Solar home system programs in São Paulo State, Brasil: utility and user associations experiences. In: XIV European Photovoltaic Solar Energy Conference. Barcelona: Espanha, Junho, 1997.

ZILLES, Roberto e OLIVEIRA, Sergio H. F. Pequenos geradores fotovoltaicos conectados à rede de distribuição de eletricidade. In: III Congresso Brasileiro de Planejamento Energético. São Paulo: Sociedade Brasileira de Planejamento Energético, 1998.

ZYLBERSTAJN, David e COELHO, Suani Teixeira. A preliminary analysis of mechanisms to improve biomass-origin co-generation in Brazil. In: $9^{\text {th }}$ European Bioenergy Conference. Copenhagen/Dinamarca: Elsevier Science Ltd. Junho, 1996.

ZYLBERSZTAJN, David; IENO, Gilberto O.; COELHO, Suani Teixeira. Biomass in Amazonia and electricity generation. In: I Seminário Internacional de Energias Renovables. Bolivia, setembro, 1994.

ZYLBERSZTAJN, David; IENO, Gilberto O.; COELHO, Suani Teixeira. Electricity production in Amazonia from biomass crops residues. In: Biomass for Energy, Environment, Agriculture and Industry. Viena/Austria, outubro, 1994.

\section{BIBLIOGRAFIA}

A ENERGIA ELÉTRICA NO BRASIL: DA PRIMEIRA LÂMPADA À ELETROBRÁS. Rio de Janeiro: Biblioteca do Exército, 1977.

ABRANTES, Paulo César Coelho. Imagens de natureza, imagens de ciência. Campinas: Papirus, 1998.

ALDABÓ, Ricardo. Energia solar. São Paulo: Artliber Editora, 2002.

ALMEIDA, Jozimar Paes de. A extinção do arco-íris: ecologia e história. Campinas: Ed. Papirus, 1988. 
EDUEL, 1996.

. Errante no campo da razão: o inédito na história. Londrina:

. Biodiesel o "Óleo Filosofal": desafios para a educação ambiental

no caldeirão do "Desenvolvimento Sustentável". Londrina/Pr: Atrito Art Editorial, 2007.

ALTVATER, Elmar. O preço da riqueza: pilhagem ambiental e a nova (des)ordem mundial. São Paulo: Editora da Universidade Estadual Paulista, 1995.

ALVARENGA, Augusta Thereza de; SOMMERMAN, Américo; ALVAREZ, Aparecida Magali de Souza. Congressos internacionais sobre transdisciplinaridade: reflexões sobre emergências e convergências de idéias e ideais na direção de uma nova ciência moderna. In: Saúde \& Sociedade. [online]. vol. 14, no. 3, 2005.

ALVES, Rubem. Filosofia da ciência: introdução ao jogo e suas regras. São Paulo: Edições Loyola, 2000.

ASIMOV, Isaac. Vida e Energia. São Paulo: Bestseller Importadora de Livros S/A, 1965.

BARROS, José D'Assunção. O campo da história: especialidades e abordagens. Petrópolis/RJ: Vozes, 2004.

BARTOLETTO, Silvana. L'approvvigionamento energético della citá di Napoli tra XIX e XX secolo. IN: ZILLI, Ilana (Org.) La natura e la cittá per uma storia ambientale di Napoli fra '800 e '900. Napoli: Edizioni Scientifiche Italiane, 2004. pp. 139-175.

BECKER, Dinizar F. Desenvolvimento sustentável: necessidade elou possibilidade? Santa Cruz do Sul: EDUNISC, 2002.

BERMANN, Célio. Energia no Brasil: para quê? para quem? Crise e alternativas para um país sustentável. São Paulo: Editora da Livraria da Física/FASE, 2001.

BLACKBURN, Richard J. O vampiro da razão. São Paulo: Ed. Unesp, 1992.

BLOCH, Marc. Apologia da Historia, ou, O Oficio do Historiador. Rio de Janeiro: Jorge Zahar, 2001.

BODEI, Remo. A História tem um sentido? Bauru, S.P: Editora da Universidade do Sagrado Coração, 1997.

BOSQUET, Michel (André Gorz). Ecologia e liberdade. Lisboa: Ed. Veja, 1978.

BRASIL (Presidência da República). Comissão Interministerial para Preparação da Conferencia das Nações Unidas sobre Meio Ambiente e Desenvolvimento. O desafio do desenvolvimento sustentável. Brasília: Cima, 1991.

BRAUDEL, Fernand. Escritos sobre a História. São Paulo: Perspectiva, 2005.

BROWN, Lester (org.). Worldwatch Institute. Qualidade de vida: salve o planeta! São Paulo: Globo, 1993.

BUARQUE, Cristovam. A desordem do progresso: o fim da era dos economistas e a construção do futuro. Rio de Janeiro: Paz e Terra, 1990.

BURSZTYN, Marcel. Ciência, ética e sustentabilidade. São Paulo: Cortez; Brasília, DF: UNESCO, 2001. 
CALABI, André Sandro et al. A energia e a economia brasileira: interações econômicas e institucionais no desenvolvimento do setor energético no Brasil. São Paulo: Pioneira: Fundação Instituto de Pesquisas Econômicas, 1983.

CÂMARA DOS DEPUTADOS. Colapso energético no Brasil e alternativas futuras. Brasília: Câmara dos Deputados/Coordenação de Publicações, 2001.

CÂMARA DOS DEPUTADOS. Desenvolvimento e importância da tecnologia nacional. Brasília: Centro de Documentação e Informação/Coordenação de Publicações, 1978.

CAMARGO, Aspásia; CAPOBIANCO, João Paulo Ribeiro; OLIVEIRA, José Antonio Puppim de (Orgs). Meio ambiente Brasil: avanços e obstáculos pós Rio 92. São Paulo/Rio de Janeiro. Estação Liberdade; Instituto Sócio Ambiental/Fundação Getúlio Vargas, 2002.

CAPRA, Fritjof. O Tao da física: um paralelo entre a física moderna e o misticismo oriental. São Paulo: Cultrix, 2000.

São Paulo: Cultrix, 1998.

. O ponto de mutação: a ciência, a sociedade e a cultura emergente.

CARDOSO, Fernando Henrique. Perspectivas de desenvolvimento e meio ambiente: o caso do Brasil. In: Encontros com a Civilização Brasileira. V. 20, 1979.

CASTORIADIS, C. A instituição imaginaria da sociedade. Rio de Janeiro: Ed. Paz e Terra, 1982.

CASTORIADIS, C.; COHN-BENDIT, D. Da ecologia à autonomia. São Paulo, Ed. Brasiliense, 1981.

CHALMERS, Alan F. A fabricação da ciência. São Paulo: EDUNESP, 1994.

CLASTRES, Pierre. A sociedade contra o estado. Rio de Janeiro: Francisco Alves, 1978.

COLACIOS, Roger D. Construindo as Ciências: Bruno Latour e as estratégias da literatura científica. IN: Anais do Encontro Regional de História/Anpuh-Pr. Maio, 2008.

. Matriz energética brasileira: consolidação, expansão, políticas e meio ambiente (1971-1979). In: Revista Territórios e Fronteiras V.2, N.1, pp 242-262, Jan/Jun 2009.

COLLINS, Harry e PINCH, Trevor. O golem: o que você deveria saber sobre ciência. São Paulo: Editora UNESP, 2003.

COMMONER, Barry. Energias Alternativas. Rio de Janeiro: Editora Record, 1986.

COMISSÃO DE DESENVOLVIMENTO E MEIO AMBIENTE DA AMÉRICA

LATINA E CARIBE. Nossa própria agenda. Banco Interamericano de Desenvolvimento: Programa das Nações Unidas para o Desenvolvimento. 1989.

COMISSÃO MUNDIAL sobre MEIO AMBIENTE e DESENVOLVIMENTO. Nosso futuro comum. Rio de Janeiro: Editora da Fundação Getulio Vargas, 1988.

CONANT, Melvin A.; GOLD, Fern Racine. A geopolítica energética. Rio de Janeiro: Atlântida, 1981. 
CONFERÊNCIA DAS NAÇÕES UNIDAS SOBRE MEIO AMBIENTE E DESENVOLVIMENTO. Agenda 21. 3ed. Brasília: Senado Federal, Subsecretaria de Edições Técnicas, 2003.

CROSBY, Alfred W. Imperialismo ecológico: a expansão biológica da Europa (900 1900). São Paulo: Companhia das Letras, 1993.

CÚPULA MUNDIAL SOBRE DESENVOLVIMENTO SUSTENTÁVEL. Relatório da delegação do Brasil. Brasília: Fundação Alexandre de Gusmão, 2004.

DE ANGRA A ARAMAR: OS MILITARES A CAMINHO DA BOMBA. s/d.

DELÉAGE, Jean Paul. Historia de la Ecologia. Barcelona/Espanha: Icaria Editorial, 1993.

DICIONÁRIO ENCICLOPÉDICO KOOGAN, LAROUSSE, SELEÇÕES. Rio de Janeiro: Editora Larousse do Brasil Ltda., 1982. Vol. 1.

DIEGUES, Antonio Carlos. O mito moderno da natureza intocada. São Paulo: HUCITEC; Núcleo de Apoio à Pesquisa sobre Populações Humanas e Áreas Úmidas Brasileiras, USP, 2004.

DRAY, William. Filosofia da História. Rio de Janeiro: Zahar Editores, 1977.

DRUMMOND, José Augusto. A História ambiental: temas, fontes e linhas de pesquisa. In: Revista estudos históricos, vol. 4, n. 8, Rio de Janeiro, 1991.

DUARTE, Regina Horta. História e natureza. Belo Horizonte: Autêntica, 2005.

FEBVRE, Lucien. Le problème de l'incroyance au XVIe siècle, la religion de Rabelais. Paris: Reedição Albin Michel, 1968. p. 12.

FEYERABEND, Paul. Contra o método. São Paulo: Editora UNESP, 2007.

FIGUEIREDO, Betânia G.; CONDÉ, Mauro Lúcio L. Ciência, história e teoria. Belo Horizonte: Argvmentvm Editora, 2005.

FLECK, Ludwik. Genesis and development of a scientific fact. Chigago: The University of Chicago Press, 1981.

FOLHA ONLINE. Físico da USP ganha prêmio de $R \$ 800$ mil. Disponível em www.folhaonline.com.br .Acessado em 20/06/2008.

FONSECA, Francisco F. A. O mundo em crise: economia, ecologia e energia. São Paulo: Signus Editora, 1999.

FOUCAULT, Michel. A ordem do discurso. São Paulo: Edições Loyola, 1996. . Arqueologia do Saber. Rio de Janeiro: Forense Universitária, 2007. . As palavras e as coisas. São Paulo: Martins Fontes, 2007.

FOUREZ, Gérard. A construção das ciências: introdução a filosofia e à ética das ciências. São Paulo: Editora da Universidade Estadual Paulista, 1995.

FRANCO JR. Hilário. Cocanha: a história de um país imaginário. São Paulo: Companhia das Letras, 1998.

GAMA, Ruy. Ciência e técnica: antologia de textos históricos. São Paulo: T.A Queiroz, Editor Ltda., 1993.

GARDINER, Patrick. Teorias da História. Lisboa: Calouste Julbentman, 1988. 
GONÇALVES, Carlos W. P. Paixão da terra: ensaios críticos de ecologia e geografia. Rio de Janeiro: Ed. Rocco, 1984.

. Os (des)caminhos do meio ambiente. São Paulo: Contexto, 1998. . O desafio Ambiental. Rio de Janeiro: Editora Record, 2004.

GRANGER, Gilles-Gaston. A ciência e as ciências. São Paulo: Editora UNESP, 1994.

HALACY, Daniel S. La nueva era de la energia solar. Buenos Aires: Argentina: Marymar Ediciones, 1975.

HAMBURGUER, Amélia Império; DANTES, Maria Amélia; PATY, Michel; PETITJEAN, Patrick (Orgs). A ciência nas relações Brasil-França (1850-1950). São Paulo: EDUSP: FAPESP, 1996.

HELLER, Agnes. Uma teoria da História. Rio de Janeiro: Civilização Brasileira, 1993.

HOBSBAWM, Eric J. A Era do Capital. Rio de Janeiro: Paz e Terra, 1996.

2000. . A era das revoluções: 1789 - 1848. São Paulo: Ed. Paz e Terra,

HORKHEIMER, Max; ADORNO, Theodor. O Conceito de Iluminismo. In: Textos Escolhidos. São Paulo: Nova Cultural, 1999.

INSTITUTO SÓCIOAMBIENTAL. Almanaque socioambiental. São Paulo, 2005.

JANNUZZI, Gilberto De Martino. Políticas públicas para eficiência energética e renovável no novo contexto de mercado: uma análise da experiência recente dos EUA e do Brasil. Campinas: Autores Associados, 2000.

JENKINS, Keith. A História repensada. São Paulo: Contexto, 2004.

JORGE, Janes. Tietê, o rio que a cidade perdeu: o Tietê em São Paulo (1890-1940). São Paulo: Alameda, 2006.

KOSELLECK, Reinhart. Futuro passado: contribuição à semântica dos tempos históricos. Rio de Janeiro: Contraponto/PUC Rio, 2006.

KUHN, Thomas. A estrutura das revoluções científicas. São Paulo: Perspectiva, 2006.

LACERDA, Celso Juarez (Coord.) Ciência e tecnologia: um desafio permanente. Rio de Janeiro: ADESG, 1984.

LATOUR, Bruno; WOOLGAR, Steve. A vida de laboratório: a produção dos fatos cientificos. Rio de Janeiro: Relume Dumará, 1997.

LATOUR, Bruno. Jamais fomos modernos: ensaio de antropologia simétrica. Rio de Janeiro: Ed. 34, 1994.

EDUSC, 2004.

. Politicas da natureza: como fazer ciência na democracia. Bauru:

A esperança de Pandora: ensaios sobre a realidade dos estudos cientificos. Bauru: EDUSC, 2001.

Ciência em ação: como seguir cientistas e engenheiros sociedade afora. São Paulo: Editora UNESP, 2000.

Joliot: a história e a física misturadas. In: SERRES, Michel (Dir.)

Elementos para uma História das Ciências. Lisboa: Terramar,2003. 
. Give me a laboratory and I will raise the world. In: KNORRCETINA, Karin D.; MULKAY, Michael. Science Observed: perspectives on the social study of science. London: Sage Publications, s/d.

LAUDAN, Larry et al. Mudança científica: modelos filosóficos e pesquisa histórica. In: Estudos Avançados, ano 7, número 19, 1993.

LEFF, Enrique. Aventuras da epistemologia ambiental: da articulação das ciências ao diálogo de saberes. Rio de Janeiro: Garamond, 2004.

LE GOFF, Jacques. História e memória. Campinas: Ed. da Unicamp, 1996.

LÉVY-LEBLOND, Jean-Marc. O pensar e a prática da ciência: antinomias da razão. Bauru: EDUSC, 2004.

LOWITH, Karl. O sentido da História. Lisboa: Ed. 70, 1991.

LUCIANI, Giacomo. A OPEP na economia mundial. In: Encontros com a Civilização Brasileira. N. 16, out, 1979.

MALERBA, Jurandir (Org.) A velha História: teoria, método e historiografia. Campinas: Papirus, 1996.

MANNERS, Gerald. Geografia da Energia. São Paulo: Zahar Editores, 1976.

MARTIN, Jean-Marie. A economia mundial de energia. São Paulo: EDUNESP, 1992.

MARTINEZ, Paulo H. (Org.) História ambiental paulista: temas, fontes, métodos. São Paulo: Editora SENAC São Paulo, 2007. . História ambiental no Brasil: pesquisa e ensino. São Paulo: Cortez, 2006.

MEADOWS, Dennis L. Et. Al.. Limites do crescimento. São Paulo: Perspectiva, 1973.

MELO, Fernando Homem de; FONSECA, Eduardo Giannetti da. Proálcool, energia e transportes. São Paulo: Pioneira; FIPE, 1981.

MORAES, Antonio Carlos Robert. Meio ambiente e ciências humanas. São Paulo: Hucitec, 1994.

MOREIRA, Helena Margarido; GIOMETTI, Analúcia B. dos Reis. O Protocolo de Quioto e as possibilidades de Inserção do Brasil no Mecanismo de Desenvolvimento Limpo por meio de Projetos em Energia Limpa. In: Contexto Internacional. Rio de Janeiro, vol. 30, n. 1, janeiro/abril, 2008. pp. 9-47.

MOREL, Regina Lúcia de Moraes. Ciência e Estado: a política científica no Brasil. São Paulo: T. A. Queiroz, 1979.

MORIN, Edgar. O Método I: a natureza da natureza. Portugal: Publicações EuropaAmérica, 1977.

MORIN, Edgar; WULF, Christoph. Planeta: a aventura desconhecida. São Paulo: EDUNESP, 2003.

MORIN, Edgar; KERN, Anne Brigitte. Terra-Pátria. Porto Alegre: Sulina, 2003.

MOSCOVICI, Serge. Sociedade contra a natureza. Rio de Janeiro: Editora Vozes, 1975. 
Instituto Gaia, 2007.

. Natureza: para a pensar a ecologia. Rio de Janeiro: Mauad X:

MOTOYAMA, Shozo (Org) Tecnologia e industrialização no Brasil: uma perspectiva histórica. São Paulo: EDUNESP/Centro Estadual de Educação Tecnológica Paula Souza, 1994.

MOURÃO, Ronaldo Rogério de Freitas. Sol e energia no terceiro milênio. São Paulo: Scipione, 2000.

MULLER, Geraldo. Desenvolvimento sustentável. Notas para a elaboração de um esquema de referência. In: BECKER, Dinizar Fermiano (Org.). Desenvolvimento sustentável: necessidade e/ou possibilidade? 4o. ed. rev. e amp. Santa Cruz do Sul, Edunisc, 2002. pp. 117-138.

NISBET, Robert. História da idéia de progresso. Brasília: Editora Universidade de Brasília, 1985.

NOVAES, Adauto (Org). Tempo e História. São Paulo: Cia das Letras, 1992.

NOVAES, Washington. A década do impasse da Rio 92 a Rio + 10. São Paulo, Estação Liberdade; Instituto Sócioambiental, 2002.

OLIVEIRA, P. M. C.; DECHOUM, K. Facilitando a Compreensão da Segunda Lei da Termodinâmica. In: Revista Brasileira de Ensino de Física, Vol. 25, no. 4, dezembro, 2003.

OPIE, John. Nature's nation: an environmental history of the United States. Orlando/Florida: Harcourt Brace \& Company, 1998.

PEIXOTO, João B. O desafio da crise energética. Rio de Janeiro: CAPEMI, 1981.

PEYRET, Henry. A batalha pela energia. São Paulo: Difusão Européia do Livro, 1961.

PESSIS-PASTERNAK, Guitta. A ciência: deus ou diabo? São Paulo: Editora UNESP, 2001.

PESTRE, Dominique. Por uma nova História Social e Cultural das ciências: novas definições, novos objetos, novas abordagens. In: Cadernos IG/UNICAMP, vol. 6, número 1, 1996.

PHILLIPSON, John. Ecologia Energética. São Paulo: Editora Nacional, 1977.

PIETRE, Valdir. Proálcool: legislação, ecologia e questão social. In: Encontros com a Civilização Brasileira. V. 26, 1980. pp. 59-78

POMBO, Olga. Práticas interdisciplinares. In: Sociologias [online]. no. 15, 2006.

PRIGOGINE, Ilya. As leis do caos. São Paulo: Editora UNESP, 2002.

Editora UNESP, 1996.

O fim das certezas: tempo, caos e as leis da natureza. São Paulo:

REIGOTA, Marcos. Meio ambiente e representação social. São Paulo: Cortez, 1998.

RODRIGUES, Eduardo Celestino. Crise Energética. Rio de Janeiro: J. Olympio, 1975.

RONAN, Colin A. Da Renascença a Revolução Cientifica. História ilustrada da ciência. Universidade de Cambridge. 4 Vols. São Paulo: Circulo do Livro, 1987. 
ROJAS, Carlos Antonio Aguirre. Tempo, duração e civilização: percursos braudelianos. São Paulo: Cortez, 2001.

ROSA, Claudia Beltrão da. Da utilidade de uma história "histórica" da ciência. In: Morpheus - Revista Eletrônica em Ciências Humanas, ano 02, número 02, 2003.

ROSA, Luis Pinguelli. Evolução da Política Nuclear Brasileira. In: Encontros com a Civilização Brasileira. V. 07, 1979.

2001.

. O apagão: por que veio? Como sair dele? Rio de Janeiro: REVAN,

ROSSET, Clément. A Antinatureza: elementos para uma filosofia trágica. Rio de Janeiro: Espaço e Tempo, 1989.

SACHS, Ignacy. Estratégias de transição para o século XXI: desenvolvimento e meio ambiente. São Paulo: Studio Nobel: Fundação do desenvolvimento administrativo, 1993.

SAGAN, Carl. Os dragões do Éden. Rio de Janeiro: Francisco Alves, 1987.

SAGASTI, Francisco R. Tecnologia, Planejamento e Desenvolvimento Autônomo. São Paulo: Editora Perspectiva, 1986.

SANTOS, Boaventura de Sousa (Org.) Conhecimento prudente para uma vida decente. São Paulo: Cortez, 2004.

SCHAEFFER, Francis A. Pollution and the Death of Man. Illinois, 1973.

SCHPS, Ruth. O império das técnicas. Campinas/São Paulo: Papirus, 1996.

SCHUMACHER, E. F. O negócio é ser pequeno (small is beautiful): um estudo de Economia que leva em conta as pessoas. Rio de Janeiro: Zahar Editores, 1981.

SCHWARTZMAN, Simon. Ciência e História da Ciência. In: FINEP, Grupo de Estudos sobre o Desenvolvimento da Ciência, Documento de Trabalho. n. 2, 1976.

SCOTTO, Gabriela Et. Al.. Desenvolvimento sustentável. Petropólis/Rio de Janeiro: Editora Vozes, 2007.

SIMONNET, Dominique. O ecologismo. Lisboa: Moraes Editores, 1981.

SOUZA, Heitor G. de, e outros. Política Cientifica. São Paulo: Editora Perspectiva, 1972.

STENGERS, Isabelle. A invenção das ciências modernas. São Paulo: Editora 34, 2002.

TARADE, Guy. O livro negro da poluição. Lisboa: Bertrand, 1980.

THOMPSON, Kevin. Historicity and transcendentality: Foucault, Cavaillès, and the phenomenology of the concept. In: History and Theory, Wesleyan University, n. 47, pp. 1-18, Feb., 2008.

TIEZZI, Enzo. Tempos históricos, tempos biológicos. A Terra ou a morte: os problemas da nova ecologia. São Paulo: Nobel, 1988.

VARGAS, Paulo Rogério. O insustentável discurso da sustentabilidade. In: BECKER, Dinizar Fermiano (Org.). Desenvolvimento sustentável: necessidade elou possibilidade? 4o. ed. rev. e amp. Santa Cruz do Sul, Edunisc, 2002. pp. 207-

VERNE, Julio. Paris no século XX. São Paulo: Editora Ática, 1995. 
WARD, Bárbara; DUBOS, René. Uma terra somente: a preservação de um pequeno planeta. São Paulo: Edgar Blucher/Melhoramentos/Ed. da Universidade de São Paulo, 1973.

WILLIANS, Henry Smith. A History of Science. 4 Vols. Illinois/EUA: Project Gutenberg Etext, Abril, 1999.

WILLRICH, Mason. Energia e política mundial. Rio de Janeiro: Agir, 1978.

WORSTER, Donald. Para fazer história ambiental. In: Estudos Históricos, Rio de Janeiro: vol. 4 (8), 1991. 